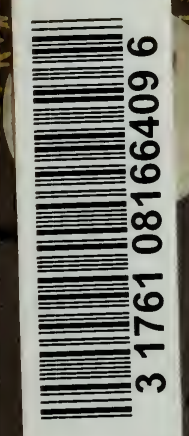

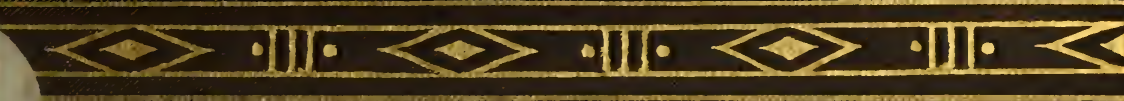

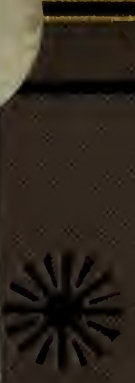







\section{OLD NEW ZEALAND,}

A TALE OF THE GOOD OLD TIMES;

$$
\text { AND }
$$

A HISTORY OF THE WAR IN THE

NORTH AGAINST THE CHIEF

HEKE, IN THE YEAR

1845.

TOLD BY AN OLD CHIEF OF THE NGAPUHI TRIBE.

BY A PAKEHA MAORI.

WITH AN INTRODLCTION

BY THE EARL OF PEMBROKE.

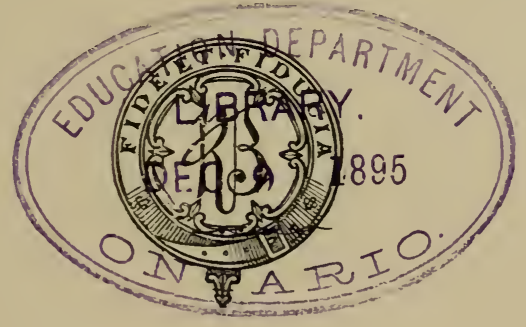

L O NDON :

RICHARD BENTLEY AND SON, 19ubtishers in Orjinate to mer NEW BURLINGTON STREET. 1884. 


$$
\begin{aligned}
& D 4 \\
& 411 \\
& M_{35} \\
& 1884 \\
& \operatorname{cog} 3
\end{aligned}
$$

CHISWICK PRESS :-C. WHITTINGHAM AND CO., TOOKS COURT 

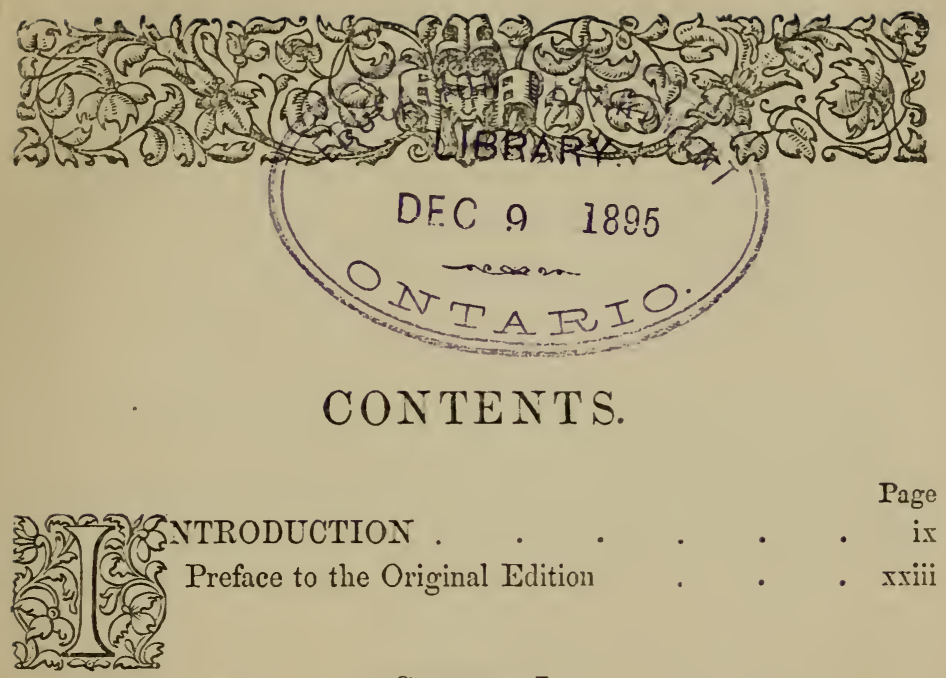

Chapter I.

Introductory-First, View of New Zealand-First Sight of the Natives, and First Sensations experienced by a mere Pakeha-A Maori Chief's notions of trading in the Old Times -A dissertation on "Courage"-A few words on Dress-The Chief's Soliloquy-The Maori Cry of Welcome . .

Cinapter II.

The Market Price of a Pakcha-The value of a Pakeha " as such"-Maori Hospitality in the Good Old Times-A Respectable Friend-Maori Mermaids-My Notions of the value of Gold-How I got on Shore . . . . .

\section{Chapter III.}

A Wrestling Match-Beef against Melons-The Victor gains a loss-" Our Chief"-His Speech-His status in the Tribe-Death of "Melons"-Rumours of Peace and WarGetting the $\mathrm{Pa}$ in fighting order-My Friend the "Relation Eater"-Expectation and Preparation-Arrival of Doubtful Friends-Sham Fight_The "Taki"-The War DanceAnother Example of Maori Hospitality-Crocodile's Tears- 
Loose Notions about Heads-Tears of Blood-Brotherly Love-

\section{Chapter IV.}

A Little affair of " Flotsam and Jetsam "-Rebellion Crushed in the Bud-A Pakeha's House Sacked-Maori Law-A Maori Lawsuit-Affairs thrown into Chancery . • .

\section{Chapter V.}

Every Englishman's House is his Castle-My Estate and Castle-How I purchased my Estate-Native Titles to Land, of what Nature-Value of Land in New Zealand-Land Commissioners-The Triumphs of Eloquence-Magna Charta .

\section{Chapter VI.}

How I kept House-Maori Freebooters-An Ugly Customer-The "Suaviter in Modo"-A single Combat to amuse the Ladies-The true Maori Gentleman-Character of the Maori People • • • • • • • .

\section{Chapter Vil.}

Excitement caused by first Contact with Europeans-The Two Great Institutions of Maori Land-The Muru-The Tapu-Instances of Legal Robbery-Descriptions and Examples of the Muru-Profit and Loss-Explanation of some of the Workings of the Law of Muru . . • .

\section{Chapter ViII.}

The Muru falling into Disuse-Why-Examples of the Tapu-The Personal Tapu-Evading the Tapu-The Undertaker's Tapu-How I got Tabooed-Frightful DifficultiesHow I got ont of them-The War Tapu-Maori War Customs.

\section{Chapter IX.}

The Tapu Tohunga-The Maori Oracle-Responses of the Oracle-Priestcraft 
Chapter $\mathrm{X}$.

The Priest erokes a Spirit-The Consequences-A Maori Page Tragedy-The "Tohunga" again . . . . .

\section{Chapter XI.}

The Local Tapu-The Taniwha-The Battle on MotitiDeath of Tiki Whenua-Reflections-Brutus, Marcus Antonius, and Tiki Whenua-Suicide . . . . . .

\section{Chapter XiI.}

The Tapa - Instances of - The Storming of Mokoia Pomare-Hongi Ika-Tareha-Honour amongst Thieves

\section{Chapter XiII.}

" My Rangatira"-The respective Duties of the Pakeha and his Rangatira-Public Opinion-A "Pakeha Kino"-Description of my Rangatira-His Exploits and Misadrentures-His Moral Principles-Decline in the numbers of the NatiresProofs of former Large Population-Ancient Forts-Causes of Decrease . . . . . . . . .

\section{Chapter XIV}

Trading in the Old Times-The Native Difficulty-Virtue its own Reward-Rule Britannia-Death of my Chief-His Dying Speech-Rescue-How the World goes Round . . 165

\section{Chapter $\mathrm{NV}$.}

Mana-Foung New Zealand-The Law of England_- " Pop goes the weasel"-Right if we have Might-God save the Queen-Good Advice . . . . . . . 174

History of the War in the Tortil of New Zealand against the Chief Here . . . . . 



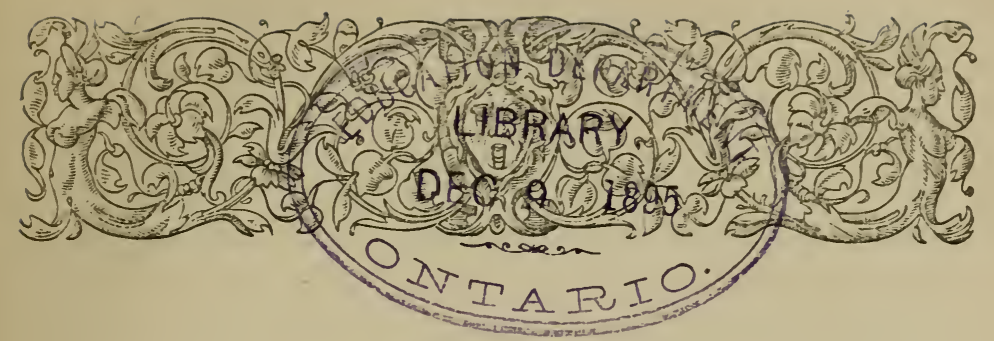

\section{INTRODUCTION.}

Colonization (I like to be particular
and simple policy in regard to the savage races with whom they came in contact, which may be roughly described as going their own way, and punishing the natives if they didn't conform to it, without troubling themselves much about what the aforesaid natives thought or felt on the subject. If they understood the meaning of it so much the better for them, if they did not it could not be helped. Holding themselves to be morally and intellectually far superior to the sarages, they maintained that it was the sarage's business to understand and conform to their notions, and not their business to regard the savage's. As for giving sarages the rights of civilized men it was seldom thought of; savages were to be treated as such.

I do not exactly know when this sort of native policy was first practised, but I know that it has 
lasted, with modifications, even to our day, and is to be seen in full working order in more than one part of the globe.

And let me remark (pace the Philanthropists) that it is not always the unwisest or cruellest policy that can be followed, for this reason, that it is simple, consistent, and easily understood. The man or the nation that consistently follows its own path, turning aside for no consideration, soon becomes at least thoroughly known if not intelligently understood. And misconceptions and misunderstandings are the most fruitful of all causes of bloodshed between civilized and savage races.

Let me confess, moreover, that there have been moments when I have felt certain carnal hankerings after that same old native policy. When, for instance, I had just left the French colony of New Caledonia, where amicable relations with the natives were preserved, and the country made as safe as Italy from end to end by the simple expedient of regularly and invariably executing a certain number of natives for every white man that they disposed of, without much inquiry into the motives of the murderers; and had returned to New Zealand to hear of a most lively massacre at Poverty Bay, perpetrated by three hundred Maori gentlemen, very well up in their Old Testaments and extremely practical in the use of the New, ${ }^{1}$ who having satisfied the more pressing de-

1 They made cartridges of them. These were the Hau Haus, a sect of Maories who, when the prestige of Christianity first 
mands of their appetite upon the field of their exploit, had shown the sacred light of civilization that was burning within them by potting the remainder of the corpses in tins and sending them as presents to their friends in the country, and had then departed to the mountains, filled with the comfortable conviction that nothing worse than imprisonment would follow the improbable event of their capture, that after a year or two of most enjoyable skirmishing the matter would be allowed to drop, and that they would most of them go to their graves well-honoured and unhung. ${ }^{1}$

began to wane in the native mind, abolished the New Testament, retained the Old, which was more to their taste, and by mixing with it a large quantity of their old heathenism, produced a religion entirely deroted theoretically and practically to plunder and blood.

1 I regret to say that the strict propriety (according to the received code of that day) with which the Poverty-Bay massacre, and the fighting which followed it, were prosecuted on both sides, was marred by the scandalous behaviour of a settler whose name I forget; this man's wife and child were mutilated, killed, \&c., at the massacre ; it was done in a most correct way, but somehow made him most unaccountably and unreasonably angry. He joined the expedition that was sent in pursuit of the murderers, and in one of the first engagements some dozen of them were made prisoners. At night he approached them, and, taking treacherous advantage of their guileless confidence, asked them if they had participated in the massacre, feast, \&c.; and they, never dreaming that they had anything to fear from the admission, innocently answered in the affirmative, whereon this monster, knowing well that the poor fellows would escape capital, or even very serious, punishment, on the grounds that they were prisoners of war, or had brown skins, or excellent 
At moments like these I have had ideas on native policy that I dare not utter in the latitude of Exeter Hall, and the era of the nineteenth century.

But when New Zealand was colonized the feeling of the English public was distinctly philanthropical towards native races (especially at a distance), and the old policy was thoroughly discarded, for one, in its general theory and intention at least, more enlightened and more humane. Speaking broadly, I think one can see all through the chequered course of our Maori policy an earnest desire to treat the native as a man and a brother; to give him the status of a civilized man whenever it was possible to

motives, or a deficient moral sense, or a defective education, deliberately shot the whole lot with his revolver. I need hardly mention that had this act been performed by a Maori upon white men by way of "utu" (revenge, payment) for some of his tribe that had been killed, it would have been quite "tiku" (correct, proper); but for a white man so to behave was scandalous. I forget what punishment was awarded him: let us hope he got what he deserved; and may this story be a warning to those who let their angry passions rise.

The leader of the Hau Hau expedition was a ruffian called Te Kooti. The chief of the native contingent that joined in their pursuit was a Maori, of the old-fashioned sort, named Ropata. A friend of mine asked him one day what he thought would be done with Te Kooti if he were taken. "Oh, you'll make him a judge," answered Ropata, coolly. "What do you mean?" asked my friend. "Well," said Ropata, "the last two rebels you caught you made native assessors, and Te Kooti's a much greater man than either of them; so I don't see how you can do less than make him a judge. But you won't if $I$ catch him," he added, with a grin. 
do so; and when not possible to consider and make due allowance for the fact of his being uncivilized, and to guide and lead him torards civilization by just and generous treatment, and appeals to his moral and intellectual faculties.

I do not wish to dwell upon the dangerous extravagances into which such a policy might and did occasionally run-such as letting off one native cutthroat by treating him as a civilized prisoner of war, and repriering the next on the ground that he was a poor untutored sarage who knew no better, to the utter destruction and confusion of all sense of power, justice, and security-great as was the amount of mischief that they did, but will confine myself to what I believe was the main cause of the almost total failure of this noble and, in the main, plausible policy.

It is quite erident that to give it a chance of success it must have been founded on a thorough understanding of the native character. It is no use making signs to a man who cannot understand them, it is no use uttering the most lovely moral precepts in language that is sure to mislead him. It was in this first necessary step that I hold that we failed, with brilliant individual exceptions no doubt, who, however, only served to make the confusion worse with their gleams of light.

Narrow-minded Enthusiasm, Ignorance, and Carelessness all contributed their quota to the mischief, and their favourite blunder consisted in jumping at conclusions concerning native character from certain 
analogies with our own. It did not occur to many of us that actions which marked the presence of certain qualities in the English character, might mark the presence of very different ones in the Maori, and vice vers $\hat{a}$, or that qualities which marked the presence of certain other qualities in the Englishman might be very differently accompanied in the native; we did not realize the fact that the Maori reflected, argued, and acted in a way that was often as incomprehensible to us as our way was to him.

When we observed a band of native converts singing a hymn before advancing to battle we were filled with admiration at their piety, without perceiving that those deeper religious feelings which alone could have produced such a manifestation amongst Englishmen were entirely absent. ${ }^{1}$ When Christianity

1 The Maori notion of prayer reaches no higher than the thing we call an incantation. One day I was talking to the old Pakeha Maori (i.e. a white man who lives amongst the Maories) on the subject of missionary labour. At last he said, "I'll tell you a story that will establish your name for ever at Exeter Hall, only you musn't tell it quite the same way that I do. I was here at the time when both the Protestant and Roman Catholic missionaries were first beginning to make their way in the country; and the Maories of my tribe used to come to me and ask me which had the greatest 'mana' (i.e. fortune, prestige, power, strength) - the Protestant God or the Romanist one. I was always a good Churchman, and used to tell them that the Protestant God could lick the other into fits. There was an old Irish sailor about five miles from me who used to back up the Roman Catholic God, but I had a long start of him, and moreover was the best fighting man of the two, which went 
spread through the tribes with amazing rapidity, we rejoiced over their capability for accepting the doctrines of high and pure religion, never perceiving

a long way. In a short time I had about two hundred of the most muscular, blood-thirsty, hard-fighting Protestants you could wish to see.

"Well; it so happened that one day we had a little difference with some of our neighbours, and were drawn up on one side of a gully all ready to charge. I liked the fun of fighting in those days, and was rigged out in nothing but a cartridge-box and belt, with a plume of feathers in my hair, and a young woman to carry my ammunition for me; moreover, I had been put in command of the desperate joung bloods of the tribe, and burned to distinguish myself, feeling the commander of the Old Guard at Waterloo quite an insignificant person in regard to myself in point of responsibility and honour.

"Lying down in the fern, we waited impatiently for the signal to charge; had not we, on the last occasion worth speaking of, outrun our elders, and been nearly decimated in consequence? Shall it not be different now? See! there is the great war-chief, the commander of the 'Taua,' coming this way (he was a real ' toa' of the old stamp, too seldom found among the degenerate Maories of the present day). Little cared he for the new faith that had sprung up in the last generation; his skill with the spear, and the incantations of his 'Tohungas' (i.e. priests or magicians), had kept him safe through many a bitter tussle; his 'mana' was great. Straight to me he came and addressed me thus:- 'Look here, young fellow! I've done the incantations and made it all square with my God; but you say that you've got a God stronger than mine, and a lot of our young fellows go with you; there's nothing like having two Gods on our side, so you fellows do the proper business with him, and then we'll fight.' Could anything have been more practical and business-like than this? But I was quite stuck up; for though I could have repeated a prayer from the liturgy 
that they accepted it simply because they thought from our superiority in ships, arms, tools, and material prosperity in general, that the "Mana" (i.e., luck, power, prestige) of Christianity must be greater than that of their old superstition, and would be quite ready to leave it again when they found out this was a mistake, their minds being as void of the higher religious elements as those of many sarages far below them in intellectual porvers. When we heard of a native chief supplying his enemy with food or ammunition to enable him to carry on the war we were charmed with his generous chivalry, and immediately endowed him with all the virtues that usually accompany such behaviour in an Englishman, blind to the fact that the chief simply liked fighting as we might like eating or sleeping, and

myself, my worthy converts, who philosophically and rightly looked upon religion merely as a means to an end (i.e. killing the greatest possible quantity of enemies), were unable to produce a line of scripture amongst them.

"There was an awkward pause; our commander was furious. Suddenly one discovers that he has a hymn-book in his pocket. General exultation! 'Now!' cries the old chief, foaming at the mouth with excitement, 'go down upon your knees (I know that's the custom with your God) and repeat the charm after him. Mind you don't make a mistake, now, for if one word is wrong, the whole thing will be turned topsy-turvy, and we shall be thrashed.'

"And then, having repeated one hymn word for word on our knees, I and my converts charged, and walked into the Amorites no end; but whether it was the hymn or the fighting that did it is of course an open question to this day." 
furnished his enemy with arms and ammunition just as we might furnish one's cook with money to buy meat with. ${ }^{1}$

By radical misconceptions, such as these, we

1 Of the Maori's passion for fighting for its own sake, with the chivalrous appearance that it somerrhat misleadingly bore, I will give an instance. A certain chief had a missionary whom he desired to get rid of. Whether he mas tired of his sermons, disliked his ritual, or what, I cannot say. However, he forwarded him on to another chief, with his compliments, as a present. Chief number two not being in need of a chaplain, having no living racant, and having perhaps, too, a suspicion that the missionary was unsound in some respect from the careless way he was disposed of, declined him, and returned him untried. Chief number one was insulted, and declared that if chief number two had not known his superiority in arms and ammunition, he would not have dared to behare in such manner. When this came to the ears of number trro, he divided his arms, \&c., into two halves, and sent one to the enemy, with an inritation to war.

A distinguished friend of mine in Nerw Zealand once asked a Maori chief who had fought against us on the Waikato, why, when he had command of a certain road, he did not attack the ammunition and provision trains? "Why, you fool!" answered the Maori, much astonished, "If we had sto'en their powder and food, how could they have fought?"

Sometimes two villages would get up a little war, and the inhabitants, after potting at each other all day, would come out of their "pas" in the evening and talk orer their day's sport in the most friendly manner. "I nearly bagged your brother to-day." " Ah, but you should have seen how I made your old father-in-law skip!" and so on. After one or two had been really killed, they would become more in earnest.

I hare heard old Archdeacon —- of Tauranga, relate how in one of these petty wars he has known the defenders of a 
succeeded in creating in our imaginations an ideal Maori about as true to the life as a Fenimore Cooper Indian. And then we proceeded to impress the real Maori with moral lessons that he could not understand, and with practical examples that he interpreted all wrong, to appeal to qualities and ideas that he did not possess, and ignore those that he did possess, till in spite of our patience and goodwill we became puzzled by and disgusted with him, and he contemptuous of and utterly bewildered by us. I have heard several comments upon us and our policy from intelligent natives, none of them very flattering to our sagacity or consistency, but I will only give one which struck me as being a most striking comment upon a policy that aimed at conciliation, forbearance, and patient improvement of the Maori. "You are a good people, but you have no fixed plan and no understanding either in matters of peace or war. No man can tell when you will fight or when you will give presents to buy peace, or at what

pa send out to their adversaries to say they were short of provisions, who immediately sent them a supply to go on with. Also how he has performed service on Sunday between two belligerent pas, the inhabitants of which came out to pray, and met with the most perfect amity, returning to their pas when service was over, to recommence hostilities on Monday morning. The fact is, that they were, as the Pakeha Maori says, a race so demoralized by perpetual war that they had got to look instinctively upon fighting as the chief object in life. How difficult it was for the average Englishman to see this at first, and how misleading traits such as I have mentioned might be to him, it is not hard to imagine. 
sudden moment you will stop doing one and begin the other. No man can tell your reasons nor the meaning of what you do." This man had evidently caught some vague glimmerings of the meaning of our policy which only confused him the more. A little knowledge is a dangerous thing.

From the faithful pictures of Maori character, ideas, and feelings contained in these two little books, the observant reader will easily perceive how mistakes and misconceptions as to what they were, and might become, and as to how they should be treated, sprang up in the English mind. It is true that the Maori question, with all its hopes and fears, has practically come to an end. The bubble of Maori civilization has burst, the idea, that seemed at one time not unlikely to become an actual fact, of a native race becoming truly Christianized and civilized, and prospering side by side with their white brothers, has gone where many a noble and well-fought-for idea has gone before. The true level of the Maori, intellectually and morally, has become tolerably well known; moreover, his numbers are diminishing year by year.

But the English nation is, and I hope always will be, in contact with many nations of different blood and rarious forms and degrees of civilization, and as long as this is the case it cannot be too much impressed upon that extremely powerful and somewhat hasty and headstrong body, the British public, that human nature is not the same all over the world, that one man's meat is another man's poison, that 
there is no code either of logic or of feeling or of morals universally accepted by humanity, that every difference in custom makes some difference in mind; so that (if that public wishes, as I believe it does, to manage the races with whom England comes in contact, not so much by force as by intelligent and beneficial moral influence) the first thing to be done is to gain an unwarped, accurate, and thorough knowledge of the customs, character, and opinions of the races in question.

If these two little books should suggest to any careless Englishman that foreigners of dark complexion are not all like either those white men who seem to have got into brown or black skins by mistake, whom one reads about in anti-slavery books and some missionary reports, or those equally tiresome black dummies whom one reads about in another sort of book who have no marked characteristic or intelligible custom except shooting spears and arrows at people for no apparent reason, I shall be glad to have introduced them to an English public; and let me assure those who care more for amusement than instruction that they will be amply repaid by their perusal.

I hope the Pakeha Maori will pardon my impertinence in giving a personal sketch of him to his English readers on the plea that his writing would not be.complete without one.

He was, I believe, sixty years old when I first saw him, but, in spite of his age, looked the finest man for strength, activity, and grace I had ever seen. 
Six feet three in height and big in proportion, with a symmetry of shape that almost disguised his immense size, I felt I could well understand the stories I had heard of his popularity and his feats amongst the Maories, especially when I watched the keen, bright expression of his humorous Irish face.

In manner and conversation he was the very opposite of what one would expect of a man who had lived since his boyhood among savages. With a real love, and a considerable knowledge of literature, a keen appreciation of all intellectual excellence, and a most delightful humour, I think I never came across so charming a talker as the man whom I may not inaptly christen the "Lever" of New Zealand.

Penibroke. 



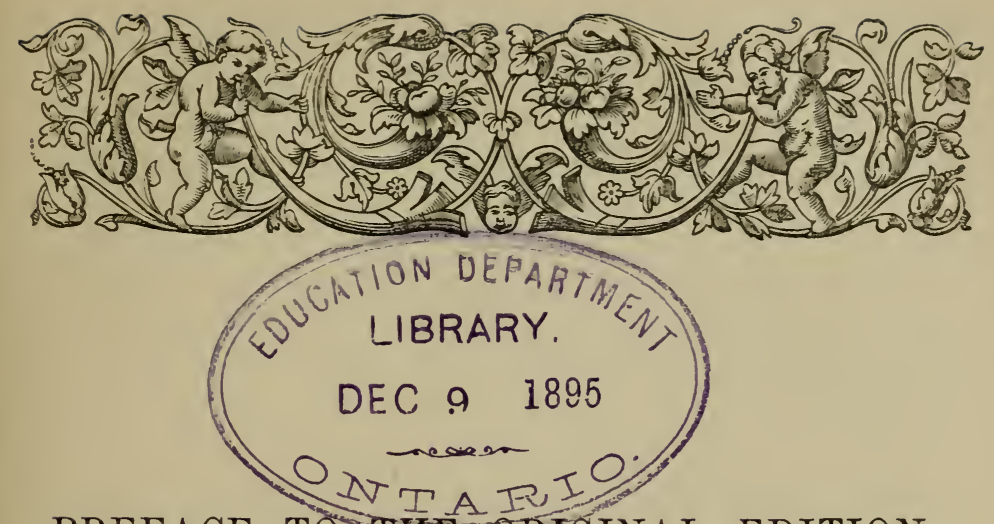

PREFACE TO THE ORIGINAL EDITION.

(3) 1. 1 those who have arrived in New ZeaSis last land within the last thirty

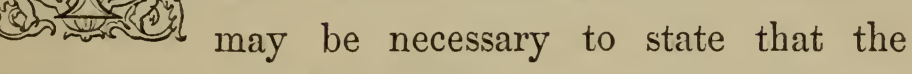
descriptions of Maori life and manners of past times found in these sketches owe nothing to fiction. The different scenes and incidents are given exactly as they occurred, and all the persons described are real persons.

Contact with the British settlers has of late years effected a marked and rapid change in the manners and mode of life of the natives, and the Maori of the present day are as unlike what they were when I first saw them as they are still unlike a civilised people or British subjects.

The writer has therefore thought it might be 
xxiv $P R E F A C E$.

worth while to place a fer sketches of old Maori life on record before the remembrance of them has quite passed away; though in doing so he has by no means exhausted an interesting subject, and a more full and particular delineation of old Maori life, manners, and history has yet to be written.

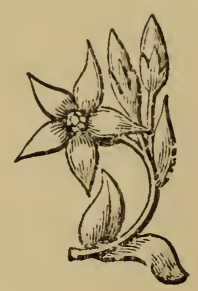




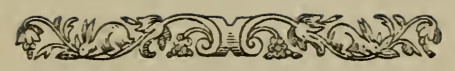

\section{OL D N E Z E A L N D ;}

A TALE OF THE GOOD

\section{OLD TIMES.}

\section{BY $\triangle$ PAKEHA MAORI.}

"Of Anthropophagi, and men whose heads

Do grow BETWEex their shoulders."

น⿻上丨冖 



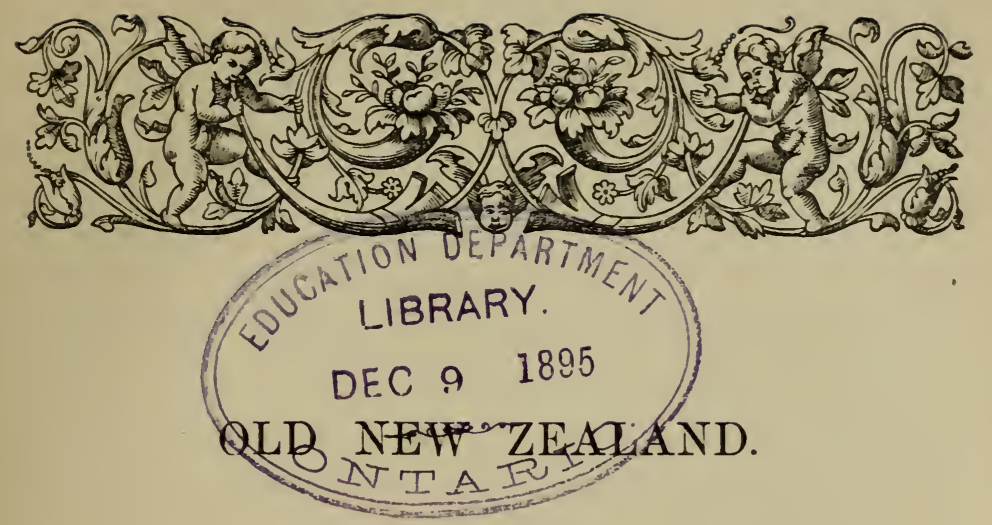

Chapter I.

Introductory.-First view of New Zealand. - First sight of the natives, and first sensations experienced by a mere Pakeha.A Maori chief's notions of trading in the old times.-A dissertation on "courage."-A few words on dress. - The chief's soliloquy.-The Maori cry of welcome.

came to New Zealand, we shall never
see their like again. Since then the how. A dull sort of world this now. The very sun does not seem to me to shine as bright as it used. Pigs and potatoes have degenerated; and everything seems "flat, stale, and unprofitable." But those were the times! - the "good old times"before Governors were invented, and law, and justice, and all that. When every one did as he liked,except when his neighbours would not let him, (the more shame for them,) - when there were no taxes, or duties, or public works, or public to require them. Who cared then whether he owned a coat?-or 
believed in shoes or stockings? The men were bigger and stouter in those days; and the women,ah! Money was useless and might go a begging. A sovereign was of no use except to make a hole in and hang it in a child's ear. The few I brought went that way, and I have seen them swapped for shillings, which were thought more becoming. What cared I? A fish-hook was worth a dozen of them, and I had lots of fish-hooks. Little did I think in those days that I should ever see here towns and villages, banks and insurance offices, prime ministers and bishops; and hear sermons preached, and see men hung, and all the other plagues of civilization. I am a melancholy man. I feel somehow as if I had got older. I am no use in these dull times. I mope about in solitary places, exclaiming often, "Oh ! where are those good old times?" and echo, or some young Maori whelp from the Three Kings, answers from behind a bush,-No HEA.

I shall not state the year in which I first saw the mountains of New Zealand appear above the sea; there is a false suspicion getting about that I am growing old. This must be looked down, so I will at present avoid dates. I always held a theory that time was of no account in New Zealand, and I do believe I was right up to the time of the arrival of the first Governor. The natives hold this opinion still, especially those who are in debt: so I will just say it was in the good old times, long ago, that, from the deck of a small trading schooner in which I had taken my passage from somewhere, I first cast eyes 
on Maori land. It was Maori land then; but alas! what is it now? Success to you, O King of Waikato. May your mana never be less!-long may you hold at bay the demon of civilization, though fall at last I fear you must. Plutus with golden hoof is trampling on your landmarks. He mocks the war-song; but should $I$ see your fall, at least one Pakeha Maori shall raise the tangi; and with flint and shell as of old shall the women lament you.

Let me, however, leave these melancholy thoughts for a time, forget the present, take courage, and talk about the past. I have not got on shore yet; a thing I must accomplish as a necessary preliminary to looking about me, and telling what I saw. I do not understand the pakeha way of beginning a story in the middle; so to start fair, I must fairly get on shore, which, I am surprised to find, was easier to do than to describe.

The little schooner neared the land, and as we came closer and closer, I began in a most unaccountable manner to remember all the tales I had ever heard of people being baked in ovens, with cabbage and potato "fixins." I had before this had some considerable experience of "savages," but as they had no regular system of domestic cookery of the nature I have hinted at, and being, as I was in those days, a mere pakeha (a character I hare since learned to despise), I felt, to say the least, rather curious as to the then existing demand on shore for butchers' meat.

The ship sailed on, and I went below and loaded 
my pistols; not that I expected at all to conquer the country with them, but somehow because I could not help it. We soon came to anchor in a fine harbour before the house of the very first settler who had ever entered it, and to this time he was the only one. He had, however, a few Europeans in his employ; and there was at some forty miles distance a sort of nest of English, Irish, Scotch, Dutch, French, and American runaways from South Sea whalers, with whom were also congregated certain other individuals of the pakeha race, whose manner of arrival in the country was not clearly accounted for, and to enquire into which was, as I found afterwards, considered extremely impolite, and a great breach of bienséance. They lived in a half savage state, or to speak correctly, in a savage and-a-half state, being greater savages by far than the natives themselves.

I must, however, turn back a little, for I perceive I am not on shore yet.

The anchoring of a vessel of any size, large or small, in a port of New Zealand, in those days, was an event of no small importance; and, accordingly, from the deck we could see the shore crowded by several hundreds of natives, all in a great state of excitement, shouting and running about, many with spears and clubs in their hands, and altogether looking to the inexperienced new-comer very much as if they were speculating on an immediate change of diet. I must say these at least were my impressions on seeing the mass of shouting, gesticulating, tattooed fellows, who were exhibiting before us, and 
who all seemed to be mad with excitement of soine sort or other. Shortly after we came to anchor, a boat came off, in which was Mr. - - the settler I have mentioned, and also the principal chief of the tribe of natives inhabiting this part of the country. $\mathrm{Mr}$. - - gave me a hearty welcome to New Zealand, and also an invitation to his house, telling me I was welcome to make it my home for any unlimited time, till I had one of my own. The chief also-having made some enquiries first of the captain of the schooner, such as whether I was a rangatira, if I had plenty of taonga (goods) on board, and other particulars; and having been answered by the captain in the most satisfactory manner,-came up to me and gave me a most sincere welcome. (I love sincerity.) He would have welcomed me, however, had I been as poor as Job, for pakehas were, in those days, at an enormous premium. Even Job, at the worst (a pakeha Job), might be supposed to have an old coat, or a spike nail, or a couple of iron hoops left on hand, and these were "good trade" in the times I speak of; and under a process well understood at the time by my friend the chief, were sure to change hands soon after his becoming aware of their whereabouts. His idea of trade was this:He took them, and never paid for them till he took something else of greater value, which, whatever it might be, he never paid for till he made a third still heavier haul. He always paid just what he thought fit to give, and when he chose to withdraw his patronage from any pakeha who might be getting 
too knowing for him, and extend it to some newer arrival, he never paid for the last "lot of trade;" but, to give him his due, he allowed his pakeha friends to make the best bargain they could with the rest of the tribe, with the exception of a few of his nearest relations, over whose interests he would watch. So, after all, the pakeha would make a living; but I have never heard of one of the old traders who got rich by trading with the natives: there were too many drawbacks of the nature I have mentioned, as well as others unnecessary to mention just yet, which prevented it.

I positively vow and protest to you, gentle and patient reader, that if ever I get safe on shore, I will do my best to give you satisfaction; let me get once on shore, and I am all right: but unless I get my feet on terrâ firmâ, how can I ever begin my tale of the good old times? As long as I am on board ship I am cramped and crippled, and a mere slave to Greenwich time, and can't get on. Some people, I am aware, would make a dash at it, and manage the thing without the aid of boat, canoe, or life preserver; but such people are, for the most part, dealers in fiction, which I am not: my story is a true story, not "founded on fact," but fact itself, and so I cannot manage to get on shore a moment sooner than circumstances will permit. It may be that I ought to have landed before this; but I must confess I don't know any more about the right way to tell a story, than a native minister knows how to "come" a war dance. I declare the mention of the war 
dance calls up a host of reminiscences, pleasurable and painful, exhilarating and depressing, in such a way as no one but a few, a very few, pakeha Maori, can understand. Thunder!-but no; let me get ashore; how can I dance on the water, or before I erer knew how? On shore I will get this time, I am determined, in spite of fate-so now for it.

The boat of my friend $\mathrm{Mr}$. _ - being about to return to the shore, leaving the chief and Mr. - - on board, and I seeing the thing had to be done, plucked up cournge, and haring secretly felt the priming of my pistols under my coat, got into the boat.

I must here correct myself. I have said, "plucked up courage," but that is not exactly my meaning. The fact is, kind reader, if you have followed me thus far, you are about to be rewarded for your perseverance. I am determined to make you as wise as I am myself on at least one important subject, and that is not saying a little, let me inform you, as I can hardly suppose you have made the discovery for yourself on so short an acquaintance. Falstaff, who was a very clever fellow, and whose word cannot be doubted, says-" The better part of valour is discretion." Now, that being the case, what in the name of Achilles, Hector, and Colonel Gold (he, I mean Achilles, was a rank coward, who went about knocking people on the head, being himself next thing to invulnerable, and who could not be hurt till he turned his back to the enemy. There is a deep moral in this same story about Achilles which per- 
haps, by and bye, I may explain to you)-what, I say again, in the name of everything valorous, can the worser part of valour be, if " discretion" be the better? The fact is, my dear sir, I don't believe in courage at all, nor ever did; but there is something far better, which has carried me through many serious scrapes with éclât and safety; I mean the appearance of courage. If you have this you may drive the world before you. As for real courage, I do not believe there can be any such thing. A man who sees himself in danger of being killed by his enemy and is not in a precious fright, is simply not courageous but mad. The man who is not frightened because he cannot see the danger, is a person of weak mind-a fool-who ought to be locked up lest he walk into a well with eyes open; but the appearance of courage, or rather, as I deny the existence of the thing itself, that appearance which is thought to be courage, that is the thing will carry you through! - get you made K.C.B., Victoria Cross, and all that! Men by help of this quality do the most heroic actions, being all the time ready to die of mere fright, but keeping up a good countenance all the time. Here is the secret-pay attention, it is worth much money-if ever you get into any desperate battle or skirmish, and feel in such a state of mortal fear that you almost wish to be shot to get rid of it, just say to yourself- "If I am so preciously frightened, what must the other fellow be?" The thought will refresh you; your own self-esteem will answer that of course the enemy is more frightened 
than you are, consequently, the nearer you feel to running away the more reason you have to stand. Look at the last gazette of the last victory, where thousands of men at one shilling per diem, minus certain very serious deductions, "covered themselves with glory." The thing is clear: the other fellows ran first, and that is all about it! My secret is a very good secret; but one must of course do the thing properly; no matter of what kind the danger is, you must look it boldly in the face and keep your wits about you, and the more frightened you get the more determined you must be-to keep up appearances-and half the danger is gone at once. So now, having corrected myself, as well as given some valuable advice, I shall start again for the shore by saying that I plucked up a very good appearance of courage and got on board the boat.

For the honour and glory of the British nation, of which I considered myself in some degree a representative on this momentous occasion, I had dressed myself in one of my best suits. My frock coat was, I fancy, "the thing;" my waistcoat was the result of much and deep thought, in cut, colour, and material -I may venture to affirm that the like had not been often seen in the southern hemisphere. My tailor has, as I hear, long since realized a fortune and retired, in consequence of the enlightenment he at different times receired from me on the great principles of, not clothing, but embellishing the human subject. My hat looked down criticism, and my whole turnout such as I calculated would "astonish the na- 
tives," and cause awe and respect for myself individually and the British nation in general, of whom I thought fit to consider myself no bad sample. Here I will take occasion to remark that some attention to ornament and elegance in the matter of dress is not only allowable but commendable. Man is the only beast to whom a discretionary power has been left in this respect: why then should he not take a hint from nature, and endeavour to beautify his person? Peacocks and birds of paradise could no doubt live and get fat though all their feathers were the colour of a Quaker's leggings, but see how they are ornamented! Nature has, one would say, exhausted herself in beautifying them. Look at the tiger and leopard! Could not they murder without their stripes and spots?-but see how their coats are painted! Look at the flowers - at the whole universe -and you will see everywhere the ornamental combined with the useful. Look, then, to the cut and colour of your coat, and do not laugh at the Maori of past times, who, not being "seized" of a coat because he has never been able to seize one, carves and tattoos legs, arms, and face.

The boat is, however, darting towards the shore, rapidly propelled by four stout natives. My friend - and the chief are on board. The chief has got his eye on my double gun, which is hanging up in the cabin. He takes it down and examines it closely. $\mathrm{He}$ is a good judge of a gun. It is the best tupara he has ever seen, and his speculations run something very like this:-_" A good gun, a first-rate gun; I 
must have this; I must tapu it before I leave the ship [here he pulls a piece of the fringe from his cloak and ties it round the stock of the gun, thereby rendering it impossible for me to sell, give away, or dispose of it in any way to anyone but himself]; I wonder what the pakeha will want for it! I will promise him as much flax or as many pigs as ever he likes for it. True, I have no flax just now, and am short of pigs, they were almost all killed at the last hahunga; but if he is in a hurry he can buy the flax or pigs from the people, which ought to satisfy him. Perhaps he would take a piece of land! - that would be famous. I would give him a piece quite close to the kainga, where I would always have him close to me; I hope he may take the land; then I should hare two pakehas, him and - - All the inland chiefs would enry me. This — is getting too knowing; he has taken to hiding his best goods of late, and selling them before I knew he had them. It's just the same as thieving, and I won't stand it. He sold three muskets the other day to the Ngatiwaki, and I did not know he had them, or I should have taken them. I could have paid for them some time or another. It was wrong, wrong, very wrong, to let that tribe have those muskets. He is not their pakeha; let them look for a pakeha for themselves. Those Ngatiwaki are getting too many muskets-those three make sixty-four they have got besides two tupara. Certainly we have a great many more, and the Ngatiwaki are our relations, but then there was Kohu, we killed, and Patu, we stole his wife. There is no say- 
ing what these Ngatiwaki may do if they should get plenty of muskets; they are game enough for anything. It was wrong to give them those muskets; wrong, wrong, wrong!" After-experience enabled me to tell just what the chief's soliloquy was, as above.

But all this time the boat is darting to the shore, and as the distance is only a couple of hundred yards, I can hardly understand how it is that I have not yet landed. The crew are pulling like mad, being impatient to show the tribe the prize they have made, - a regular pakeha rangatira as well as a rangatira pakeha (two very different things), who has lots of tomahawks, and fish-hooks, and blankets, and a tupara, and is even suspected to be the owner of a great many "pots" of gunpowder! "He is going to stop with the tribe, he is going to trade, he is going to be a pakeha for us." These last conclusions were, however, jumped at, the "pakeha" not having then any notions of trade or commerce, and being only inclined to look about and amuse himself. The boat nears the shore, and now arises from a hundred voices the call of welcome,-_"Haere mai! haere mai! hoe mai! hoe mai! haere mai, e-te-pa-ke-ha, haere mai! mats, hands, and certain ragged petticoats put into requisition for that occasion, all at the same time waving in the air in sign of welcome. Then a pause. Then, as the boat came nearer, another burst of haere mai! But unaccustomed as I was then to the Maori salute, I disliked the sound. There was a wailing melancholy cadence that did not strike me as being the appropriate 
tone of welcome; and, as I was quite ignorant up to this time of my own importance, wealth, and general value as a pakeha, I began, as the boat closed in with the shore, to ask myself whether possibly this same "haere mai" might not be the Maori for "dilly, dilly, come and be killed." There was, however, no help for it now; we were close to the shore, and so, putting on the most unconcerned countenance possible, I prepared to make my entrée into Maori land in a proper and dignified manner.

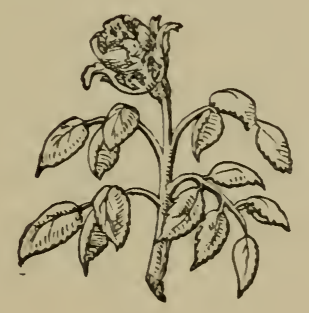




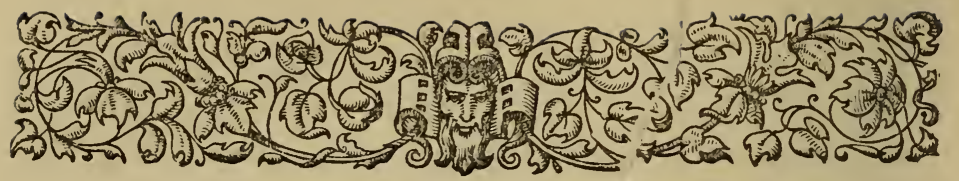

Cinapter II.

The market price of a Pakeha.-The iv value of a Pakeha "as such."-Maori hospitality in the good oll il times.-A respectable friend.-Maori mermaids.-My notions " ${ }^{1}$ of the value of gold.How I got on shore.

(n) days the value of a pal liaeha to a tribe was enormous. For w want of pakehas to trade with, and frol isn whom to procure tribes were about this time ext, nerminated or nearly so by their more fortunate ni reighbours who got pakehas before them, and who iconsequently became armed with muskets first. A ise pakeha trader was therefore of a value say about i twenty times his own weight in muskets. This, a laccording to my notes made at the time, I find to $h$ - $x$-lave represented a value in New Zealand something a setrbout what we mean in England when we talk of $t t^{\top}$ the sum total of the national debt. A book-keene. per, or a second-rate pakeha, not a trader, migr, notiu be valued at say his weight in tomahawks; an Nasenormous sum also. The poorest labouring pakeha, ierethough he might have no property, would earn som.e mething-his value to the 
chief and tribe with whom he lived might be estimated at say his weight in fish-hooks, or about a hundred thousand pounds or so; value estimated by eagerness to obtain the article.

The value of a musket was not to be estimated to a native by just what he gave for it; he gave all he had, or could procure, and had he ten times as much to give he would have given it, if necessary, or if not, he would buy ten muskets instead of one. Muskets! muskets! muskets! nothing but muskets, was the first demand of the Maori; muskets and gunpowder at any cost.

I do not, however, mean to affirm that pakehas were at this time ralued "as such,"-like Mr. Pickwick's silk stockings, which were very good and valuable stockings, "as stockings" - not at all. A loose, straggling pakeha-a runaway from a ship for instance,- who had nothing, and was never likely to have anything, a vagrant straggler passing from place to place,- -was not of much account even in those times. Two men of this description (runaway sailors) were hospitably entertained one night by a chief, a very particular friend of mine, who, to pay himself for his trouble and outlay, eat one of them next morning. Remember, my good reader, I don't deal in fiction; my friend eat the pakeha sure enough, and killed him before he eat him, which was civil, for it was not always done. But then, certainly, the pakeha was a tutua, a nobody, a fellow not worth a spike nail; no one knew him; he had no relations, no goods, no expectations, no anything: 
beaver hat! Carry! He would lie down and make a bridge of his body, with pleasure, for him. Has he not half a shipful of taonga?

Well, having stepped in as dignified a manner as I knew how, from thwart to thwart, till I came to the bow of the boat, and having tightened on my hat and buttoned up my coat, I fairly mounted on the broad shoulders of my aboriginal friend. I felt at the time that the thing was a sort of failure-a come down; the position was not graceful, or in any way likely to suggest ideas of respect or awe, with my legs projecting a yard or so from under each arm of my bearer, holding on to his shoulders in the most painful, cramped, and awkward manner. To be sacked on shore thus, and delivered like a bag of goods thus, into the hands of the assembled multitude, did not strike me as a good first appearance on this stage. But little, indeed, can we tell in this world what one second may produce. Gentle reader, fair reader, patient reader! The fates have decreed it; the fiat has gone forth ; on that man's back I shall never land in New Zealand. Manifold are the doubts and fears which have yet to shake and agitate the hearts and minds of all my friends as to whether I shall ever land at all, or ever again feel terrâ firmâ touch my longing foot. My bearer made one step; the rock is slippery; backwards he goes; back, back! The steep is near-is passed! down, down, we go! backwards and headlong to the depths below!

The ebb tide is running like a sluice; in an instant we are forty yards off, and a fathom below the sur- 
face; ten more fathoms are beneath us. The heels of my boots, my polished boots, point to the upper air-ay, point; but when, oh, when again, shall I salute thee, gentle air; when again, unchoked by the saline flood, cry Veni aura? When, indeed! for now I am wrong end uppermost, drifting away with the tide, and ballasted with heavy pistols, boots, tight clothes, and all the straps and strings of civilization. Oh, heavens! and oh earth! and oh ye little thieves of fishes who manage to live in the waters under the earth (a miserable sort of life you must have of it!) oh Maori sea nymphs! who, with yellow hairyellow? egad-that's odd enough, to say the least of it; however the Maori should come to give their sea nymphs or spirits yellow hair is curious. The Naori know nothing about yellow hair; their hair is black. About one in a hundred of them have a sort of dirty-brown hair; but even if there should be now and then a native with yellow hair, how is it that they have come to give this colour to the sea-sprites in particular?- who also "dance on the sands, and yet no footstep seen." Now I confess I am rather puzzled and struck by the coincidence. I don't believe Shakespeare ever was in New Zealand; Jason might, being a seafaring-man, and if he should have called in for wood and water, and happened to have the golden fleece by any accident on board, and by any chance put it on for a wig, why the thing would be accounted for at once. The world is mad now-adays about gold, so no one cares a fig about what is called "golden hair;" nuggets and dust have the 
beaver hat! Carry! He would lie down and make a bridge of his body, with pleasure, for him. Has he not half a shipful of taonga?

Well, having stepped in as dignified a manner as I knew how, from thwart to thwart, till I came to the bow of the boat, and having tightened on my hat and buttoned up my coat, I fairly mounted on the broad shoulders of my aboriginal friend. I felt at the time that the thing was a sort of failure-a come down; the position was not graceful, or in any way likely to suggest ideas of respect or awe, with my legs projecting a yard or so from under each arm of my bearer, holding on to his shoulders in the most painful, cramped, and awkward manner. To be sacked on shore thus, and delivered like a bag of goods thus, into the hands of the assembled multitude, did not strike me as a good first appearance on this stage. But little, indeed, can we tell in this world what one second may produce. Gentle reader, fair reader, patient reader! The fates have decreed it; the fiat has gone forth; on that man's back I shall never land in New Zealand. Manifold are the doubts and fears which have yet to shake and agitate the hearts and minds of all my friends as to whether I shall ever land at all, or ever again feel terrâ firmâ touch my longing foot. My bearer made one step; the rock is slippery; backwards he goes; back, back! The steep is near-is passed! down, down, we go! backwards and headlong to the depths below!

The ebb tide is running like a sluice; in an instant we are forty yards off, and a fathom below the sur- 
face; ten more fathoms are beneath us. The heels of my boots, my polished boots, point to the upper air-ay, point; but when, oh, when again, shall I salute thee, gentle air; when again, unchoked by the saline flood, cry Veni aura? When, indeed! for now I am wrong end uppermost, drifting away with the tide, and ballasted with heavy pistols, boots, tight clothes, and all the straps and strings of civilization. Oh, heavens! and oh earth! and oh ye little thieves of fishes who manage to live in the waters under the earth (a miserable sort of life you must have of it!) oh Maori sea nymphs! who, with yellow hairyellow? egad—that's odd enough, to say the least of it; however the Maori should come to give their sea nymphs or spirits yellow hair is curious. The Maori know nothing about yellow hair; their hair is black. About one in a hundred of them have a sort of dirty-brown hair; but even if there should be now and then a native with yellow hair, how is it that they have come to give this colour to the sea-sprites in particular?-who also "dance on the sands, and yet no footstep seen." Now I confess I am rather puzzled and struck by the coincidence. I don't believe Shakespeare ever was in New Zealand; Jason might, being a seafaring-man, and if he should have called in for wood and water, and happened to have the golden fleece by any accident on board, and by any chance put it on for a wig, why the thing would be accounted for at once. The world is mad now-adays about gold, so no one cares a fig about what is called "golden hair;" nuggets and dust have the 
preference; but this is a grand mistake. Gold is no use, or very little, except in so far as this-that through the foolishness of human beings, one can purchase the necessaries and conveniences of life with it. Now, this being the case, if I have a chest full of gold (which I have not), I am no richer for it in fact until $I$ have given it away in exchange for necessaries, comforts, and luxuries, which are, properly speaking, riches or wealth; but it follows from this, that he who has given me this same riches or wealth for my gold, has become poor, and his only chance to set himself up again is to get rid of the gold as fast as he can, in exchange for the same sort and quantity of things, if he can get them, which is always doubtful. But here lies the gist of the matter-how did I, in the first instance, become possessed of my gold? If I bought it, and gave real wealth for it, beef, mutton, silk, tea, sugar, tobacco, ostrich feathers, leather breeches, and crinoline,why, then, all I have done in parting with my gold, is merely to get them back again, and I am, consequently, no richer by the transaction; but if I steal my gold, then I am a clear gainer of the whole lot of valuables above mentioned. So, upon the whole, I don't see much use in getting gold honestly, and one must not steal it: digging it certainly is almost as good as stealing, if it is not too deep, which fully accounts for so many employing themselves in this way; but then the same amount of labour would raise no end of wheat and potatoes, beef and mutton: and all farmers, mathematicians, and algebraists will agree 
with me in this-that after any country is fully cultivated, all the gold in the world won't force it to grow one extrackatrip, andwhat more can any

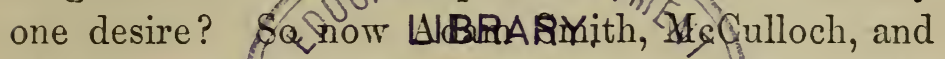
all the rest of themDengy oro and hayged. The whole upshot of this treatise on politigal economy and golden hair, the Colonial Treasurer, is this :- I would not give one of your golden locks, my dear, for all the gold, silver, pearls, diamonds, mere ponamus-stop, let me think, - a good mere ponamu would be a temptation. I had once a mere, a present from a Maori friend, the most beautiful thing of the kind ever seen. It was nearly as transparent as glass; in it there were beautiful marks like fern leaves, trees, fishes, and-I would not give much for a person who could not see almost anything in it. Never shall I cease to regret having parted with it. The Emperor of Brazil, I think, has it now; but he does not know the proper use of it. It wont to the Minister many years ago. I did not sell it. I would have scorned to do that; but I did expect to be made knight of the golden pig knife, or elephant and watch box, or something of that nature: but here I am still, a mere pakeha Maori, and, as I recollect, in desperate danger of being drowned.

Up we came at last, blowing and puffing like grampuses. With a glance I "recognised the situation:"-we had drifted a long way from the landing place. My hat was dashing away before the land breeze towards the sea and had already made a good 
"offing." Three of the boat's-crew had jumped overboard, had passed us a long distance, and were seemingly bound after the hat; the fourth man was pulling madly with one oar, and consequently making great progress in no very particular direction. The whole tribe of natives had followed our drift along the shore, shouting and gesticulating, and some were launching a large canoe, evidently bent on saring the hat, on which all eyes were turned. As for the pakeha, it appears they must have thought it an insult to his understanding to suppose he could be drowned anywhere in sight of land. "'Did he not come from the sea?' Was he not a fish? Was not the sea solid land to him? Did not his fire burn on the ocean? Had he not slept on the crests of the waves?" All this I heard afterwards; but at the time had I not been as much at home in the water as anything not amphibious couid be, I should have been very little better than a gone pakeha. Here was a pretty wind up! I was going to "astonish the natives," was I?-with my black hat and my koti roa? But the villain is within a yard of me-the rascally cause of all my grief. The furies take possession of me! I dart upon him like a hungry shark! I have him! I have him under! Down, villain! down to the kraken and the whale, to the Taniwha cave!-down! down! down! As we sank I heard one grand roar of wild laughter from the shore-the word utu I heard roared by many voices, but did not then know its import. The pakeha was drowning the Maori for 
utu for himself, in case he should be drowned. No matter, if the Maori can't hold his own, it's fair play; and then, if the pakeha really does drown the Maori, has he not lots of taonga to be robbed of?-no, not exactly to be robbed of, either; let us not use unnecessarily bad language-we will say to be distrained upon. Crack! What do I hear? Down in the deep I felt a shock, and actually heard a sudden noise. Is it the "crack of doom?" No, it is my frock-coat gone at one split "from clue to earing"split down the back. Oh if my pistols would go off, a fiery and watery death shouldst thou die, Caliban. Egad! they have gone off-they are both gone to the bottom! My boots are getting heavy! Humane Society, ahoy! where is your boat-hook?-where is your bellows? Humane Society, ahoy! We are now drifting fast by a sandy point, after which there will be no chance of landing - the tide will take us right out to sea. My friend is very hard to drown-must finish him some other time. We both swim for the point, and land; and this is how I got ashore on Maori land.

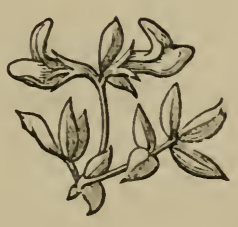




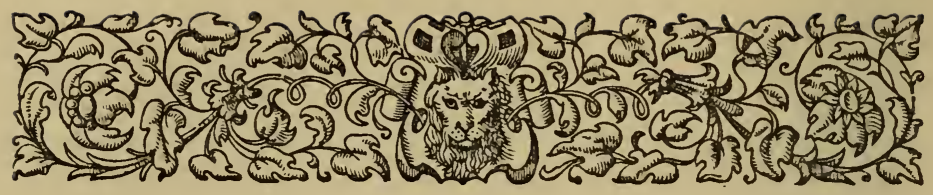

\section{Chapter III.}

A wrestling match.-Beef against melons.-The victor gains a loss.-"Our chief."-His speech.-His status in the tribe.Death of "Melons." - Rumours of peace and war. - Getting the $\mathrm{Pa}$ in fighting order.- My friend the "relation eater." - Expectation and preparation.-Arrival of doubtful friends.- Sham fight. -The "taki." - The war dance.-Another example of Maori hospitality.-Crocodile's tears.-Loose notions about heads.Tears of blood.-Brotherly love.-Capital felony.-Peace.

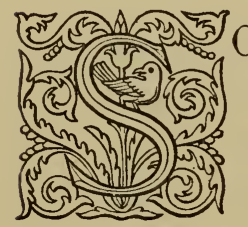

OMETHING between a cheer, a scream, and a roar, greet our arrival on the sand. An English voice salutes me out." One half of my coat hangs from my right elbow, the other from my left; a small shred of the collar is still around my neck. My hat, alas! my hat is gone. I am surrounded by a dense mob of natives, laughing, shouting, and gesticulating in the most grotesque manner. Three Englishmen are also in the crowd-they seem greatly amused at something, and offer repeated welcomes. At this moment up comes my salt-water acquaintance, elbowing his way through the crowd; there is a strange serio-comic expression of anger in his face; he stoops, makes horrid grimaces, quivering at the same time his 
left hand and arm about in a most extraordinary manner, and striking the thick part of his left arm with the palm of his right hand. "Hu!" says he, "hu! hu!" "What can he mean?" said I. "He is challenging you to wrestle," cried one of the Englishmen; "he wants utu." "What is utu?" said I. "Payment." "I won't pay him." "Oh, that's not it, he wants to take it out of you wrestling." "Oh, I see; here's at him; pull off my coat and boots; I'll wrestle him; his foot is in his own country, and his name is-what?" "Sir, his name in English means 'An eater of melons;' he is a good wrestler; you must mind." "Water-melons, I suppose; beef against melons for ever, hurrah! here's at him." Here the natives began to run between us to separate us, but seeing that I was in the humour to "have it out," and that neither self or friend were actually out of temper, and no doubt expecting to see the pakeha floored, they stood to one side and made a ring. A wrestler soon recognises another, and my friend soon gave me some hints that showed me I had some work before me. I was a youngster in those days, all bone and sinew, full of animal spirits, and as tough as leather. A couple of desperate main strength efforts soon convinced us both that science or endurance must decide the contest. My antagonist was a strapping fellow of about five-and-twenty, tremendously strong, and much heavier than me. I, however, in those days actually could not be fatigued; I did not know the sensation, and could run from morning till night. I therefore trusted to 
wearing him out, and avoiding his ta and wiri. All this time the mob were shouting encouragement to one or other of us. Such a row never was seen. I soon perceived I had a "party." "Well done, pakeha!" "Now for it, Melons!" "At him again!" "Take care, the pakeha is a taniwha; the pakeha is a tino tangata!" "Hooray!" (from the British element). "The Pakeha is down!" "No he isn't!" (from English side). Here I saw my friend's knees beginning to tremble. I made a great effort, administered my favourite remedy, and there lay the "Eater of melons" prone upon the sand. I stood a victor; and like many other conquerors, a very great loser. There I stood, minus hat, coat, and pistols, wet and mauled, and transformed very considerably for the worse since I left the ship. When my antagonist fell, the natives gave a great shout of triumph, and congratulated me in their own way with the greatest goodwill. I could see I had got their good opinion, though I scarcely could understand how. After sitting on the sand some time my friend arose, and with a very graceful movement, and a smile of good nature on his dusky countenance, he held out his hand and said in English, "How do you do?"

I was much pleased at this; the natives had given me fair play, and my antagonist, though defeated both by sea and land, offered me his hand, and welcomed me to the shore with his whole stock of English-" How do you do?"

But the row is not half over yet. Here comes the 
chief in the ship's boat. The other is miles off with its one man crew still pulling no one knows, or at all cares, where. Some one has been off in a canoe and told the chief that "Melons" and the "New Pakeha" were fighting like mad on the beach. Here he comes, flourishing his mere ponamu. He is a tall, stout fellow, in the prime of life, black with tattooing, and splendidly dressed, according to the splendour of those days. He has on a very good blue jacket, no shirt or waistcoat, a pair of duck trousers, and a red sash round his waist; no hat or shoes, these being as yet things beyond a chief's ambition. The jacket was the only one in the tribe; and amongst the surrounding company I saw only one other pair of trousers, and it had a large hole at each knee, but this was not considered to detract at all from its value. The chief jumps ashore; he begins his oration, or rather to "blow up" all and sundry the tribe in general, and poor "Melons" in particular. He is really vexed, and wishes to appear to me more vexed than he really is. He runs, gesticulating and flourishing his mere, about ten steps in one direction, in the course of which ten steps he delivers a sentence; he then turns and runs back the same distance, giving rent to his wrath in another sentence, and so back and forward, forward and back, till he has exhausted the subject and tired his legs. The Englishmen were beside me and gare a running translation of what he said. "Pretty work this," he began, "good work; killing my pakeha; look at him! (Here a flourish in my direction with the mere.) I won't 
stand this; not at all! not at all! not at all! (The last sentence took three jumps, a step, and a turnround, to keep correct time.) Who killed the pakeha? It was Melons. You are a nice man, are you not? (This with a sneer.) Killing my pakeha! (In a voice like thunder, and rushing savagely, mere in hand, at poor Melons, but turning exactly at the end of the ten steps and coming back again.) It will be heard of all over the country; we shall be called the 'pakeha killers;' I shall be sick with shame; the pakeha will run away, and take all his taonga along with him. What if you had killed him dead, or broken his bones? his relations would be coming across the sea for utu. (Great sensation, and I try to look as though I would say ' of course they would.') What did I build this pa close to the sea for?-was it not to trade with the pakehas?-and here you are killing the second that has come to stop with me. (Here poor Melons burst out crying like an infant.) Where is the hat?- where the koti roa? - where the shoes?-(Boots were shoes in those days.) The pakeha is robbed; he is murdered! (Here a howl from Melons, and I go over and sit down by him, clap him on the bare back, and shake his hand.) Look at that-the pakeha does not bear malice; I would kill you if he asked me; you are a bad people, killers of pakehas; be off with you, the whole of you, away!" This command was instantly obeyed by all the women, boys, and slaves. Melons also, being in disgrace, disappeared; but I observed that "the whole of you" did not seem to be understood 
as including the stout, able-bodied, tattooed part of the population, the strength of the tribe-the warriors, in fact, many of whom counted themselves to be very much about as good as the chief. They were his nearest relations, without whose support he could do nothing, and were entirely beyond his control.

I found afterwards that it was only during actual war that this chief was perfectly absolute, which arose from the confidence the tribe had in him, both as a general and a fighting man, and the obvious necessity that in war implicit obedience be given to one head. I have, however, observed in other tribes, that in war they would elect a chief for the occasion, a war chief, and have been surprised to see the obedience they gave him, even when his conduct was very open to criticism. I say with surprise, for the natives are so self-possessed, opinionated, and republican, that the chiefs have at ordinary times but little control over them, except in very rare cases, where the chief happens to possess a singular vigour of character, or some other unusual advantage, to enable him to keep them under.

I will mention here that my first antagonist, "The Eater of Melons," became a great friend of mine. He was my right-hand man and manager when I set up house on my own account, and did me many friendly services in the course of my acquaintance with him. He came to an unfortunate end some years later. The tribe were getting ready for a war expedition; poor Melons was filling cartridges from a fifty-pound barrel of gunpowder, pouring the gun- 
powder into the cartridges with his hand, and smoking his pipe at the time, as I have seen the natives doing fifty times since. A spark fell into the cask, and it is scarcely necessary to say that my poor friend was roasted alive in a second. I have known three other accidents of the same kind, from smoking whilst filling cartridges. In one of these accidents three lives were lost, and many injured; and I really do believe that the certainty of death will not prevent some of the natives from smoking for more than a given time. I have often seen infants refuse the mother's breast, and cry for the pipe till it was given them; and dying natives often ask for a pipe, and die smoking. I can clearly perceive that the young men of the present day are neither so tall, or stout, or strong as men of the same age were when I first came to the country; and I believe that this smoking from their infancy is one of the chief causes of this decrease in strength and stature.

I am landed at last, certainly; but I am tattered and wet, and in a most deplorable plight: so to make my story short, for I see, if I am too particular, I shall never come to the end of it, I returned to the ship, put myself to rights, and came on shore next day with all my taonga, to the great delight of the chief and tribe. My hospitable entertainer, Mr. - found room for my possessions in his store, and a room for myself in his house; and so now I am fairly housed we shall see what will come of it.

I have now all New Zealand before me to caper about in; so I shall do as I like, and please myself. 
I shall keep to neither rule, rhyme, or reason, but just write what comes uppermost to my recollection of the good old days. Nany matters which seemed odd enough to me at first, have long appeared such mere matters of course, that I am likely to pass them over without notice. I shall, however, give some of the more striking features of those delectable days, now, alas! passed and gone. Some short time after this, news came that a grand war expedition, which had been absent nearly two years at the South, had returned. This party were about a thousand strong, being composed of two parties of about five hundred men each, from two different tribes, who had joined their force for the purpose of the expedition. The tribe with which Mr. - - and myself were staying, had not sent any men on this war party; but, I suppose to keep their hands in, had attacked one of the two tribes who had, and who were, consequently, much weakened by the absence of so many of their best men. It, howerer, turned out that after a battle-the ferocity of which has seldom been equalled in any country but this-our friends were defeated with a dreadful loss, having inflicted almost as great on the enemy. Peace, however, had afterwards been formally made; but, nevertheless, the news of the return of this expedition was not heard without causing a sensation almost amounting to consternation. The war chief of the party who had been attacked by our friends during his absence, was now, with all his men, within an easy day's march. His road lay right through our vil- 
lage, and it was much to be doubted that he would keep the peace, being one of the most noted war chiefs of New Zealand, and he and his men returning from a successful expedition. All now was uproar and confusion; messengers were running like mad, in all directions, to call in stragglers; the women were carrying fuel and provisions into the pa or fortress of the tribe. This pa was a very well built and strong stockade, composed of three lines of strong fence and ditch, very ingeniously and artificially planned; and, indeed, as good a defence as well could be imagined against an enemy armed only with musketry.

All the men were now working like furies, putting this fort to rights, getting it into fighting order, mending the fences, clearing out the ditches, knocking down houses inside the place, clearing away brushwood and fern all around the outside within musket shot. I was in the thick of it, and worked all day lashing the fence; the fence being of course not nailed, but lashed with toro-toro, a kind of tough creeping plant, like a small rope, which was very strong and well adapted for the purpose. This lashing was about ten or twelve feet from the ground, and a stage had to be erected for the men to stand on. To accomplish this lashing or fastening of the fence well and with expedition required two men, one inside the fence and another outside; all the men therefore worked in pairs, passing the end of the toro-toro from one to the other through the fence of large upright stakes and round a cross piece which 
went all along the fence, by which means the whole was connected into one strong wall. I worked away like fury, just as if I had been born and bred a member of the community; and moreover, not being in those days very particularly famous for what is called prudence, I intended also, circumstances permitting, to fight like fury too, just for the fun of the thing. About a hundred men were employed in this part of the work new lashing the pa. My vis-à-vis in the operation was a respectable old warrior of great experience and approved valour, whose name being turned into English meant "The eater of his own relations." (Be careful not to read rations.) This was quite a different sort of diet from "melons," and he did not bear his name for nothing, as I could tell you if I had time, but I am half mad with haste lashing the pa. I will only say that my comrade was a most bloodthirsty, ferocious, athletic sarage, and his character was depicted in every line of his tattooed face. About twenty men had been sent out to watch the approach of the dreaded visitors. The repairing of the stockade went on all one day and all one night by torchlight and by the light of huge fires lit in the inside. No one thought of sleep. Dogs barking, men shouting, children crying, women screaming, pigs squealing, muskets firing (to see if they were fit for active service and would go off), and above all the doleful tetere sounding. This was a huge wooden trumpet six feet long, which gave forth a groaning moaning sound, like the voice of a 
dying wild bull. Babel, with a dash of Pandemonium, will give a faint idea of the uproar.

All preparations having been at last made, and no further tidings of the enemy, as I may call them, I took a complete survey of the fort, my friend the "Relation Eater" being my companion and explaining to me the design of the whole. I learned something that day; and I, though pretty well "up" in the noble science of fortification, ancient and modern, was obliged to confess to myself that a savage who could neither read or write-who had never heard of Cohorn or Vauban-and who was moreover avowedly a gobbler up of his own relations, could teach me certain practical "dodges" in the defensive art quite weîl worth ǩnowing.

A long shed of palm leaves had been also built at a safe and convenient distance from the fort. This was for the accommodation of the expected visitors, supposing they came in peaceful guise. A whole herd of pigs were also collected and tied to stakes driven into the ground in the rear of the fort. These were intended to feast the coming guests, according to their behaviour.

Towards evening a messenger from a neighbouring friendly tribe arrived to say that next day, about noon, the strangers might be expected; and also that the peace which had been concluded with their tribe during their absence, had been ratified and accepted by them. This was satisfactory intelligence; but, nevertheless, no precaution must be neglected. To be thrown off guard would invite an attack, and 
ensure destruction; everything must be in order; gun cleaning, flint fixing, cartridge making, was going on in all directions; and the outpost at the edge of the forest was not called in. All was active preparation.

The path by which these doubtful friends were coming led through a dense forest and came out on the clear plain about half-a-mile from the pa, which plain continued and extended in every direction around the fortress to about the same distance, so that none could approach unperceived. The outpost of twenty men were stationed at about a couple of hundred yards from the point where the path emerged from the wood; and as the ground sloped considerably from the forest to the fort, the whole intervening space was clearly visible.

Another night of alarm and sleepless expectation, the melancholy moan of the tetere still continuing to hint to any lurking enemy that we were all wide awake; or rather, I should say, to assure him most positively of it, for who could sleep with that diabolical din in his ears? Morning came and an early breakfast was cooked and devoured hurriedly. Then groups of the younger men might be seen here and there fully armed, and "getting up steam" by dancing the war dance, in anticipation of the grand dance of the whole warrior force of the tribe, which, as a matter of course, must be performed in honour of the visitors when they arriced. In honour, but quite as much in intimidation, or an endearour at it, though no one said so. Noon arrived at last. 
Anxious glances are turning from all quarters towards the wood, from which a path is plainly seen winding down the sloping ground towards the pa. The outpost is on the alert. Straggling scouts are out in every direction. All is expectation. Now there is a movement at the outpost. They suddenly spread in an open line, ten yards between each man. One man comes at full speed running towards the pa, jumping and bounding over every impediment. Now something moves in the border of the forest,it is a mass of black heads. Now the men are plainly visible. The whole taua has emerged upon the plain. "Here they come! here they come!" is heard in all directions. The men of the outpost cross the line of march in pretended resistance; they present their guns, make horrid grimaces, dance about like mad baboons, and then fall back with headlong speed to the next advantageous position for making a stand. The taua, however, comes on steadily; they are formed in a solid oblong mass. The chief at the left of the column leads them on. The men are all equipped for immediate action, that is to say, quite naked except their arms and cartridge boxes, which are a warrior's clothes. No one can possibly tell what this peaceful meeting may end in, so all are ready for action at a second's notice. The taua still comes steadily on. As I have said, the men are all stripped for action, but I also notice that the appearance of nakedness is completely taken away by the tattooing, the colour of the skin, and the arms and equipments. The men in fact look much better than 
when dressed in their Maori clothing. Every man, almost without exception, is covered with tattooing from the knees to the waist; the face is also covered with dark spiral lines. Each man has round his middle a belt, to which is fastened two cartridge boxes, one behind and one before; another belt goes over the right shoulder and under the left arm, and from it hangs, on the left side and rather behind, another cartridge box, and under the waist-belt is thrust, behind, at the small of the back, the shorthandled tomahawk for close fight and to finish the wounded. Each cartridge box contains eighteen rounds, and every man has a musket. Altogether this taua is better and more uniformly armed and equipped than ordinary; but they have been amongst the first who got pakehas to trade with them, and are indeed in consequence the terror of $\mathrm{New}$ Zealand. On they come, a set of tall, athletic, heary-made men; they would, I am sure, in the aggregate weigh some tons heavier than the same number of men taken at random from the streets of one of our manufacturing towns. They are now half way across the plain; they keep their formation, a solid oblong, admirably as they advance, but they do not keep step; this causes a very singular appearance at a distance. Instead of the regular marching step of civilized soldiers, which may be observed at any distance, this mass seems to progress towards you with the creeping motion of some great reptile at a distance, and when coming down a sloping ground this effect is quite remarkable. 
The mimic opposition is now discontinued; the outpost rushes in at full speed, the men firing their guns in the air as they run. Takini! takini! is the cry, and out spring three young men, the best runners of our tribe, to perform the ceremony of the taki. They hold in their hands some reeds to represent darts or kokiri. At this moment a tremendous fire of ball cartridge opens from the fort; the balls whistle in every direction, over and around the advancing party, who steadily and gravely come on, not seeming to know that a gun has been fired, though they perfectly well understand that this salute is also a hint of full preparation for any unexpected turn things may take. Now, from the whole female population arises the shrill "haere mai! haere mai!" Mats are waving, guns firing, dogs barking; the chief roaring to "fall in," and form for the war dance. He appears half mad with excitement, anxiety, and something very like apprehension of a sudden onslaught from his friends. In the midst of this horrible uproar off dart three runners. They are not unexpected. Three young men of the taua are seen to tighten their waist-belts, and hand their muskets to their comrades. On go the three young men from the fort. They approach the front of the advancing column; they dance and caper about like mad monkeys, twisting their faces about in the most extraordinary manner, showing the whites of their eyes, and lolling out their tongues. At last, after several feints, they boldly advance within twenty yards of the supposed enemy, and send the reed 
darts flying full in their faces: then they turn and fly as if for life. Instantly, from the stranger ranks, three young men dart forth in eager pursuit; and behind them comes the solid column, rushing on at full speed. Run now, O "Sounding Sea," (Tai Haruru) for the "Black Cloud," (Kapua Mangu) the swiftest of the Rarawa, is at your back; run now, for the honour of your tribe and your own name, run! run! It was an exciting scene. The two famous runners came on at a tremendous pace, the dark mass of armed men following close behind at full speed, keeping their formation admirably, the ground shaking under them as they rushed on. On come the two runners (the others are left behind and disregarded). The pursuer gains upon his man; but they are fast nearing the goal, where, according to Maori custom, the chase must end. Run, "Sounding Sea;" another effort! your tribe are near in full array, and armed for the war dance; their friendly ranks are your refuge; run! run! On came the headlong race. When within about thirty yards of the place where our tribe was now formed in a solid oblong, each man kneeling on one knee, with musket held in both hands, butt to ground, and somewhat sloped to the front, the pursuing native caught at the shoulder of our man, touched it, but could do no more. Here he must stop; to go farther would not be "correct." He will, however, boast everywhere that he has touched the shoulder of the famous "Sounding Sea." Our man has not, however, been caught, which would have been a bad omen. At 
this moment the charging column comes thundering up to where their man is standing; instantly they all kneel upon one knee, holding their guns sloped before their faces, in the manner already described. The élite of the two tribes are now opposite to each other, all armed, all kneeling, and formed in two solid oblong masses, the narrow end of the oblong to the front. Only thirty yards divide them; the front ranks do not gaze on each other; both parties turn their eyes towards the ground, and with heads bent downwards, and a little to one side, appear to listen. All is silence; you might have heard a pin drop. The uproar has turned to a calm; the men are kneeling statues; the chiefs have disappeared; they are in the centre of their tribes. The pakeha is beginning to wonder what will be the end of all this; and also to speculate on the efficacy of the buck shot with which his gun is loaded, and wishes it was ball. Two minutes have elapsed in this solemn silence, the more remarkable as being the first quiet two minutes for the last two days and nights. Suddenly from the extreme rear of the strangers' column is heard a scream-a horrid yell. A savage, of herculean stature, comes, mere in hand, and rushing madly to the front. He seems hunted by all the furies. Bedlam never produced so horrid a visage. Thrice, as he advances, he gives that horrid cry; and thrice the armed tribe give answer with a longdrawn gasping sigh. He is at the front; he jumps into the air, shaking his stone weapon; the whites only of his eyes are visible, giving a most hidcous 
appearance to his face; he shouts the first words of the war song, and instantly his tribe spring from the ground. It would be hard to describe the scene which followed. The roaring chorus of the war song; the horrid grimaces; the eyes all white; the tongues hanging out; the furious yet measured and uniform gesticulation, jumping, and stamping. I felt the ground plainly trembling. At last the war dance ended; and then my tribe, (I find I am already beginning to get Maorified,) starting from the ground like a single man, endeavoured to outdo even their amiable friends' exhibition. They end; then the new-comers perform another demon dance; then my tribe give another. Silence again prevails, and all sit down. Immediately a man from the new arrivals comes to the front of his own party; he runs to and fro; he speaks for his tribe; these are his words:"Peace is made! peace is made! peace is firm! peace is secure! peace! peace! peace!" This man is not a person of any particular consequence in his tribe, but his brother was killed by our people in the battle I have mentioned, and this gives him the right to be the first to proclaim peace. His speech is ended and he "falls in." Some three or four others "follow on the same side." Their speeches are short also, and nearly verbation what the first was. Then who of all the world starts forth from "ours," to speak on the side of "law and order," but my diabolical old acquaintance the "Relation Eater." I had by this time picked up a little Maori, and could partly understand his specch. "Welcome! welcome! 
welcome! peace is made! not till now has there been true peace! I have seen you, and peace is made!" Here he broke out into a song, the chorus of which was taken up by hundreds of voices, and when it ended he made a sudden and very expressive gesture of scattering something with his hands, which was a signal to all present that the ceremonial was at an end for the time. Our tribe at once disappeared into the pa, and at the same instant the strangers broke into a scattered mob, and made for the long shed which had been prepared for their reception, which was quite large enough, and the floor covered thickly with clean rushes to sleep on. About fifty or sixty then started for the border of the forest to bring their clothes and baggage, which had been left there as incumbrances to the movements of the performers in the ceremonials I have described. Part, however, of the "impedimenta" had already arrived on the backs of about thirty boys, women, and old slaves; and I noticed amongst other things some casks of cartridges, which were, as I thought, rather ostentatiously exposed to view.

I soon found the reason my friend of saturnine propensities had closed proceedings so abruptly was, that the tribe had many pressing duties of hospitality to fulfil, and that the heavy talking was to commence next day. I noticed also that to this time there had been no meeting of the chiefs, and, moreover, that the two parties had kept strictly separate-the nearest they had been to each other was thirty yards when the war dancing was going on, and they seemed 
quite glad, when the short speeches were over, to move off to a greater distance from each other.

Soon after the dispersion of the two parties, a firing of muskets was heard in and at the rear of the fort, accompanied by the squeaking, squealing, and dying groans of a whole herd of pigs. Directly afterwards a mob of fellows were seen staggering under the weight of the dead pigs, and proceeding to the long shed already mentioned, in front of which they were flung down, sans-ceremonie, and without a word spoken. I counted sixty-nine large fat pigs flung in one heap, one on the top of the other, before that part of the shed where the principal chief was sitting; twelve were thrown before the interesting savage who had "started" the war dance; and several single porkers were thrown without any remark before certain others of the guests. The parties, however, to whom this compliment was paid sat quistly saying nothing, and hardly appearing to see what was done. Behind the pigs was placed, by the active exertion of two or three hundred people, a heap of potatoes and kumera, in quantity about ten tons, so there was no want of the raw material for a feast.

The pigs and potatocs having been deposited, a train of women appeared-the whole, indeed, of the young and middle-aged women of the tribe. They advanced with a half-dancing half-hopping sort of step, to the time of a wild but not unmusical chant, each woman holding high in both hands a smoking dish of some kind or other of Maori delicacy, hot 
from the oven. The groundwork of this feast appeared to be sweet potatoes and taro, but on the top of each smoking mess was placed either dried shark, eels, mullet, or pork, all "piping hot." This treat was intended to stay our guests' stomachs till they could find time to cook for themselves. The women having placed the dishes, or to speak more correctly, baskets, on the ground before the shed, disappeared; and in a miraculously short time the feast disappeared also, as was proved by seeing the baskets flung in twos, threes, and tens, empty out of the shed.

Next day, pretty early in the morning, I saw our chief (as I must call him for distinction) with a few of the principal men of the tribe, dressed in their best Maori costume, taking their way towards the shed of the visitors. When they got pretty near, a cry of haere mai! hailed them. They went on gravely, and observing where the principal chief was scated, our chief advanced towards him, fell upon his neck embracing him in the most affectionate manner, commenced a tangi, or melancholy sort of ditty, which lasted a full half hour, and during which, both parties, as in duty bound and in compliance with custom, shed floods of tears. How they managed to do it is more than I can tell to this day, except that I suppose you may train a man to do anything. Right well do I know that either party would have almost given his life for a chance to exterminate the other with all his tribe; and twenty-seven years afterwards I saw the two tribes fighting in the very quarrel which was pretended to have becn made up that day. Beíore 
this, however, both these chiefs were dead, and others reigned in their stead. While the tangi was going on between the two principals, the companions of our chief each selected one of the visitors, and rushing into his arms, went through a similar scene. Old "Relation Eater" singled out the horrific savage who had began the war dance, and these two tenderhearted individuals did, for a full half hour, seated on the ground, hanging on each other's necks, give vent to such a chorus of skilfully modulated howling as would have given Momus the blue devils to listen to.

After the tangi was ended, the two tribes seated themselves in a large irregular circle on the plain, and into this circle strode an orator, who, having said his say, was followed by another, and so the greater part of the day was consumed. No arms were to be seen in the hands of either party, except the greenstone mere of the principal chiefs; but I took notice that about thirty of our people never left the nearest gate of the pa, and that their loaded muskets, although out of sight, were close at hand, standing against the fence inside the gate, and I also perceived that under their cloaks or mats they wore their cartridge boxes and tomaharks. This caused me to observe the other party more closely. They also, I perceived, had some forty men sleeping in the shed; these fellows had not removed their cartridge boxes cither, and all their companions' arms were carefully ranged behind them in a row, six or seren deep, against the back wall of the shed.

The speeches of the orators were not rery interest- 
ing, so I took a stroll to a little rising ground at about a hundred yards distance, where a company of natives, better dressed than common, were seated. They had the best sort of ornamented cloaks, and had feathers in their heads, which I already knew "commoners" could not afford to wear, as they were only to be procured some hundreds of miles to the south. I therefore concluded these were magnates or "personages" of some kind or other, and determined to introduce myself. As I approached, one of these splendid individuals nodded to me in a very familiar sort of manner, and I, not to appear rude, returned the salute. I stepped into the circle formed by my new friends, and had just commenced a tena koutou, when a breeze of wind came sighing along the hill-top. My friend nodded again,-his cloak blew to one side. What do I see ?-or rather what do I not see? The head has no body under it! The heads had all been stuck on slender rods, a cross stick tied on to represent the shoulders, and the cloaks thrown over all in such a natural manner as to deceive anyone at a short distance, but a green pakeha, who was not expecting any such matter, to a certainty. I fell back a yard or two, so as to take a full view of this silent circle. I began to feel as if at last I had fallen into strange company. I began to look more closely at my companions, and to try to fancy what their characters in life had been. One had undoubtedly been a warrior; there was something bold and defiant about the whole air of the head. Another was the head of a very old man, 
grey, shrivelled, and wrinkled. I was going on with my observations when I was saluted by a voice from behind with, "Looking at the eds, sir?" It was one of the pakehas formerly mentioned. "Yes," said I, turning round just the least possible thing quicker than ordinary. " "Eds has been a getting scarce," says he. "I should think so," says I. "We an't ad a ed this long time," says he. "The devil!" says I. "One o' them eds has been hurt bad," says he. "I should think all were, rather so," says I. "Oh no, only one on 'em," says he, "the skull is split, and it won't fetch nothin," says he. "Oh, murder! I see, now," says I. "Eds was werry scarce," says he, shaking his own "ed." "Ah!" said I. "They had to tattoo a slave a bit ago," says he, "and the villain ran away, tattooin' and all!" says he. "What?" said I. "Bolted afore he was fit to kill," says he. "Stole off with his own head?" says I. "That's just it," says he. "Capital felony!" says I. "You may say that, sir," says he. "Good morning," said I. I walked away pretty smartly. "Loose notions about heads in this country," said I to myself; and involuntarily putting up my hand to my own, I thought somehow the bump of combativeness felt smaller, or indeed had ranished altogether. "It's all very funny," said I.

I walked down into the plain. I saw in one place a crowd of women, boys, and others. There was a great noise of lamentation going on. I went up to the crowd, and there beheld, lying on a clean mat, which was spread on the ground, another head. A 
number of women were standing in a row before it, screaming, wailing, and quivering their hands about in a most extraordinary manner, and cutting themselves dreadfully with sharp flints and shells. One old woman, in the centre of the group, was one clot of blood from head to feet, and large clots of coagulated blood lay on the ground where she stood. The sight was absolutely horrible, I thought at the time. She was singing or howling a dirge-like wail. In her right hand she held a piece of tuhua, or volcanic glass, as sharp as a razor: this she placed deliberately to her left wrist, drawing it slowly upwards to her left shoulder, the spouting blood following as it went; then from the left shoulder downwards, across the breast to the short ribs on the right side; then the rude but keen knife was shifted from the right hand to the left, placed to the right wrist, drawn upwards to the right shoulder, and so down across the breast to the left side, thus making a bloody cross on the breast; and so the operation went on all the time I was there, the old creature all the time howling in time and measure, and keeping time also with the knife, which at every cut was shifted from one hand to the other, as I have described. She had scored her forehead and cheeks before I came; her face and body was a mere clot of blood, and a little stream was dropping from every finger-a more hideous object could scarcely be conceived. I took notice that the younger women, though they screamed as loud, did not cut near so deep as the old woman, especially about the face. 
This custom has been falling gradually out of use; and when practised now, in these degenerate times, the cutting and maiming is mere form, mere scratching to draw enough blood to swear by: but, in "the good old times," the thing used to be done properly. I often, of late years, have felt quite indignant to see some degenerate hussy making believe with a piece of flint in her hand, but who had no notion of cutting herself up properly as she ought to do. It shows a want of natural affection in the present generation, I think; they refuse to shed tears of blood for their friends as their mothers used to do.

This head, I found on enquiry, was not the head of an enemy. A small party of our friends had been surprised; two brothers were flying for their lives down a hill-side; a shot broke the leg of one of them and he fell; the enemy were close at hand; already the exulting cry " na! na! mate rawa!" was heard; the wounded man cried to the brother, "Do not leave my head a plaything for the foe." There was no time for deliberation. The brother did not deliberate; a few slashes with the tomahawk saved his brother's head, and he escaped with it in his hand, dried it, and brought it home; and the old woman was the mother, - the young ones were cousins. There was no sister, as I heard, when I enquired. All the heads on the hill were heads of enemies, and several of them are now in museums in Europe.

With reference to the knowing remarks of the pakeha who accosted me on the hill on the state of 
the head market, I am bound to remark that my friend Mr. - - never speculated in this " article;" but the skippers of many of the colonial trading schooners were always ready to deal with a man who had " a real good head," and used to commission such men as my companion of the morning to "pick up heads" for them. It is a positive fact that some time after this the head of a live man was sold and paid for beforehand, and afterwards honestly delivered " as per agreement."

The scoundrel slave who had the conscience to run away with his own head after the trouble and expense had been gone to to tattoo it to make it more valuable, is no fiction either. Even in "the good old times" people would sometimes be found to behave in the most dishonest manner. But there are good and bad to be found in all times and places.

Now if there is one thing I hate more than another it is the raw-head-and-bloody-bones style of writing, and in these random reminiscences I shall avoid all particular mention of battles, massacres, and onslaughts, except there be something particularly characteristic of my friend the Maori in them. As for mere hacking and hewing, there has been enough of that to be had in Europe, Asia, and America of late, and very well described too, by numerous " our correspondents." If I should have to fight a single combat or two, just to please the ladies, I shall do my best not to get killed, and hereby promise not to kill any one myself if I possibly can help it. I, however, hope to be excused for the last two or three 
pages, as it was necessary to point out that in the good old times, if one's own head was not sufficient, it was quite practicable to get another.

I must, however, get rid of our visitors. Next day, at daylight, they disappeared: canoes from their own tribe had come to meet them (the old woman with the flint had arrived in these canoes), and they departed sans-ceremonie, taking with them all that was left of the pigs and potatoes which had been given them, and also the "fine lot of eds." Their departure was felt as a great relief, and though it was satisfactory to know peace was made, it was even more so to be well rid of the peacemakers.

Hail, lovely peace, daughter of heaven! meek-eyed inventor of Armstrong guns and Enfield rifles; you of the liquid fire-shell, hail! Shooter at "bulls'eyes," trainer of battalions, killer of wooden Frenchmen, hail! (A bit of fine writing does one good.) Nestling under thy wing, I will scrape sharp the point of my spear with a pipi shell; I will carry fern-root into my pa; I will cure those heads which I have killed in war, or they will spoil and "won't fetch nothin:" for these are thy arts, O peace! 


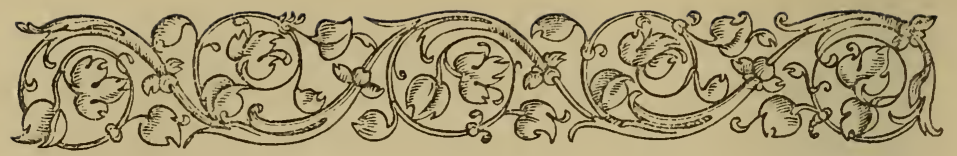

Cifapter IV.

A little affair of "flotsam and jetsam."-Rebellion crushed in the bud.-A Pakeha's house sacked.-Naori law. - A Maori lawsuit.-Afrair thrown into Chancery.

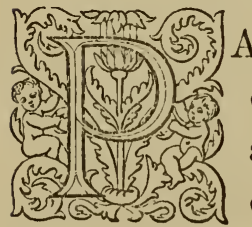

AKEHAS, though precious in the good old times, would sometimes get into awkward scrapes. Accidents, I have times. Some time after the matters I have been recounting happened, two of the pakehas who were "knocking about" Mr. _- 's premises, went fishing. One of them was a very respectable old man-of-war's man; the other was the connoisseur of heads, who, I may as well mention, was thought to be one of that class who never could remember to a nicety how they had come into the country, or where they came from. It so happened that on their return, the little boat, not being well fastened, went adrift in the night, and was cast on shore at about four miles distance, in the dominions of a petty chief who was a sort of vassal or retainer of ours. He did not belong to the tribe, and lived on the land by the 
permission of our chief as a sort of tenant at will. Of late an ill-feeling had grown up between him and the principal chief. The rassal had in fact begun to show some airs of independence, and had collected more men about him than our chief cared to see; but up to this time there had been no regular outbreak between them, possibly because the vassal had not yet sufficient force to declare independence formally. Our chief was however watching for an excuse to fall out with him before he should grow too strong. As soon as it was heard where the boat was, the two men went for it as a matter of course, little thinking that this encroaching vassal would have the insolence to claim the right of "flotsam and jetsam," which belonged to the principal chief, and which was always waived in favour of his pakehas. On arrival, however, at this rebellious chief's dominions, they were informed that it was his intention to stick to the boat until he was paid a "stocking of gunpowder"-meaning a quantity as much as a stocking would hold, which was the regular standard measure in those days in that locality. A stocking of gunpowder! who ever heard of such an awful imposition? The demand was enormous in value and rebellious in principle. The thing must be put an end to at once. The principal chief did not hesitate: rebellion must be crushed in the bud. He at once mustered his whole force (he did not approve of "little wars,") and sent them off under the command of the Relation Eater, who served an ejectment in regular Maori form, by first plundering the village 
and then burning it to ashes; also destroying the cultivation and provisions, and forcing the vassal to decamp with all his people on pain of instant massacre-a thing they did not lose a moment in doing, and I don't think they either eat or slept till they had got fifty miles off, where a tribe related to them received them and gave them a welcome.

Well, about three months after this, about daylight in the morning, I was aroused by a great uproar of men shouting, doors smashing, and women screaming. Up I jumped, and pulled on a few clothes in less time, I am sure, than ever I had done before in my life; out I ran, and at once perceived that Mr. —_'s premises were being sacked by the rebellious vassal, who had returned with about fifty men, and was taking this means of revenging himself for the rough handling he had received from our chief. Men were rushing in mad haste through the smashed windows and doors, loaded with anything and everything they could lay hands on. The chief was stamping against the door of a room in which he was aware the most valuable goods were kept, and shouting for help to break it open. A large canoe was floating close to the house, and was being rapidly filled with plunder. I saw a fat old Maori woman, who was washerwoman to the establishment, being dragged along the ground by a huge fellow, who was trying to tear from her grasp one of my shirts, to which she clung with perfect desperation. I perceived at a glance that the faithful old creature would probably save a sleeve. A long line of similar articles, 
my property, which had graced the taiepa fence the night before, had disappeared. The old man-of-war's man had placed his back exactly opposite to that part of the said fence where hung a certain striped cotton shirt and well scrubbed canvas trowsers, which could belong to no one but himself. He was "hitting out" lustily right and left. Mr. —— had been absent some days on a journey, and the head merchant, as we found after all was over, was hiding under a bed. When the old sailor saw me, he "sang out," in a voice clear as a bell, and calculated to be distinctly heard above the din:- "Hit out, sir, if you please; let's make a fight of it the best we can; our mob will be here in five minutes; Tahuna has run to fetch them." While he thus gave both advice and information, he also set a good example, having delivered just one thump per word or thereabouts. The odds were terrible, but the time was short that I was required to fight; so I at once floored a native who was rushing by me. He fell like a man shot, and I then perceived he was one of our own people who had been employed about the place; so, to balance things, I knocked down another, and then felt myself seized round the waist from behind, by a fellow who seemed to be about as strong as a horse. At this moment I cast an anxious glance around the field of battle. The old Maori woman had, as I expected, sared a good half of my shirt; she had got on the top of an outhouse, and was waving it in a "Sister Anne" sort of manner, and calling to an imaginary friendly host, which she pretended to see adrancing to the rescue. The old sailor had 
fallen under, but not surrendered to, superior force. Three natives had got him down; but it took all they could do to keep him down: he was evidently carrying out his original idea of making a fight of it, and gaining time; - the striped shirt and canvas trowsers still hung proudly on the fence. None of his assailants could spare a second to pull them down. I was kicking and flinging in the endeavour to extricate myself ; or, at least to turn round, so as to carry out a "face to face" policy, which it would be a grand mistake to suppose was not understood long ago in the good old times. I had nearly succeeded, and was thinking what particular form of destruction I should shower on the foe, when a tremendous shout was heard. It was "our mob" coming to the rescue; and, like heroes of old, "sending their voice before them." In an instant both myself and the gallant old tar were released; the enemy dashed on board their canoe, and in another moment were off, darting away before a gale of wind and a fair tide at a rate that put half a mile at least between them and us before our protectors came up. "Load the gun!" cried the sailor-(there was a nine-pound carronade on the cliff before the house, overlooking the river). A cartridge was soon found, and a shot, and the gun loaded. "Slue her a little," cried my now commander; "fetch a fire stick." "Aye, aye, sir" (from self). "Wait a little; that will do-Fire!"-(in a voice as if ordering the discharge of the whole broadside of a three-decker). Bang! The elevation was perfectly correct. The shot struck the water at 
exactly the right distance, and only a few feet to one side. A very few feet more to the right and the shot would have entered the stern of the canoe, and, as she was end on to us, would have killed half the people in her. A miss, however, is as good as a mile off. The canoe disappeared behind a point, and there we were with an army of armed friends around us, who, by making great expedition, had managed to come exactly in time to be too late.

This was a taua muru (a robbing expedition) in revenge for the leader having been cleaned out by our chief, which gave them the right to rob any one connected with, related to, or under the protection of, our chief aforesaid, provided always that they were able. We, on the other hand, had the clear right to kill any of the robbers, which would then have given them the right to kill us; but until we killed some of them, it would not have been "correct" for them to have taken life, so they managed the thing neatly, so that they should have no occasion to do so. The whole proceeding was unobjectionable in every respect, and tika (correct). Had we put in our ninepound shot at the stern of their canoe, it would have been correct also, but as we were not able, we had no right whatever to complain.

The above is good law, and here I may as well inform the New Zealand public that I am going to write the whole law of this land in a book, which I shall call "Ko nga ture;" and as I intend it for the good of both races, I shall mix the two languages up in such a way that ncither can understand; but this 
does not matter, as I shall add a "glossary," in Coptic, to make things clear.

Some time after this, a little incident happened at my friend Mr. - _'s place worth noting. Our chief had, for some time back, a sort of dispute with another magnate, who lived about ten miles off. I really cannot say who was in the right-the arguments on both sides were so nearly balanced, that I should not like to commit myself to a judgment in the case. The question was at last brought to a fair hearing at my friend's house. The arguments on both sides were very forcible, so much so that in the course of the arbitration our chief and thirty of his principal witnesses were shot dead in a heap before my friend's door, and sixty others badly wounded, and my friend's house and store blown up and burnt to ashes. My friend was all but, or indeed, quite ruined, but it would not have been "correct" for him to complain-his loss in goods being far overbalanced by the loss of the tribe in men. He was, however, consoled by hundreds of friends who came in large parties to condole and tangi with him, and who, as was quite correct in such cases, shot and eat all his stock, sheep, pigs, goats, ducks, geese, fowls, \&c., all in high compliment to himself, at which he felt proud, as a well conducted and conditioned pakeha Maori (as he was) should do. He did not, however, survire these honours long, poor fellow. He died, and strange to say, no one knew exactly what was the matter with him-some said it was the climate, they thought. 
After this the land about which this little misunderstanding had arisen, was, so to speak, thrown into chancery, where it has now remained about forty years; but I hear that proceedings are to commence de novo (no allusion to the "new system") next summer, or at farthest the summer after; and as I witnessed the first proceedings, when the case comes on again "may I be there to see."

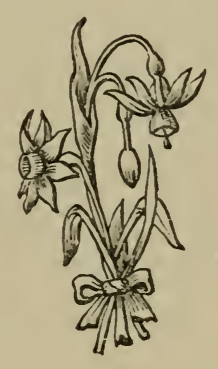




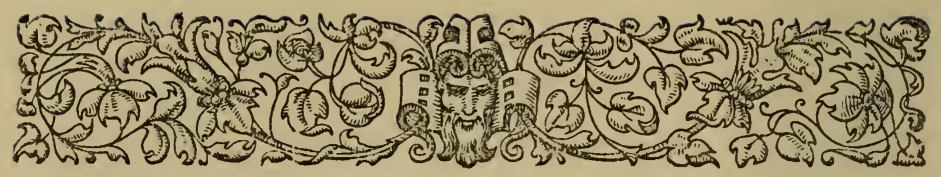

\section{Chapter V.}

Every Englishman's house is his castle.-My estate and castle.-How I purchased my estate.-Native titles to land, of what nature.-Value of land in New Zealand.-Land commissioners.-The triumphs of eloquence.-Magna Charta.

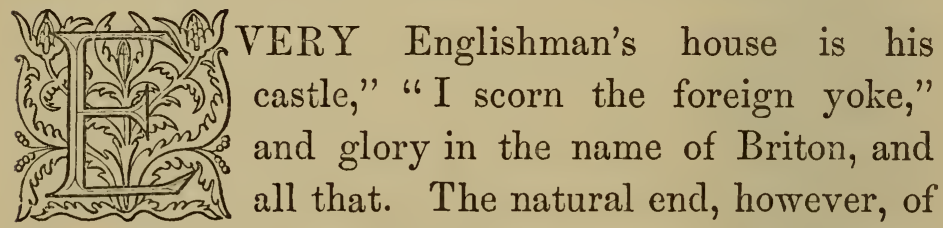
all castles is to be burnt or blown up. In England it is true you can call the constable, and should any foreign power attack you with grinding organ and white mice, you may hope for succours from without, from which cause "castles" in England are more long lived. In New Zealand, however, it is different, as, to the present day, the old system prevails, and castles continue to be disposed of in the natural way, as has been seen lately at Taranaki.

I now purchased a piece of land and built a "castle" for myself. I really can't tell to the present day who I purchased the land from, for there were about fifty different claimants, every one of whom assured me that the other forty-nine were "humbugs," and had no right whatever. The nature of the diffe- 
rent titles of the different claimants was rarious. One man said his ancestors had killed off the first owners; another declared his ancestors had driven off the second party; another man, who seemed to be listened to with more respect than ordinary, declared that his ancestor had been the first possessor of all, and had never been ousted, and that this ancestor was a huge lizard that lived in a cave on the land many ages ago, and sure enough there was the cave to prove it. Besides the principal claims, there were an immense number of secondary onesa sort of latent equities-which had lain dormant until it was known the pakeha had his eye on the land. Some of them seemed to me at the time odd enough. One man required payment because his ancestors, as he affirmed, had exercised the right of catching rats on it, but which he (the claimant) had never done, for the best of reasons, i.e, there were no rats to catch, except indeed pakeha rats, which were plenty enough, but this variety of rodent was not counted as game. Another claimed because his grandfather had been murdered on the land, and-as I am a veracious pakeha-another claimed payment because his grandfather had committed the murder! Then half the country claimed payments of various value, from one fig of tobacco to a musket, on account of a certain wahi tapu, or ancient burying-ground, which was on the land, and in which every one almost had had relations or rather ancestors buried, as they could clearly make out, in old times, though no one had been deposited in it for 
about two hundred years, and the bones of the others had been (as they said) removed long ago to a torere in the mountains. It seemed an awkward circumstance that there was some difference of opinion as to where this same wahi tapu was situated, being, and lying, for in case of my buying the land it was stipulated that I should fence it round and make no use of it, although I had paid for it. (I, however, have put off fencing till the exact boundaries have been made out; and indeed I don't think I shall ever be called on to do so, the fencing proviso having been made, as I now believe, to give a stronger look of reality to the existence of the sacred spot, it having been observed that I had some doubts on the subject. No mention was ever made of it after the payments had been all made, and so I think I may venture to affirm that the existence of the said wahi tapu is of very doubtful authenticity, though it certainly cost me a round "lot of trade.") There was one old man who obstinately persisted in declaring that he, and he alone, was the sole and rightful owner of the land; he seemed also to have a "fixed idea" about certain barrels of gunpowder; but as he did not prove his claim to my satisfaction, and as he had no one to back him, I of course gave him nothing; he nevertheless demanded the gunpowder about once a month for five-and-twenty years, till at last he died of old age, and I am now a landed proprietor, clear of all claims and demands, and have an undeniable right to hold my estate as long as ever I am able. 
It took about three months' negotiation before the purchase of the land could be made; and, indeed, I at one time gave up the idea, as I found it quite impossible to decide who to pay. If I paid one party, the others vowed I should never have possession, and to pay all seemed impossible; so at last I let all parties know that I had made up my mind not to have the land. This, however, turned out to be the first step I had made in the right direction; for, thereupon, all the different claimants agreed amongst themselves to demand a certain quantity of goods, and divide them amongst themselves afterwards. I was glad of this, for I wished to buy the land, as I thought, in case I should ever take a trip to the "colonies," it would look well to be able to talk of "my estate in New Zealand." The day being now come on which I was to make the payment, and all parties present, I then and there handed over to the assembled mob the price of the land, consisting of a great lot of blankets, muskets, tomahawks, tobacco, spades, axes, \&c. \&c.; and received in return a very dirty piece of paper with all their marks on it, I having written the terms of transfer on it in English to my own perfect satisfaction. The cost per acre to me was, as near as can be, about five and a half times what the same quantity of land would have cost me at the same time in Tasmania; but this was not of much importance, as the value of land in New Zealand then, and indeed now, being chiefly imaginary, one could just as easily suppose it to be of a very great value as a very small one; I therefore did not complain of the cost. 
While I am on the subject of land and land titles, I may as well here mention that many years after the purchase of my land I received notice to appear before certain persons called "Land Commissioners," who were part and parcel of the new inventions which had come up soon after the arrival of the first governor, and which are still a trouble to the land. I was informed that I must appear and prove my title to the land I have mentioned, on pain of forfeiture of the same. Now I could not see what right any one could have to plague me in this way, and if I had had no one but the commissioners and two or three hundred men of their tribe to deal with, I should have put my pa in fighting order, and told them to "come on;" for before this time I had had occasion to build a pa, (a little misunderstanding,) and being a regularly naturalized member of a strong tribe, could raise men to defend it at the shortest notice. But somehow these people had cunningly managed to mix up the name of Queen Victoria, God bless her! (no disparagement to King Potatau) in the matter; and I, though a pakeha Maori, am a loyal subject to her Majesty, and will stick up and fight for her as long as ever I can muster a good imitation of courage or a leg to stand upon. This being the case, I made a very unwilling appearance at the court, and explained and defended my title to the land in an oration of four hours and a half's duration; and which, though I was much out of practice, I flatter myself was a good specimen of English rhetoric, and which, for its own merits as well as for another reason which I was not 
a ware of at the time, was listened to by the court with the greatest patience. When I had concluded, and having been asked "if I had any more to say?" I saw the commissioner beginning to count my words, which had been all written, I suppose, in shorthand; and having ascertained how many thousand I had spoken, he handed me a bill, in which I was charged by the word, for every word I had spoken, at the rate of one farthing and one twentieth per word. Oh, Cicero! Oh, Demosthenes! Oh, Pitt, Fox, Burke, Sheridan! Oh, Daniel O'Connell! what would have become of you, if such a stopper had been clapt on your jawing tackle? Fame would never have cracked her trumpet, and "Dan" would never hare raised the rint. For my part I have never recovered the shock. I have since that time become taciturn, and have adopted a Spartan brevity when forced to speak, and I fear I shall never again hare the full swing of my mother tongue. Besides this, I was charged ten shillings each for a little army of witnesses who I had brought by way of being on the sure side-five shillings a head for calling them into court, and five more for "examining" them; said examination consisting of one question each, after which they were told to "be off." I do believe had I brought up a whole tribe, as I had thoughts of doing, the commissioners yould not have minded examining them all. They were, I am bound to say, very civil and polite; one of them told me I was "a damned, infernal, clever fellow, and he should like to see a good many more like me." I hope I am not getting tedious, but this 
business made such an impression on me, that I can't help being too prolix, perhaps, when describing it. I have, however, often since that time had my doubts whether the Queen (God bless her!) got the money or knew half as much of the affair as they wanted to make out. I don't believe it. Our noble Queen would be clean above such a proceeding; and I mean to say it's against Magna Charta, it is! "Justice shall not be sold," saith Magna Charta; and if it's not selling justice to make a loyal pakeha Maori pay for every word he speaks when defending his rights in a court of justice, I don't know what is.

Well, to make matters up, they after some time gave me a title for my land (as if I had not one before); but then, after some years, they made me give it back again, on purpose, as they said, that they might give me a better! But since that time several more years have passed, and I have not got it; so, as these things are now all the fashion, "I wish I may get it."

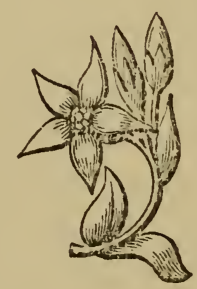




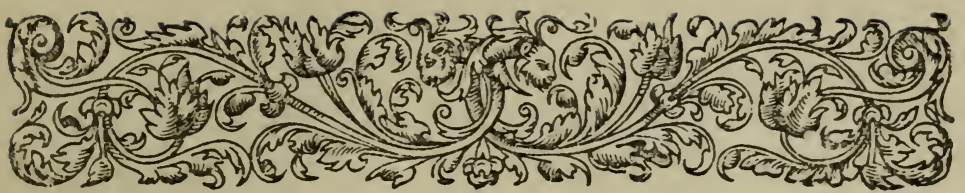

\section{Chapter VI.}

How I kept house.-Maori freebooters.-An ugly customer.The "suaviter in modo."-A single combat to amuse the ladies. -The true Maori gentleman._Character of the Maori people.

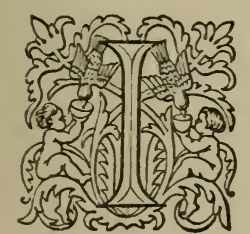

IYEVER yet could get the proper knack of telling a story. Here I am now, a good forty years ahead of where I ought to be, talking of "title deeds" and "land commissioners," things belonging to the new and deplorable state of affairs which began when this country became "a British colony and possession," and also "one of the brightest jewels in the British crown." I must go back.

Having purchased my "estate," I set up housekeeping. My house was a good commodious raupo building; and as I had a princely income of a few hundred a year "in trade," I kept house in a very magnificent and hospitable style. I kept always eight stout paid Maori retainers, the pay being one fig of tobacco per week, and their potatoes, which was about as much more. Their duties were not heary; being chiefly to amuse themselves fishing, wrestling, shooting pigeons, or pig-hunting, with an occasional pull in the boat when I went on a water excursion. Besides 
these paid retainers, there was always about a dozen hangers-on, who considered themselves a part of the establishment, and who, no doubt, managed to live at my expense; but as that expense was merely a few hundredweight of potatoes a week, and an odd pig now and then, it was not perceptible in the good old times. Indeed these hangers-on, as I call them, were necessary; for now and then, in those brave old times, little experiments would be made by certain Maori gentlemen of freebooting propensities, and who were in great want of "British manufactures," to see what could be got by bullying "the pakeha," and to whom a good display of physical force was the only argument worth notice. These gentry generally came from a long distance, made a sudden appearance, and, thanks to my faithful retainers, who, as a matter of course, were all bound to fight for me, though I should have found it hard to get much work out of them, made as sudden a retreat, though on one or two occasions, when my standing army were accidentally absent, I had to do battle single-handed. I think I have promised somewhere that I would perform a single combat for the amusement of the ladies, and so I may as well do it now as at any other time. I shall, therefore, recount a little affair I had with one of these gentry, as it is indeed quite necessary I should, if I am to give any true idea of "the good old times." I must, however, protest against the misdeeds of a few ruffians-human wolves-being charged against the whole of their countrymen. At the time I am speaking of, the only restraint on such people was the fear of 
retaliation, and the consequence was, that often a dare-devil sarage would run a long career of murder, robbery, and outrage before meeting with a check, simply from the terror he inspired, and the "luck" which often accompanies outrageous daring. At a time, however, and in a country like New Zealand, where every man was a fighting man or nothing, these desperadoes, sooner or later, came to grief, being at last invariably shot, or run through the body, by some sturdy freeholder, whose rights they had invaded. I had two friends staying with me, young men who had come to see me from the neighbouring colonies, and to take a summer tour in New Zealand; and it so happened that no less than three times during my absence from home, and when I had taken almost all my people along with me, my castle had been invaded by one of the most notorious ruffians who had ever been an impersonation of, or lived by, the law of force. This interesting specimen of the genus homo had, on the last of these visits, demanded that my friends should hand over to him one pair of blankets; but as the prospectus he produced, with respect to payment, was not at all satisfactory, my friends declined to enter into the speculation, the more particularly as the blankets were mine. Our freebooting acquaintance then, to explain his views more clearly, knocked both my friends down; threatened to kill them both with his tomahawk; then rushed into the bed-room, dragged out all the bedclothes, and burnt them on the kitchen fire.

This last affair was rather displeasing to me. I 
held to the theory that every Englishman's house was his castle, and was moreover rather savage at my guests having been so roughly handled. I in fact began to feel that though I had up to this time managed to hold my own pretty well, I was at last in danger of falling under the imposition of "black mail," and losing my status as an independent potentate-a rangatira of the first water. I then and there declared loudly that it was well for the offender that I had not been at home, and that if ever he tried his tricks with $m e$ he would find out his mistake. These declarations of war, I perceived, were heard by my men in a sort of incredulous silence, (silence in $\mathrm{New}$ Zealand gives dis-sent, ) and though the fellows were stout chaps, who would not mind a row with any ordinary mortal, I verily believe they would have all ran at the first appearance of this redoubted ruffian. Indeed his antecedents had been such as might have almost been their excuse. He had killed several men in fair fight, and had also-as was well known-committed two most diabolical murders, one of which was on his own wife, a fine young woman, whose brains he blew out at half a second's notice for no further provocation than this:- - He was sitting in the verandah of his house, and told her to bring him a light for his pipe. She, being occupied in domestic affairs, said, "Can't you fetch it yourself? I am going for water." She had the calibash in her hand and their infant child on her back. He snatched up his gun and instantly shot her dead on the spot; and I had heard him afterwards describing quite coolly the comical 
way in which her brains had been knocked out by the shot with which the gun was loaded. He also had, for some trifling provocation, lopped off the arm of his own brother or cousin, I forget which, and was, altogether, from his tremendous bodily strength and utter insensibility to danger, about as "ugly a customer" as one would care to meet.

I am now describing a regular Maori ruffian of the good old times, the natural growth of a state of society wherein might was to a very great extent right, and where bodily strength and courage were almost the sole qualities for which a man was respected or valued. He was a bullet-headed, scowling, bowlegged, broad-shouldered, herculean sarage, and all these qualifications combined made him unquestionably "a great rangatira," and, as he had never been defeated, his mana was in full force.

A few weeks after the affair of the blankets, as I was sitting all alone reading a Sydney newspaper, which, being only a year old, was highly interesting, my friends and all my natives having gone on an expedition to haul a large fishing net, who should I see enter the room and squat down on the floor, as if taking permanent possession, but the amiable and highly interesting individual I have taken so much trouble to describe. He said nothing, but his posture and countenance spoke whole rolumes of defiance and murderous intent. He had heard of the threats I had made against him, and there he was, let me turn him out if I dare. That was his meaning-there was no mistaking it. 
I have all my life been an admirer of the suaviter in modo, though it is quite out of place in $\mathrm{New}$ Zealand. If you tell a man-a Maori I mean-in a gentle tone of voice and with a quiet manner, that if he continues a given line of conduct you will begin to commence to knock him down, he simply disbelieves you, and thereby forces you to do that which, if you could have persuaded yourself to have spoken very uncivilly at first, there would have been no occasion for. I have seen many proofs of this, and though I have done my best for many years to improve the understanding of my Maori friends in this particular, I find still there are but very few who can understand at all how it is possible that the suaviter in modo can be combined with the fortiter in re. They in fact can't understand it for some reason perfectly inexplicable to me. It was, however, quite a matter of indifference, I could perceive, how I should open proceedings with my friend, as he evidently meant mischief. "Habit is second nature," so I instinctively took to the suaviter. "Friend," said I, in a very mild tone and with as amiable a smile as I could get up, in spite of a certain clenching of the teeth which somehow came on me at the moment, "my advice to you is to be off." He seemed to nestle himself firmer in his seat, and made no answer but a scowl of defiance. "I am thinking, friend, that this is my house," said I, and springing upon him I placed my foot to his shoulder, and gave a shove which would have sent most people heels over head. Not so, however, with my friend. It shook him, certainly, a 
little; but in an instant, as quick as lightning, and as it appeared with a single motion, he bounded from the ground, flung his mat away over his head, and struck a furious blow at my head with his tomahawk. I escaped instant death by a quickness equal to or greater than his own. My eye was quick, and so was my arm; life was at stake. I caught the tomahawk in full descent; the edge grazed my hand; but my arm, stiffened like a bar of iron, arrested the blow. He made one furious, but ineffectual, effort to tear the tomahawk from my grasp; and then we seized one another round the middle, and struggled like maniacs in the endeavour to dash each other against the boarded floor, I holding on for dear life to the tomahawk, and making desperate efforts to get it from him, but without a chance of success, as it was fastened to his wrist by a strong thong of leather. He was, as I soon found, somewhat stronger than me, and heavier; but I was as active as a cat, and as long-winded as an emu, and very far from weak. At last he got a wiri round my leg; and had it not been for the table on which we both fell, and which, in smashing to pieces, broke our fall, I might have been disabled, and in that case instantly tomahawked. We now rolled over and over on the floor like two mad bulldogs; he trying to bite, and I trying to stun him by dashing his bullet head against the floor. Up again!- still both holding on to the tomahawk. Another furious struggle, in the course of which both our heads, and half our bodies, were dashed through the two glass windows in the room, and every single article of fur- 
niture was reduced to atoms. Down again, rolling like mad, and dancing about amongst the rubbishthe wreck of the house. By this time we were both covered with blood from various wounds, received I don't know how. I had been all this time fighting under a great disadvantage, for my friend was trying to kill me, and I was only trying to disarm and tie him up-a much harder thing than to kill. My reason for going to this trouble was, that as there were no witnesses to the row, if I killed him, I might have had serious difficulties with his tribe. Up again; another terrific tussle for the tomahawk; down again with a crash; and so this life or death battle went on, down and up, up and down, for a full hour. At last I perceived that my friend was getting weaker, and felt that victory was only now a question of time. I, so far from being fatigued, was even stronger. Another desperate wrestling match. I lifted my friend high in my arms, and dashed him, panting, furious, foaming at the mouth, but beaten, against the ground. There he lies; the worshipper of force. His god has deserted him. But no, not yet. He has one more chance, and a fatal one it nearly proved to me. I began to unfasten the tomahawk from his wrist. An odd expression came over his countenance. He spoke for the first time. "Enough, I am beaten; let me rise." Now I had often witnessed the manly and becoming manner in which some Maoris can take defeat, when they have been defeated in what they consider fair play. I had also ceased to fear my friend, and so incautiously let go his left arm. Like 
lightning he snatched at a large carving fork which, unperceived by me, was lying on the floor amongst the smashed furniture and débris of my household effects; his fingers touched the handle, and it rolled away out of his reach, and my life was saved. He then struck me with all his remaining force on the side of the head, causing the blood to flow out of my mouth. One more short struggle, and he was conquered. But now I had at last got angry. The drunkenness, the exhilaration of fight, which comes on some constitutions, was fairly on me. I had also a consciousness that now I must kill my man, or, sooner or later, he would kill me. I thought of the place I would bury him; how I would stun him first with the back of the tomahawk, to prevent too much blood being seen; how I would then carry him off (I could carry two such men norr, easy). I would murder him and cover him up. I unwound the tomahawk from his wrist: he was passive and helpless now. I wished he was stronger, and told him to get up and "die standing," as his countrymen say. I clutched the tomahawk for the coup-de-grâce, (I can't help it, young ladies, the deril is in me,)-at this instant a thundering sound of feet is heard,a whole tribe are coming! Now am I either lost or saved!-saved from doing that which I should afterwards repent, though constrained by necessity to do it. The rush of charging feet comes closer. In an instant comes dashing and smashing through doors and windows, in breathless haste and alarm, a whole tribe of friends. Small ceremony now with my an- 
tagonist. He was dragged by the heels, stamped on, kicked, and thrown half-dead, or nearly quite dead, into his canoe. All the time we had been fighting a little slave imp of a boy belonging to my antagonist had been loading the canoe with my goods and chattels, and had managed to make a very fair plunder of it. These were all now brought back by my friends, except one cloth jacket, which happened to be concealed under the whariki, and which I only mention because I remember that the attempt to recover it some time afterwards cost one of my friends his life. The savage scoundrel who had so nearly done for me, broke two of his ribs, and so otherwise injured him that he never recovered, and died after lingering about a year. My friends were going on a journey, and had called to see me as they passed. They saw the slave boy employed as I have stated, and knowing to whom he belonged had rushed at once to the rescue, little expecting to find me alive. I may as well now dispose of this friend of mine by giving his after history. He for a long time after our fight went continually armed with a double gun, and said he would shoot me wherever he met me; he however had had enough of attacking me in my "castle," and so did not call there any more. I also went continually armed, and took care also to have always some of my people at hand. After this, this fellow committed two more murders, and also killed in fair fight with his own hand the first man in a native battle, in which the numbers on each side were about three hundred, and which I witnessed. The man he 
killed was a remarkably fine young fellow, a great favourite of mine. At last, having attacked and attempted to murder another native, he was shot through the heart by the person he attempted to murder, and fell dead on the spot, and so there died "a great rangatira." His tribe quietly buried him and said no more about it, which showed their sense of right. Had he been killed in what they considered an unjust manner, they would have revenged his death at any cost; but I have no doubt they themselves were glad to get rid of him, for he was a terror to all about him. I have been in many a scrape both by sea and land, but I must confess that I never met a more able hand at an argument than this Maori rangatira.

I have not mentioned my friend's name with whom I had this discussion on the rights of Englishmen, because he has left a son, who is a great rangatira, and who might feel displeased if I was too particular, and I am not quite so able now to carry out a "faceto-face" policy as I was a great many years ago; besides there is a sort of "honour amongst thieves" feeling between myself and my Maori friends on certain matters which we mutually understand are not for the ears of the "new people."

Now, ladies, I call that a fairish good fight, considering no one is killed on either side. I promise to be good in future and to keep the peace, if people will let me; and indeed, I may as well mention, that from that day to this I have nerer had occasion to explain again to a Maori how it is that "every Englishman's house is his castle." 
"Fair play is a jewel;" and I will here, as bound in honour to do, declare that I have met amongst the natives with men who would be a credit to any nation; men on whom nature had plainly stamped the mark of "Noble," of the finest bodily form, quick and intelligent in mind, polite and brave, and capable of the most self-sacrificing acts for the good of others; patient, forbearing, and affectionate in their families; in a word, gentlemen. These men were the more remarkable, as they had grown up surrounded by a set of circumstances of the most unfavourable kind for the development of the qualities of which they were possessed; and I have often looked on with admiration, when $I$ have seen them protesting against, and endeavouring to restrain some of, the dreadful barbarities of their countrymen.

As for the Maori people in general, they are neither so good or so bad as their friends and enemies have painted them, and I suspect are pretty much like what almost any other people would have become, if subjected for ages to the same external circumstances. For ages they have struggled against necessity in all its shapes. This has given to them a remarkable greediness for gain in every visible and immediately tangible form. It has even left its mark on their language. Without the aid of iron the most trifling tool or utensil could only be purchased by an enormously disproportionate outlay of labour in its construction, and, in consequence, became precious to a degree scarcely conceivable by people of civilised and wealthy countries. This great value attached to 
personal property of all kinds, increased proportionately the temptation to plunder; and where no law existed, or could exist, of sufficient force to repress the inclination, every man, as a natural consequence, became a soldier, if it were only for the defence of his own property and that of those who were banded with him-his tribe, or family. From this state of things regular warfare arose, as a matter of course; the military art was studied as a science, and brought to great perfection as applied to the arms used; and a marked military character was given to the people. The necessity of labour, the necessity of warfare, and a temperate climate, gave them strength of body, accompanied by a perseverance and energy of mind perfectly astonishing. With rude and blunt stones they felled the giant kauri-toughest of pines; and from it, in process of time, at an expense of labour, perseverance, and ingenuity perfectly astounding to those who know what it really was-produced, carved, painted, and inlaid, a masterpiece of art, and an object of beauty - the war canoe, capable of carrying a hundred men on a distant expedition, through the boisterous seas surrounding their island.

As a consequence of their warlike habits and character, they are self-possessed and confident in themselves and their own powers, and have much diplomatic finesse and casuistry at command. Their intelligence causes them theoretically to acknowledge the benefits of law, which they see established amongst us, but their hatred of restraint causes them practically to abhor and resist its full enforcement 
amongst themselves. Doubting our professions of friendship, fearing our ultimate designs, led astray by false friends, possessed of that "little learning" which is, in their case, most emphatically "a dangerous thing," divided amongst themselves, - such are the people with whom we are now in contact,such the people to whom, for our own safety and their preservation, we must give new laws and institutions, new habits of life, new ideas, sentiments, and information,-whom we must either civilise or by our mere contact exterminate. How is this to be done? ${ }^{1}$ Let me see. I think I shall answer this question when I am prime minister.

1 Printer's Devil:- How is this to be done?-which? what? -how?-civilise or exterminate? PAKEHA MAORI:-Eaha mau!

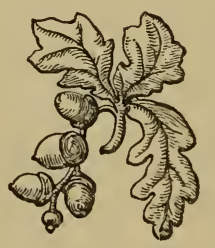




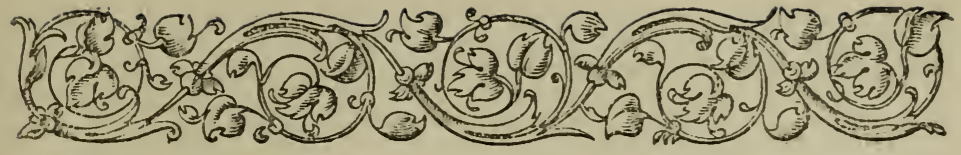

\section{CHAPTER VTII.}

Excitement caused by first contact with Europeans. - The two great institutions of Maori land.-The MIuru.-The Tapu.Instances of legal robbery.-Descriptions and Examples of the Muru._-Profit and loss._Explanation of some of the workings of the law of Muru.

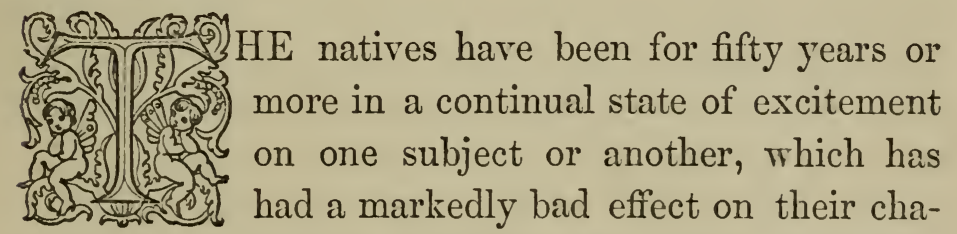
racter and physical condition, as I shall by-and-by take occasion to point out. When the first straggling ships came here the smallest bit of iron was a prize so inestimable that I might be thought to exaggerate were I to tell the bare truth on the subject. The excitement and speculation caused by a ship being seen off the coast was immense. Where would she anchor? What iron could be got from her? Would it be possible to seize her? The oracle was consulted, preparations were made to follow her along the coast, even through an enemy's country, at all risks; and when she disappeared she was not forgotten, and would continue long to be the subject of anxious expectation and speculation. 
After this, regular trading began. The great madness then was for muskets and gunpowder. A furious competition was kept up. Should any tribe fail to procure a stock of these articles as soon as its neighbours, extermination was its probable doom. We may then imagine the excitement, the over-labour, the hardship, the starvation (occasioned by crops neglected whilst labouring to produce flax or other commodity demanded in payment)-I say imagine, but I have seen at least part of it.

After the demand for arms was supplied, came a perfect furore for iron tools, instruments of husbandry, clothing, and all kinds of pakeha manufactures. These things having been quite beyond their means while they were supplying themselves with arms, they were in the most extreme want of them, particularly iron tools. A few years ago the madness ran upon horses and cattle; and now young New Zealand believes in nothing but money, and they are continually tormenting themselves with plans to acquire it in large sums at once, without the trouble of slow and saving industry, which, as applied to the accumulation of money, they neither approve of nor understand; nor will they ever, as a people, take this mode till convinced that money, like everything else. of value, can only be procured as a rule by giving full value for it, either in labour or the produce of labour.

Here I am, I find, again before my story. Right. down to the present time talking of "young New Zealand," and within a hair's-breadth of settling- 
"the Maori difficulty" without having been paid for it, which would have been a great oversight, and contrary to the customs of New Zealand. I must go back.

There were in the old times two great institutions, which reigned with iron rod in Maori land-the Tapu and the Muru. Pakehas who knew no better, called the muru simply "robbery," because the word muru, in its common signification, means to plunder. But I speak of the regular legalized and established system of plundering as penalty for offences, which in a rough way resembled our law by which a man is obliged to pay " damages." Great abuses had, however, crept into this system-so great, indeed, as to render the retention of any sort of moveable property almost an impossibility, and to, in a great measure, discourage the inclination to labour for its acquisition. These great inconveniences were, however, met, or in some degree softened, by an expedient of a peculiarly Maori nature, which I shall byand-by explain. The offences for which people were plundered were sometimes of a nature which, to a mere pakeha, would seem curious. A man's child fell in the fire and was almost burnt to death. The father was immediately plundered to an extent that almost left him without the means of subsistence: fishing nets, canoes, pigs, provisions-all went. His canoe upset, and he and all his family narrowly escaped drowning-some were, perhaps, drowned. He was immediately robbed, and well pummelled with a club into the bargain, if he was not good at the science of self-defence-the club part of the 
ceremony being always fairly administered one against one, and after fair warning given to defend himself. He might be clearing some land for potatoes, burning off the fern, and the fire spreads farther than he intended, and gets into a wahi tapu or burial-ground. No matter whether any one has been buried in it or no for the last hundred years, he is tremendously robbed. In fact, for ten thousand different causes a man might be robbed; and I can really imagine a case in which a man for scratching his own head might be legally robbed. Now, as the enforcers of this law were also the parties who received the damages, as well as the judges of the amount, which in many cases (such as that of the burnt child) would be everything they could by any means lay hands on, it is easy to perceive that under such a system personal property was an evanescent sort of thing altogether. These executions or distraints were never resisted; indeed, in many cases, as I shall explain by-and-by, it would have been felt as a slight, and even an insult, not to be robbed; the sacking of a man's establishment being often taken as a high compliment, especially if his head was broken into the bargain; and to resist the execution would not only have been looked upon as mean and disgraceful in the highest degree, but it would have debarred the contemptible individual from the privilege of robbing his neighbours, which was the compensating expedient I have alluded to. All this may seem a waste of words to my pakeha Maori readers, to whom these things have become such matters of course as 
to be no longer remarkable; but I have remembered that there are so many new people in the country who don't understand the beauty of being knocked down and robbed, that I shall say a few more words on the subject.

The tract of country inhabited by a single tribe might be say from forty to a hundred miles square, and the different villages of the different sections of the tribe would be scattered over this area at different distances from each other. We will, by way of illustrating the working of the muru system, take the case of the burnt child. Soon after the accident it would be heard of in the neighbouring villages; the family of the mother are probably the inhabitants of one of them; they hare, according to the law of muru, the first and greatest right to clean out the afflicted father-a child being considered to belong to the family of the mother more than to that of the father -in fact it is their child, who the father has the rearing of. The child was moreover a promising lump of a boy, the makings of a future warrior, and consequently very valuable to the whole tribe in general, but to the mother's family in particular. "A pretty thing to let him get spoiled." Then he is a boy of good family, a rangatira by birth, and it would never do to let the thing pass without making a noise about it. That would be an insult to the dignity of the families of both father and mother. Decidedly, besides being robbed, the father must be assaulted with the spear. True, he is a famous spearman, and for his own credit must "hurt" some 
one or another if attacked. But this is of no consequence; a flesh wound more or less deep is to be counted on; and then think of the plunder! It is against the law of muru that any one should be killed, and first blood ends the duel. Then the natural affection of all the child's relations is great. They are all in a great state of excitement, and trying to remember how many canoes, and pigs, and other valuable articles, the father has got: for this must be a clean sweep. A strong party is now mustered, headed probably by the brother of the mother of the child. He is a stout chap, and carries a long tough spear. A messenger is sent to the father, to say that the taua muru is coming, and may be expected tomorrow, or the next day. He asks, "Is it a great taua?" "Yes; it is a very great taua indeed." The victim smiles, he feels highly complimented, he is then a man of consequence. His child is also of great consideration; he is thought worthy of a large force being sent to rob him! Now he sets all in motion to prepare a huge feast for the friendly robbers his relations. He may as well be liberal, for his provisions are sure to go, whether or no. Pigs are killed and baked whole, potatoes are piled up in great heaps, all is made ready, he looks out his best spear, and keeps it always ready in his hand. At last the taua appears on a hill half a mile off; then the whole fighting men of the section of the tribe of which he is an important member, collect at his back, all armed with spear and club, to show that they could resist if they would-a thing, however, not to be thought of under the cir- 
cumstances. On comes the taua. The mother begins to cry in proper form; the tribe shout the call of welcome to the approaching robbers; and then with a grand rush, all armed, and looking as if they intended to exterminate all before them, the kai muru appear on the scene. They dance the war dance, which the villagers answer with another. Then the chief's brother-in-law advances, spear in hand, with the most alarming gestures. "Stand up!-stand up! I will kill you this day," is his cry. The defendant is not slow to answer the challenge. A most exciting, and what to a new pakeha would appear a most desperately dangerous, fencing bout with spears instantly commences. The attack and defence are in the highest degree scientific; the spear shafts keep up a continuous rattle; the thrust, and parry, and stroke with the spear shaft follow each other with almost incredible rapidity, and are too rapid to be followed by an unpractised eye. At last the brotherin-law is slightly touched; blood also drops from our chief's thigh. The fight instantly ceases; leaning on their spears, probably a little badinage takes place between them, and then the brother-in-law roars out "murua! murua! murua!" Then the new arrivals commence a regular sack, and the two principals sit down quietly with a few others for a friendly chat, in which the child's name is never mentioned, or the inquiry as to whether he is dead or alive even made. The case I have just described would, however, be one of more than ordinary importance; slighter "accidents and offences" would be atoned for by a 
milder form of operation. But the general effect was to keep personal property circulating from hand to hand pretty briskly, or indeed to convert it into public property; for no man could say who would be the owner of his canoe or blanket in a month's time. Indeed, in that space of time, I once saw a nice coat, which a native had got from the captain of a trading schooner, and which was an article much coveted in those days, pass through the hands, and over the backs, of six different owners, and return, considerably the worse for wear, to the original purchaser; and all these transfers had been made by legal process of muru. I have been oiten myself paid the compliment of being robbed for little accidents occurring in my family, and have several times also, from a feeling of politeness, robbed my Maori friends, though I can't say I was a great gainer by these transactions. I think the greatest haul I ever made was about half a bag of shot, which I thought a famous joke, seeing that I had sold it the day before to the owner for full value. A month after this I was disturbed early in the morning by a voice shouting, "Get up!-get up! I will kill you this day. You have roasted my grandfather. Get up!-stand up!" I, of course, guessed that I had committed some heinous though involuntary offence, and the "stand up" hinted the immediate probable consequences; so out I turned, spear in hand, and who should I see, armed with a bayonet on the end of a long pole, but my friend the umwhile owner of the bag of shot. He came at me with pretended fury, 
made some smart bangs and thrusts, which I parried, and then explained to me that I had "cooked his grandfather;" and that if I did not come down handsome in the way of damages, deeply as he might regret the necessity, his own credit, and the law of muru, compelled him either to sack my house or die in the attempt. I was glad enough to prevent either event, by paying him two whole bags of shot, two blankets, divers fish-hooks, and certain figs of tobacco, which he demanded. I found that I had really and truly committed a most horrid crime. I had on a journey made my fire at the foot of a tree, in the top of which the bones of my friend's grandfather had once been deposited, but from which they had been removed ten years before; the tree caught fire and had burnt down: and I, therefore, by a convenient sort of figure of speech, had "roasted his grandfather," and had to pay the penalty accordingly.

It did not require much financial ability on my part, after a few experiences of this nature, to perceive that I had better avail myself of my privileges as a pakeha, and have nothing further to do with the law of muru-a determination I have kept to strictly. If ever I have unwittingly injured any of my neighbours, I have always made what I considered just compensation, and resisted the muru altogether; and I will say this for my friends, that when any of them have done an accidental piece of mischief, they have, in most cases without being asked, offered to pay for it.

The above slight sketch of the penal kaw of New 
Zealand I present and dedicate to the Law Lords of England, as it might, perhaps, afford some hints for a reform in our own. The only remark I shall have to add is, that if a man killed another, "malice prepense aforethought," the act, in nineteen cases out of twenty, would be either a very meritorious one, or of no consequence whatever; in either of which cases the penal code had, of course, nothing to do in the matter. If, however, a man killed another by accident, in the majority of cases the consequences would be most serious; and not only the involuntary homicide, but every one connected with him, would be plundered of everything they possessed worth taking. This, however, to an English lawyer, may require some explanation, which is as follows:-If a man thought fit to kill his own slave, it was nobody's affair but his own; the law had nothing to do with it. If he killed a man of another tribe, he had nothing to do but declare it was in revenge or retaliation for some aggression, either recent or traditional, by the other tribe, of which examples were never scarce. In this case the action became at once highly meritorious, and his whole tribe would support and defend him to the last extremity. If he, however, killed a man by accident, the slain man would be, as a matter of course, in most instances, one of his ordinary companions-i.e., one of his own tribe. The accidental discharge of a gun often caused death in this way. Then, indeed, the law of muru had full swing, and the wholesale plunder of the criminal and family was the penalty. Murder, as the natives understood it-that 
is to say, the malicious destruction of a man of the same tribe-did not happen as frequently as might be expected; and when it did, went in most cases unpunished; the murderer in general managing to escape to some other section of the tribe where he had relations, who, as he fled to them for protection, were bound to give it, and always ready to do so ; or otherwise he would stand his ground and defy all comers, by means of the strength of his own family or section, who all would defend him and protect him as a mere matter of course; and as the law of utu or lex talionis was the only one which applied in this case, and as, unlike the law of muru, nothing was to be got by enforcing it but hard blows, murder in most cases went unpunished.

[And so, in this day, when a Maori, for some real or fancied injury, or as a means to elevate his name, kills some wretched white man, he nearly always goes unpunished. The Government ask for him to be given up, the tribe refuse, and there is an end of the matter.-Pembroke.] 


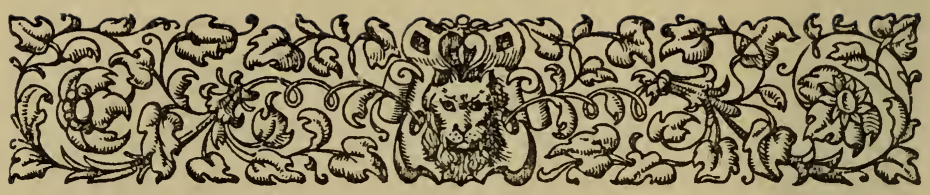

Chapter VIII.

The Muru falling into disuse.-Why?-Examples of the Tapu.-The personal Tapu._Evading the Tapu.-The undertaker's Tapu.-How I got tabooed.-Frightful difficulties.How I got out of them.-The war Tapu.-Maori war customs.

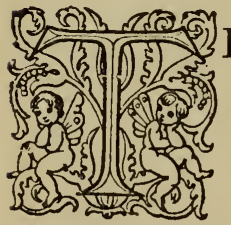

HE law of muru is now but little used, and only on a small scale. The degenerate men of the present day in general content themselves with asking "payment," and after some cavilling as to the amount, it is generally given; but if refused, the case is brought before a native magistrate, and the pleadings on both sides are often such as would astound our most famous barristers, and the decisions of a nature to throw those famous ones by Sancho Panza and Walter the Doubter for ever into the shade.

I think the reason that the muru is so much less practised than formerly is the fact that the natives are now far better supplied with the necessaries and comforts of life than they were many years ago, especially iron tools and utensils, and in consequence the temptation to plunder is proportionately decreased. Money would still be a temptation; but it is so easily 
concealed, and in general they have so little of it, that other means are adopted for its acquisition. When I first saw the natives, the chance of getting an axe or a spade by the short-hand process of muru, or-at a still more remote period-a few wooden implements, or a canoe, was so great that the lucky possessor was continually watched by many eager and observant eyes, in hopes to pick a hole in his coat, by which the muru might be legally brought to bear upon him. I say legally, for the natives always tried to have a sufficient excuse; and I absolutely declare, odd as it may seem, that actual, unauthorized, and inexcusable robbery or theft was less frequent than in any country I ever have been in, though the temptation to steal was a thousandfold greater. The natives of the present day are, howerer, improving in this respect, and, amongst other arts of civilization, are beginning to have rery pretty notions of housebreaking, and have even tried highway robbery, though in a bungling way. The fact is they are just now between two tides. The old institutions which, barbarous and rude as they were, were respected and in some degree useful, are wearing out, and have lost all beneficial effect, and at the same time the laws and usages of civilization have not acquired any sufficient force. This state of things is very unfarourable to the morale of Young New Zealand; but it is likely to change for the better, for it is a maxim of mine that "laws, if not made, will grow."

I must now take some little notice of the other great institution, the tapu. The limits of these flying 
sketches of the good old times will not allow of more than a partial notice of the all-pervading tapu. Earth, air, fire, water, goods and chattels, growing crops, men, women, and children,-everything absolutely was subject to its influence, and a more perplexing puzzle to new pakehas who were continually from ignorance infringing some of its rules, could not be well imagined. The natives, however, made considerable allowance for this ignorance, as well they might, seeing that they themselves, though from infancy to old age enveloped in a cloud of tapu, would sometimes fall into similar scrapes.

The original object of the ordinary tapu seems to have been the preservation of property. Of this nature in a great degree was the ordinary personal tapu. This form of the tapu was permanent, and consisted in a certain sacred character which attached to the person of a chief and never left him. It was his birthright, a part in fact of himself, of which he could not be divested, and which was well understood and recognized at all times as a matter of course. The fighting men and petty chiefs, and every one indeed who could by any means claim the title of rangatira - which in the sense I now use it means gentlemanwere all in some degree more or less possessed of this mysterious quality. It extended or was communicated to all their moveable property, especially to their clothes, weapons, ornaments, and tools, and to everything in fact which they touched. This prevented their chattels from being stolen or mislaid, or spoiled by children, or used or handled in any way by others. 
And as in the old times, as I have before stated, every kind of property of this kind was precious in consequence of the great labour and time necessarily, for want of iron tools, expended in the manufacture, this form of the tapu was of great real service. An infringement of it subjected the offender to various dreadful imaginary punishments, of which deadly sickness was one, as well as to the operation of the law of muru already mentioned. If the transgression was involuntary, the chief, or a priest, or tohunga, could, by a certain mystical ceremony, prevent or remit the doleful and mysterious part of the punishment if he chose, but the civil action, or the robbery by law of muru, would most likely have to take its course, though possibly in a mitigated form, according to the circumstances.

I have stated that the worst part of the punishment of an offence against this form of the tapu was imaginary, but in truth, though imaginary it was not the less a severe punishment. "Conscience makes cowards of us all," and there was scarcely a man in a thousand, if one, who had sufficient resolution to dare the shadowy terrors of the tapu. I actually have seen an instance where the offender, though an involuntary one, was killed stone dead in six hours, by what I considered the effects of his own terrified imagination, but what all the natives at the time believed to be the work of the terrible avenger of the tapu. The case I may as well describe, as it was a strong one, and shows how, when falsehoods are once believed, they will meet with apparent proof from 
accidental circumstances. A chief of very high rank, standing, and mana was on a war expedition; with him were about five hundred men. His own personal tapu was increased twofold, as was that of all the warriors who were with him, by the war tapu. The taua being on a very dangerous expedition, they were over and above the ordinary personal tapu made sacred in the highest degree, and were obliged to observe strictly several mysterious and sacred customs, some of which I may have to explain by-and-by. They were, in fact, as irreverent pakehas used to say, "tabooed an inch thick," and as for the head chief, he was perfectly unapproachable. The expedition halted to dine. The portion of food set apart for the chief, in a neat paro or shallow basket of green flax leaves, was, of course, enough for two or three men, and consequently the greater part remained unconsumed. The party having dined, moved on, and soon after a party of slaves and others, who had been some mile or two in the rear, came up carrying ammunition and baggage. One of the slaves, a stout, hungry fellow, seeing the chief's unfinished dinner, eat it up before asking any questions, and had hardly finished when he was informed by a horror-stricken individual-another slave who had remained behind when the taua had moved on-of the fatal act he had committed. I knew the unfortunate delinquent well. He was remarkable for courage, and had signalized himself in the wars of the tribe. (The able-bodied slaves are always expected to fight in the quarrels of their masters, to do which they are nothing loth.) 
No sooner did he hear the fatal news than he was seized by the most extraordinary convulsions and cramps in the stomach, which never ceased till he died, about sundown the same day. He was a strong man, in the prime of life, and if any pakeha freethinker should have said he was not killed by the tapu of the chief, which had been communicated to the food by contact, he would have been listened to with feelings of contempt for his ignorance and inability to understand plain and direct evidence.

It will be seen at once that this form of the tapu was a great preserver of property. The most valuable articles might, in ordinary circumstances, be left to its protection, in the absence of the owners, for any length of time. It also prevented borrowing and lending in a very great degree; and though much laughed at and grumbled at by unthinking pakehas, who would be always trying to get the natives to give it up, without offering them anything equally effective in its place, or, indeed, knowing its real object or uses, it held its ground in full force for many years, and, in a certain but not so very observable a form, exists still. This form of the tapu, though latent in young folks of rangatira rank, was not supposed to develope itself fully till they had arrived at mature age, and set up house on their own account. The lads and boys "knocked about" amongst the slaves and lower orders, carried fuel or provisions on their backs, and did all those duties which this personal tapu prevented the elders from doing, and which restraint was sometimes very troublesome and inconve- 
nient. A man of any standing could not carry provisions of any kind on his back, or if he did they were rendered tapu, and, in consequence, useless to any one but himself. If he went into the shed used as a kitchen (a thing, however, he would never think of doing except on some great emergency), all the pots, ovens, food, \&c. would be at once rendered useless-none of the cooks or inferior people could make use of them, or partake of anything which had been cooked in them. He might certainly light a little fire in his own house, not for cooking, as that never by any chance could be done in his house, but for warmth; but that, or any other fire, if he should have blown upon it with his breath in lighting it, became at once tapu, and could be used for no common or culinary purpose. Even to light a pipe at it would subject any inferior person, or in many instances an equal, to a terrible attack of the tapu morbus, besides being a slight or affront to the dignity of the person himself. I have seen two or three young men fairly wearing themselves out on a wet day and with bad apparatus trying to make fire to cook with, by rubbing two sticks together, when on a journey, and at the same time there was a roaring fire close at hand at which several rangatira and myself were warming ourselves, but it was tapu, sacred fire-one of the rangatira had made it from his own tinder-box, and blown upon it in lighting it, and as there was not another tinder-box amongst us, fast we must, though hungry as sharks, till common culinary fire could be obtained A native whose personal tapu was perhaps 
of the strongest, might, when at the house of a pakeha, ask for a drink of water; the pakeha, being green, would hand him some water in a glass, or in those days, more probably in a tea-cup; the native would drink the water, and then gravely and quietly break the cup to pieces, or otherwise he would appropriate it by causing it to vanish under his mat. The new pakeha would immediately fly into a passion, to the great astonishment of the native, who considered, as a matter of course, that the cup or glass was, in the estimation of the pakeha, a very worthless article, or he would not have given it into his hand and allowed him to put it to his head, the part most strongly infected by the tapu. Both parties would be surprised and displeased; the native wondering what could have put the pakeha into such a taking, and the pakeha "wondering at the rascal's impudence, and what he meant by it?" The proper line of conduct for the pakeha in the above case made and provided, supposing him to be of a hospitable and obliging disposition, would be to lay hold of some vessel containing about two gallons of water (to allow for waste), hold it up before the native's face, the native would then stoop down and put his hand, bent into the shape of a funnel or conductor for the water, to his mouth; then, from the height of a foot or so, the pakeha would send a cataract of water into the said funnel, and continue the shower till the native gave a slight upward nod of the head, which meant "enough," by which time, from the awkwardness of the pakeha, the two gallons of water would be about expended, half, 
at least, on the top of the native's head, who would not, however, appear to notice the circumstance, and would appreciate the civility of his pakeha friend. I have often drank in this way in the old times; asking for a drink of water at a native village, a native would gravely approach with a calabash, and hold it up before me ready to pour forth its contents; I, of course, cocked my hand and lip in the most knowing manner. If I had laid hold of the calabash and drank in the ordinary way as practised by pakehas, I would have at once fallen in the estimation of all bystanders, and been set down as a tutua-a nobody, who had no tapu or mana about him; a mere scrub of a pakeha, whom any one might eat or drink after without the slightest danger of being poisoned. These things are all changed now, and though I have often in the good old times been tabooed in the most diabolical and dignified manner, there are only a few old men left now who, by little unmistakable signs, I perceive consider it would be very uncivil to act in any way which would suppose my tapu to have disappeared before the influx of new-fangled pakeha notions. Indeed I feel myself sometimes as if I was somehow insensibly partially civilized. What it will all end in, I don't know.

This same personal tapu would even hold its own in some cases against the muru, though not in a sufficiently general manner to seriously affect the operation of that well-enforced law. Its inconveniences were, on the other hand, many, and the expedients resorted to to avoid them were sometimes comical 
enough. I was once going on an excursion with a number of natives; we had two canoes, and one of them started a little before the other. I was with the canoe which had been left behind, and just as we were setting off it was discovered that amongst twenty stout fellows, my companions, there was no one who had a back! —as they expressed it—and, consequently, no one to carry our provisions into the canoe: all the lads, women, and slaves had gone off in the other canoe-all those who had backs-and so there we were left, a very disconsolate lot of rangatira, who could not carry their orn provisions into the canoe, and who at the same time could not go without them. The provisions consisted of sereral heavy baskets of potatoes, some dried sharks, and a large pig baked whole. What was to be done? We were all brought to a full stop, though in a great hurry to go on. We were beginning to think we must give up the expedition altogether, and were very much disappointed accordingly, when a clever fellow, who, had he been bred a lawyer, would have made nothing of driving a mail coach through an act of parliament, set us all to rights in a moment. "I'll tell you what we must do," said he, "we will not carry (pikau) the provisions, we will hiki them." (Hiki is the word in Maori which describes the act of carrying an infant in the arms.) This was a great discovery! A huge handsome fellow seized on the baked pig and dandled it, or hiki'd it, in his arms like an infant; another laid hold of a shark, others took baskets of potatoes, and carrying them in this way deposited them in the canoe. And 
so, having thus evaded the law, we started on our expedition.

I remember another amusing instance in which the inconvenience arising from the tapu was evaded. I must, however, notice that these instances were only evasions of the tapu of the ordinary kind, what I have called the personal tapu, not the more dangerous and dreadful kind connected with the mystic doings of the tolunga, or that other form of tapu connected with the handling of the dead. Indeed, my companions in the instance I have mentioned, though all rangatira, were young men on whom the personal tapu had not arrived at the fullest perfection; it seemed, indeed, sometimes to sit very lightly on them, and I doubt very much if the play upon the words hiki and pikau would have reconciled any of the elders of the tribe to carrying a roasted pig in their arms, or if they did do so, I feel quite certain that no amount of argument would have persuaded the younger men to eat it; as for slaves or women, to look at it would almost be dangerous to them.

The other instance of dodging the law was as follows:-I was the first pakeha who had ever arrived at a certain populous inland village. The whole of the inhabitants were in a great state of commotion and curiosity, for many of them had never seen a pakeha before. As I advanced, the whole juvenile population ran before me at a safe distance of about a hundred yards, eyeing me, as I perceived, with great terror and distrust. At last I suddenly made a charge at them, rolling my eyes and showing my teeth, and 
to see the small savages tumbling over one another, and running for their lives, was something curious, and though my "demonstration" did not continue more than twenty yards, I am sure some of the little villains ran a mile before looking behind to see whether the ferocious monster called a pakeha was gaining on them. They did run! I arrived at the centre of the village, and was conducted to a large house or shed, which had been constructed as a place of reception for visitors, and as a general lounging place for all the inhabitants. It was a whare noa, a house to which, from its general and temporary uses, the tapu was not supposed to attach, I mean, of course, the ordinary personal tapu or tapu rangatira. Any person, however, infected with any of the more serious or extraordinary forms of the tapu entering it, would at once render it uninhabitable. I took my seat. The house was full, and nearly the whole of the rest of the population were blocking up the open front of the large shed, all striving to see the pakeha, and passing to the rear from man to man every word he happened to speak. I could hear them say to the people behind, "The pakeha has stood up!" "Now he has sat dorrn again!" "He has said, how do you all co?" "He has said, this is a nice place of yours!" etc., etc. Now there happened to be at a distance an old gentleman engaged in clearing the weeds from a liumera or sweet potato field, and as the kumera in the old times was the crop on which the natives depended chiefly for support, like all valuable things it was tapu, and the parties who entered the ficld to remove the 
weeds were tapu, pro tem., also. Now one of the effects of this temporary extra tapu was that the parties could not enter any regular dwelling-house, or indeed any house used by others. Now the breach of this rule would not be dangerous in a personal sense, but the effect would be that the crop of sweet potatoes would fail. The industrious individual I have alluded to, hearing the cry of "A pakeha! a pakeha!" from many voices, and having never had an opportunity to examine that variety of the species, or genus homo, flung down his wooden kaheru or weed exterminator and rushed towards the town house before mentioned. What could he do? The tapu forbade his entrance, and the front was so completely blocked up by his admiring neighbours that he could not get sight of the wonderful guest. In these desperate circumstances a bright thought struck him; he would, by a bold and ingenious device, give the tapu the slip. He ran to the back of the house, made with some difficulty a hole in the padded raupo wall, and squeezed his head through it. The elastic wall of raupo closed again around his neck; the tapu was fairly beaten! No one could say he was in the house. He was certainly more out than in, and there, seemingly hanging from or stuck against the wall, remained for hours, with open mouth and wondering eyes, this brazen head, till at last the shades of night obstructing its vision, a rustling noise in the wall of flags and reeds announced the departure of my bodyless admirer.

Some of the forms of the tapu were not to be played with, and were of a most virulent kind. Of this kind 
was the tapu of those who handled the dead, or conveyed the body to its last resting-place. This tapu was, in fact, the uncleanness of the old Jewish law, and lasted about the same time, and was removed in almost the same way. It was a most serious affair. The person who came under this form of the tapu was cut off from all contact, and almost all communication with the human race. He could not enter any house, or come in contact with any person or thing, without utterly bedeviling them. He could not even touch food with his hands, which had become so frightfully tapu or unclean as to be quite useless. Food would be placed for him on the ground, and he would then sit or kneel down, and, with his hands carefully held behind his back, would gnaw it in the best way he could. In some cases he would be fed by another person, who, with outstretched arm, would manage to do it without touching the tapu'd individual; but this feeder was subjected to many and severe restrictions, not much less onerous than those to which the other was subject. In almost every populous native village there was a person who, probably for the sake of immunity from labour, or from being good for nothing else, took up the undertaking business as a regular profession, and, in consequence, was never for a moment, for years together, clear of the horrid inconveniences of the tapu, as well as its dangers. One of these people might be easily recognized, after a little experience, even by a pakeha. Old, withered, haggard, clothed in the most miserable rags, daubed all over from head to foot with red paint (the native 
funereal colour), made of stinking shark oil and red ochre mixed, keeping always at a distance, silent and solitary, often half insane, he might be seen sitting motionless all day at a distance, forty or fifty yards from the common path or thoroughfare of the village. There, under the "lee" of a bush, or tuft of flax, gazing silently, and with "lack-lustre eye," on the busy doings of the Maori world, of which he was hardly to be called a member. Twice a day some food would be thrown on the ground before him, to gnaw as best he might, without the use of hands; and at night, tightening his greasy rags around him, he would crawl into some miserable lair of leaves and rubbish, there, cold, half-starved, miserable, and dirty, to pass, in fitful ghost-haunted slumbers, a wretched night, as prelude to another wretched day. It requires, they say, all sorts of people to make a world; and I have often thought, in observing one of these miserable objects, that his or her's was the very lowest ebb to which a human being's prospects in life could be brought by adverse fate. When I met, or rather saw, a female practitioner, I fairly ran for it; and so, believing my readers to be equally tender-hearted, I shall not venture on any more description, but merely say that the man undertaker, such as I have described him, would be taken for Apollo if seen in one of these hag's company.

What will my kind reader say when I tell him that I myself once got tapu'd with this same horrible, horrible, most horrible style of tapu? I hold it to be a fact that there is not one man in New Zealand but myself who has a clear understanding of what the 
word "excommunication" means, and I did not understand what it meant till I got tapu'd. I was returning with about sixty men from a journey along the rest coast. I was a short distance in advance of the party, when I came to where the side of a hill had fallen down on to the beach, and exposed a number of human bones. There was a large skull rolling about in the water. I took up this skull without consideration, carried it to the side of the hill, scraped a hole, and covered it up. Just as I had finished covering it up, up came my friends, and I saw at once, by the astonishment and dismay depicted on their countenances, that I had committed some most unfortunate act. They soon let me know that the hill had been a burying-place of their tribe, and jumped at once to the conclusion that the skull was the skull of one of their most famous chiefs, whose name they told me, informing me also that I was no 1 nger fit company for human beings, and begging me to fall to the rear and keep my distance. They told me all this from a very respectful distance, and if I made a step towards them, they all ran as if I had been infected by the plague. This was an awkward state of things, but as it could not be helped, I roted myself tapu, and kept clear of my friends till night. At night when they camped I was obliged to take my solitary abode at a distance, under shelter of a rock. When the erening meal was cooked, they brought me a fair allowance, and set it down at a respectful distance from where I sat, fully expecting; I suppose, that I should bob at it as Maori kai tango atua or undertakers are wont to do. I had, however, no idea of 
any such proceeding; and pulling out my knife proceeded to operate in the usual manner. I was checked by an exclamation of horror and surprise from the whole band, "Oh, what are you about, you are not going to touch food with your hands?" "Indeed, but I am," said I, and stretched out my hand. Here another scream-"You must not do that, it's the worst of all things; one of us will feed you; it's wrong, wrong, very wrong!" "Oh, bother," said I, and fell to at once. I declare positively I had no sooner done so than I felt sorry. The expression of horror, contempt, and pity observable in their faces, convinced me that I had not only offended and hurt their feelings, but that I had lowered myself greatly in their estimation. Certainly I was a pakeha, and pakehas will do most unaccountable things, and may be, in ordinary cases, excused; but this, I saw at once, was an act which, to my friends, seemed the ne plus ultra of abomination. I now can well understand that I must have, sitting there eating my potatoes, appeared to them a ghoul, a vampire-worse than even one of their own dreadful atua, who, at the command of a witch, or to avenge some breach of the tapu, enters into a man's body and slowly eats away his vitals. I can see it now, and understand what a frightful object I must have appeared. My friends broke up their camp at once, not feeling sure, after what I had done, but I might walk in amongst them in the night, when they were asleep, and bedevil them all. They marched all night, and in the morning came to my house, where they spread consternation 
and dismay amongst my household by telling them in what a condition I was coming home. The whole of my establishment at this time being natives, they ran at once; and when I got home next evening, hungry and rexed, there was not a soul to be seen. The house and kitchen were shut up, fires out, and, as I fancied, everything looked dreary and uncomfortable. If only a dog had come and wagged his tail in welcome, it would have been something; but even my dog was gone. Certainly there was an old tom cat, but I hate cats, there is no sincerity in them, and so I had kicked this old tom on principle whenever he came in my way, and now, when he saw me, he ran for his life into the bush. The instinct of a hungry man sent me into the kitchen; there was nothing eatable to be seen but a raw leg of pork, and the fire was out. I now began to suspect that this attempt of mine to look down the tapu would fail, and that I should remain excommunicated for some frightfully indefinite period. I began to think of Robinson Crusoe, and to wonder if I could hold out as well as he did. Then I looked hard at the leg of pork. The idea that I must cook for myself brought home to me the fact more forcibly than anything else how I had "fallen from my high estate" - cooking being the very last thing a rangatira can turn his hand to. But why should I have anything more to do with cooking? Was I not cast off and repudiated by the human race? (A horrible misanthropy was fast taking hold of me.) Why should I not tear my leg of pork raw, like a wolf? "I will run a muck!" 
suddenly said I. "I wonder how many I can kill before they 'bag' me? I will kill, kill, kill! but-I must have some supper."

I soon made a fire, and after a little rummaging found the matériel for a good meal. My cooking was not so bad either, I thought; but certainly hunger is not hard to please in this respect, and I had eaten nothing since the diabolical meal of the preceding evening, and had travelled more than twenty miles. I washed my hands six or seven times, scrubbing away and muttering with an intonation that would have been a fortune to a tragic actor. "Out, damned spot;" and so, after having washed and dried my hands, looked at them, returned, and washed again, again washed, and so on several times, I sat down and demolished two days' allowance. After which, reclining before the fire with my pipe and a blanket over my shoulders, a more kindly feeling towards my fellow men stole gradually upon me. "I wonder," said I to myself, "how long this devilish tapu will last! I wonder if there is to be any end at all to it! I won't run a muck for a week, at all events, till I see what may turn up. Confounded plague though to have to cook!" Having resolved as above, not to take any one's life for a week, I felt more patient. Four days passed somehow or another, and on the morning of the fifth, to my extreme delight, I saw a small canoe, pulled by one man, landing on the beach before the house. He fastened his canoe and advanced towards the kitchen, which was detached from the house, and which, in the late deplorable 
state of affairs, had become my regular residence. I sat in the doorway, and soon perceived that my visitor was a famous tohunga, or priest, and who also had the reputation of being a witch of no ordinary dimensions. He was an old, grave, stolid-looking savage, with one eye, the other had been knocked out long ago in a fight before he turned parson. On he came, with a slow, measured step, slightly gesticulating with one hand, and holding in the other a very small basket, not more than nine or ten inches long. He came on, mumbling and grumbling a perfectly unintelligible karakia or incantation. I guessed at once he was coming to disenchant me, and prepared my mind to submit to any conditions or ceremonial he should think fit to impose. My old friend came gravely up, and putting his hand into the little basket pulled out a baked kumera, saying, "He kai mau." I of course accepted the offered food, took a bite, and as I ate he mumbled his incantation over me. I remember I felt a curious sensation at the time, like what I fancied a man must feel who had just sold himself, body and bones, to the devil. For a moment I asked myself the question whether I was not actually being then and there handed over to the powers of darkness. The thought startled me. There was I, an unworthy but believing member of the Church of England as by Parliament established, "knuckling down" abjectly to the ministration of a ferocious old cannibal, wizard, sorcerer, high priest, -as it appeared very probable,-to Satan himself. "Blacken his remaining eye! knock him over and 
run the country!" whispered quite plainly in my ear my guardian angel, or else a little impulsive sprite who often made suggestions to me in those days. For a couple of seconds the sorcerer's eye was in desperate danger; but just in those moments the ceremony, or at least this most objectionable part of it, came to an end. He stood back and said, "Have you been in the house?" Fortunately I had presence of mind enough to forget that I had, and said, "No." "Throw out all those pots and kettles." I saw it was no use to resist-so out they went. "Fling out those dishes" was the next command. "The dishes?-they will break." "I am going to break them all." Capital fun this-out go the dishes; "and may the —-." I fear I was about to say something bad. "Fling out those knives, and those things with sharp points" - (the old villain did not know what to call the forks!)- " and those shells with handles to them "-(spoons!)_-"out with everything." The last sweeping order is obeyed and the kitchen is fairly empty. The worst is over now at last, thank goodness, said I to myself. "Strip off all your clothes." "What? strip naked! you desperate old thief-mind your eye." Human patience could bear no more. Out I jumped. I did "strip." Off came my jacket. "How would you prefer being killed, old ruffian? can you do anything in this way?" (Here a pugilistic demonstration.) "Strip! he doesn't mean to give me five dozen, does he?" said I, rather bewildered, and looking sharp to see if he had anything like an instrument of flagellation in 
his possession. "Come on! what are you waiting for?" said I. In those days, when labouring under what Dickens calls the "description of temporary insanity which arises from a sense of injury," I always involuntarily fell back upon my mother tongue, which in this case was perhaps fortunate, as my necromantic old friend did not understand the full force of my eloquence. He could not, however, mistake my warlike and rebellious attitude, and could see clearly I was going into one of those most unaccountable rages that pakehas were liable to fly into, without any imaginable cause. "Boy," said he, gravely and quietly, and without seeming to notice my very noticeable declaration of war and independence, "don't act foolishly; don't go mad. No one will ever come near you while you have those clothes. You will be miserable here by yourself. And what is the use of being angry? what will anger do for you?" The perfect coolness of my old friend, the complete disregard he paid to my explosion of wrath, as well as his reasoning, began to make me feel a little disconcerted. He evidently had come with the purpose and intention to get me out of a very awkward scrape. I began also to feel that, looking at the affair from his point of view, I was just possibly not making a very respectable figure; and then, if I understood him rightly, there would be no flogging. "Well," said I, at last, "Fate compels; to fate, and not old Hurlothrumbo there, I yield-so here goes." Let me not dwell upon the humiliating concession to the powers of tapu. Suffice it to say, I disrobed, and received 
permission to enter my own house in search of other garments. When I came out again, my old friend was sitting down with a stone in his hand, battering the last pot to pieces, and looking as if he was performing a very meritorious action. He carried away all the smashed kitchen utensils and my clothes in baskets, and deposited them in a thicket at a considerable distance from the house. (I stole the knives, forks, and spoons back again some time after, as he had not broken them.) He then bid me good-bye, and the same evening all my household came flocking back; but years passed before any one but myself would go into the kitchen, and I had to build another. And for several years also I could observe, by the respectable distance kept by young natives and servants, and the nervous manner with which they avoided my pipe in particular, that they considered I had not been as completely purified from the tapu tango atua as I might have been. I now am aware, that in consideration of my being a pakeha, and also perhaps, lest driven to desperation, I should run away entirely, which would have been looked upon as a great misfortune to the tribe, I was let off very easy, and might therefore be supposed to retain some tinge of the dreadful infection.

Besides these descriptions of tapu, there were many others. There was the war tapu, which in itself included fifty different "sacred customs," one of which was this-that often when the fighting men left the pa or camp, they being themselves made tapu, or sacred, as in this particular case the word 
means, all those who remained behind, old men, women, slaves, and all non-combatants were obliged strictly to fast while the warriors were fighting; and, indeed, from the time they left the camp till their return, eren to smoke a pipe would be a breach of this rule. These war customs, as well as other forms of the tapu, are evidently derived from a very ancient religion, and did not take their rise in this country. I shall probably, some of these days, treat of them at more length, and endeavour to trace them to their source.

Sacrifices were often made to the war demon, and I know of one instance in which, when a tribe were surrounded by an orerwhelming force of their enemies, and had nothing but extermination, immediate and unrelenting, before them, the war chief cut out the heart of his own son as an offering for victory, and then he and his tribe, with the fury of despair and the courage of fanatics, rushed upon the foe, defeated them with terrific slaughter, and the war demon had much praise, and many men were eaten.

The warriors, when on a dangerous expedition, also observed strictly the custom to which allusion is made. 1 Samuel, xxi. 4-5. 


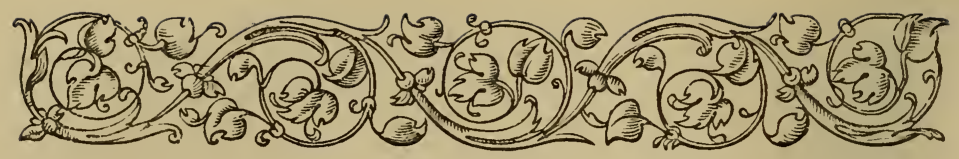

\section{Chapter IX.}

The Tapu Tohunga.-The Maori oracle.-Responses of the oracle.-Priestcraft.

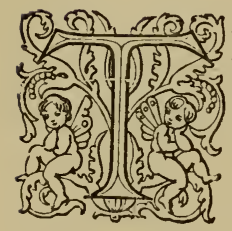

HEN came the tapu tohunga, or priest's tapu, a quite different kind or form of tapu from those which I have spoken of. These tolunga presided over all those ceremonies and customs which had something approaching to a religious character. They also pretended to the power, by means of certain familiar spirits, to foretell future events, and even in some cases to control them. The belief in the power of these tohunga to foretell events was very strong, and the incredulous pakeha who laughed at them was thought a person quite incapable of understanding plain evidence. I must allow that some of their predictions were of a most daring nature, and happening to turn out perfectly successful, there may be some excuse for an ignorant people believing in them. Most of these predictions were, however, given, like the oracles of old, in terms which would admit a double meaning, and secure the character of the soothsayer no matter how the event turned out. It is also 
remarkable that these tohunga did not pretend to divine future events by any knowledge or power exist ing in themselves; they pretended to be for the time inspired by the familiar spirit, and passive in his hands. This spirit "entered into" them, and, on being questioned, gave a response in a sort of halfwhistling, half-articulate voice, supposed to be the proper language of spirits; and I have known a tolunga who, having made a false prediction, laid the blame on the "tricksey spirit," who he said had purposely spoken false for certain good and sufficient spiritual reasons, which he then explained. Amongst the fading customs and beliefs of the good old times the tohunga still holds his ground, and the oracle is as often consulted, though not so openly, as it was a hundred years ago, and is as firmly believed in, and this by natives who are professed Christians; and the inquiries are often on subjects of the most vital importance to the welfare of the colony. A certain tohunga has even quite lately, to my certain knowledge, been paid a large sum of money to do a miracle! I saw the money paid, and I saw the miracle. And the miracle was a good enough sort of miracle, as miracles go in these times. The natives know we laugh at their belief in these things. They would much rather we were angry, for then they would defy us; but as we simply laugh at their credulity, they do all they can to conceal it from us; but nevertheless the chiefs, on all matters of importance, continue to consult the Maori oracle.

I shall give two instances of predictions which came 
under my own observation, and which will show how much the same priestcraft has been in all times.

A man-a petty chief-had a serious quarrel with his relations, left his tribe, and went to a distant part of the country, saying that he cast them off, and would never return. After a time the relations became both uneasy at his absence and sorry for the disagreement. The presence of the head of the family was also of consequence to them. They therefore inquired of the oracle if he would return. At night the tohunga invoked the familiar spirit, he became inspired, and in a sort of hollow whistle came the words of fate:- " He will return, but yet not return." This response was given several times, and then the spirit departed, leaving the priest or tohunga to the guidance of his own unaided wits. No one could understand the meaning of the response. The priest himself said he could make nothing of it. The spirit of course knew his own meaning; but all agreed that, whatever that meaning was, it would turn out true. Now the conclusion of this story is rather extraordinary. Some time after this several of the chief's relations went to offer reconciliation and to endeavour to persuade him to return home. Six months afterwards they returned, bringing him along with them a corpse; they had found him dying, and carried his body home. Now all knew the meaning of the words of the oracle, "He will return, but yet not return."

Another instance, which I witnessed myself, was as follows :-A captain of a large ship had run away 
with a Maori girl; or a Maori girl had run away with a ship captain; I should not like to swear which is the proper form of expression; and the relations, as in such cases happens in most countries, thought it incumbent on them to get into a great taking, and make as much noise as possible about the matter. Off they set to the tolunga; I happened to be at his place at the time, and saw and heard all I am about to recount. The relations of the girl did not merely confine themselves to asking questions, they demanded active assistance. The ship had gone to sea loaded for a long royage. The fugitives had fairly escaped; and what the relations wanted was that the atua, or familiar spirit of the tohunga, should bring the ship back into port, so that they might have an opportunity to recover the lost ornament of the family. I heard the whole. The priest hummed and hawed. "He did not know, could not say. We should hear what the 'boy' would say. $\mathrm{He}$ would do as he liked. Could not compel him;" and so forth. At night all assembled in the house where the priest usually performed. All was expectation. I saw I was de trop in the opinion of our soothsayer; in fact, I had got the name of an infidel (which I have since taken care to get rid of), and the spirit was unwilling to enter the company of unbelievers. My friend the priest hinted to me politely that a nice bed had been made for me in the next house. I thanked him in the most approved Maori fashion, but said I was "very comfortable where I was;" and, suiting the action to the word, rolled my cloak about me, and 
lay down on the rushes with which the floor was covered. About midnight I heard the spirit saluting the guests, and they saluting him; and I also noticed they hailed him as "relation," and then gravely preferred the request that he would "drive back the ship which had stolen his cousin." The response, after a short time, came in the hollow, mysterious, whistling voice,-—"The ship's nose I will batter out on the great sea." This answer was repeated several times, and then the spirit departed and would not be recalled. The rest of the night was spent in conjecturing what could be the meaning of these words. All agreed that there must be more in them than met the ear; but no one could say it was a clear concession of the request made. As for the priest, he said he could not understand it, and that "the spirit was a great rogue "-a koroke hangareka. He, however, kept throwing out hints now and then that something more than common was meant, and talked generally in the "we shall see" style. Now here comes the end of the affair. About ten days after this in comes the ship. She had been "battered" with a vengeance. She had been met by a terrible gale when a couple of hundred miles off the land, and had sprung a leak in the bow. The bow in Maori is called the "nose" (ihu). The vessel had been in great danger, and had been actually forced to run for the nearest port, which happened to be the one she had left. Now, after such a coincidence as this, I can hardly blame the ignorant natives for believing in the oracle, for I actually caught myself 
quoting, "Can the devil speak truth?" Indeed I have in the good old times known several pakehas who "thought there was something in it," and two who formally and believingly consulted the oracle, and paid a high donceur to the priest.

I shall give one more instance of the response of the Maori oracle. A certain northern tribe, noted for their valour, but not very numerous, sent the whole of their best men on a war expedition to the south. This happened about forty years ago. Before the taua started the oracle was consulted, and the answer to the question, "Shall this expedition be successful?" came. "A desolate country!-a desolate country!-a desolate country!" This the eager warriors accepted as a most favourable response. They said the enemy's country would be desolated. It, however, so turned out that they were all exterminated to a man, and the miserable remnant of their tribe, weakened and rendered helpless by their loss, became a prey to their more immediate neighbours, lost their lands, and have ceased from that day to be heard of as an independent tribe. So, in fact, it was the country of the eager inquirers which was laid "desolate." Every one praised the oracle, and its character was held higher than ever.

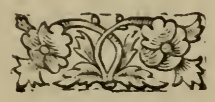




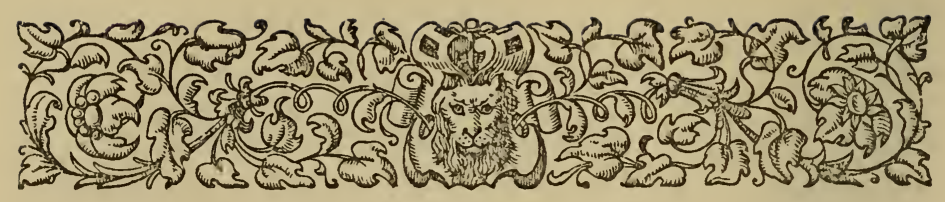

\section{Chapter X.}

The priest erokes a spirit.-The consequences.-A Maori tragedy.-The "Tohunga" again.

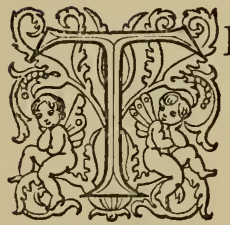

HESE priests or tohunga would, and dc to this hour, undertake to call up the spirit of any dead person, if paid for the same. I have seen many of these exhibitions, but one instance will suffice as an example.

A young chief, who had been very popular and greatly respected in his tribe, had been killed in battle, and, at the request of several of his nearest friends, the tohunga had promised on a certain night to call up his spirit to speak to them, and answer certain questions they wished to put. The priest was to come to the village of the relations, and the interview was to take place in a large house common to all the population. This young man had been a great friend of mine; and so, the day before the event, I was sent to by his relations, and told that an opportunity offered of conversing with my friend once more. I was not much inclined to bear a part in such outrageous mummery, but curiosity caused me to go. Now it is necessary to remark that this young chief 
Tas a man in advance of his times and people in many respects. He was the first of his tribe who could read and write; and, amongst other unusual things for a native to do, he kept a register of deaths and births, and a journal of any remarkable events which happened in the tribe. Now this book was lost. No one could find it, although his friends had searched unceasingly for it, as it contained many matters of interest, and also they wished to preserve it for his sake. I also wished to get it, and had often inquired if it had been found, but had always been answered in the negative. The appointed time came, and at night we all met the priest in the large house I have mentioned. Fires were lit, which gave an uncertain, flickering light. The priest retired to the darkest corner. All was expectation, and the silence was only broken by the sobbing of the sister and other female relations of the dead man. They seemed to be, and indeed were, in an agony of excitement, agitation, and grief. This state of things continued for a long time, and I began to feel in a way surprising to myself, as if there was something real in the matter. The heart-breaking sobs of the women, and the grare and solemn silence of the men, convinced me that, to them at least, this was a serious matter. I saw the brother of the dead man now and then wiping the tears in silence from his eyes. I wished I had not come, for I felt that any unintentional symptom of incredulity on my part would shock and hurt the feelings of my friends extremely; and yet, whilst feeling thus, I felt myself more and more near to believing in 
the deception about to be practised. The real grief, and also the general undoubting faith, in all around me, had this effect. We were all seated on the rushstrewn floor, about thirty persons. The door was shut; the fire had burnt down, leaving nothing but glowing charcoal. The room was oppressively hot. The light was little better than darkness, and the part of the room in which the tolunga sat was now in perfect darkness. Suddenly, without the slightest warning, a voice came out of the darkness. "Salutation!salutation to you all!-salutation!- salutation to you, my tribe!-family, I salute you!-friends, I salute you !-friend, my pakeha friend, I salute you!" The high-handed, daring imposture was successful; our feelings were taken by storm. A cry expressive of affection and despair, such as was not good to hear, came from the sister of the dead chief, a fine, stately, and really handsome woman of about five-and-twenty. She was rushing, with both arms extended, into the dark, in the direction from whence the voice came. She was instantly seized round the waist and restrained by her brother by main force, till moaning and fainting she lay still on the ground. At the same instant another female voice was heard from a young girl who was held by the wrists by two young men, her brothers. "Is it you?-is it you?-truly is it you?aue! aue! they hold me, they restrain me; wonder not that I have not followed you; they restrain me, they watch me, but I go to you. The sun shall not rise, the sun shall not rise, aue! aue!" Here she fell insensible on the rush floor, and with the sister was 
carried out. The remaining women were all weeping and exclaiming, but were silenced by the men, who were themselves nearly as much excited, though not so clamorous. I, however, did notice two old men, who sat close to me, were not in the slightest degree moved in any way, though they did not seem at all incredulous, but quite the contrary. The spirit spoke again. "Speak to me, the tribe!-speak to me, the family!-speak to me, the pakeha!" The "pakeha," however, was not at the moment inclined for conversation. The deep distress of the two women, the evident belief of all around him of the presence of the spirit, the "darkness visible," the novelty of the scene, gave rise to a state of feeling not favourable to the conversational powers. Besides, I felt reluctant to give too much apparent credence to an imposture, which at the rery same time, by some strange impulse, I felt half ready to give way to. At last the brother spoke. "How is it with you? - is it well with you in that country?" The answer came-(the roice all through, it is to be remembered, was not the voice of the tohunga, but a strange melancholy sound, like the sound of the wind blowing into a hollow vessel), - "It is well with me; my place is a good place." The brother spoke again. "Have you seen - and _- and —_ ?" (I forget the names mentioned.) "Yes, they are all with me." A woman's voice now from another part of the room anxiously cried out, "Hare you seen my sister?" "Yes, I have seen her." "Tell her my love is great towards her and never will cease." "Yes, I will tell." Here 
the woman burst into tears, and the pakeha felt a strange swelling of the chest, which he could in no way account for. The spirit spoke again. "Give my large tame pig to the priest (the pakeha was disenchanted at once) and my double-gun." Here the brother interrupted, "Your gun is a manatunga, I shall keep it." He is also disenchanted, thought I, but I was mistaken. He believed, but wished to keep the gun his brother had carried so long. An idea now struck me that I could expose the imposture without showing palpable disbelief. "We cannot find your book," said I, "where have you concealed it?" The answer instantly came, "I concealed it between the tahuhu of my house and the thatch, straight over you as you go in at the door." Here the brother rushed out; all was silence till his return. In five minutes he came back with the book in his hand. I was beaten, but made another effort. "What have you written in that book?" said I. "A great many things." "Tell me some of them." "Which of them?" "Any of them." "You are seeking for some information, what do you want to know? I will tell you." Then suddenly, "Farewell, O tribe! farewell, my family, I go!" Here a general and impressive cry of "farewell" arose from every one in the house. "Farewell," again cried the spirit, from deep beneath the ground! "Farewell," again from high in air! "Farewell," once more came moaning through the distant darkness of the night. "Farewell!" I was for a moment stunned. The deception was perfect. There was a dead silence - at last. 
"A ventriloquist," said I; "or-or-perliaps the deril."

I was fagged and confused. It was past midnight; the company broke up, and I went to a house where a bed had been prepared for me. I wished to be quiet and alone; but it was fated there should be little quiet that night. I was just falling asleep, after having thought for some time on the extraordinary scenes I had witnessed, when I heard the report of a musket at some little distance, followed by the shouting of men and the screams of women. Out I rushed. I had a presentiment of some horrible catastrophe. Men were running by, hastily armed. I could get no information, so went with the stream. There was a bright flame beginning to spring up at a short distance, and every one appeared going in that direction. I was soon there. A house had been set on fire to make a light. Before another house, close at hand, a dense circle of human beings was formed. I pushed my way through, and then saw, by the bright light of the flaming house, a scene which is still fresh before me: there, in the verandah of the house, was an old greybearded man; he knelt upon one knee, and on the other he supported the dead body of the young girl who had said she would follow the spirit to spirit land. The delicate-looking body from the waist upwards was bare and bloody; the old man's right arm was under the neck, the lower part of his long grey beard was dabbled with blood, his left hand was twisting his matted hair; he did not weep, he houled, and the sound was that of a heathen despair, knowing 
no hope. The young girl had secretly procured a loaded musket, tied a loop for her foot to the trigger, placed the muzzle to her tender breast, and blown herself to shatters. And the old man was her father, and a tohunga. A calm low voice now spoke close beside me, "She has followed her rangatira," it said. I looked round, and saw the famous toliunga of the night.

Now, young ladies, I have promised not to frighten your little wits out with raw-head-and-bloody-bones stories, a sort of thing I detest, but which has been too much the fashion with folks who write of matters Maori. I have vowed not to draw a drop of blood except in a characteristic manner. But this story is tragedy, or I don't know what tragedy is, and the more tragic because, in every particular, literally true, and so if you cannot find some pity for the poor Maori girl who "followed her lord to spirit land," I shall make it my business not to fall in love with any of you any more for I won't say how long.

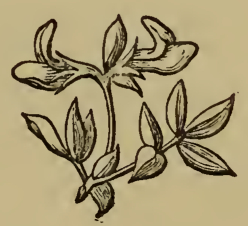




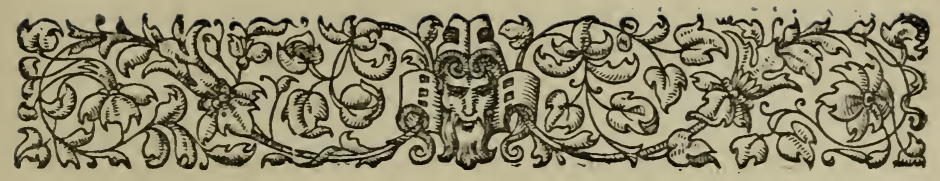

\section{Chapter XI.}

The local Tapu. - The Taniwha. - The battle on Motiti.The death of Tiki Whenua.-Reflections.-Brutus, Marcus Antonius, and Tiki Whenua.-Suicide.

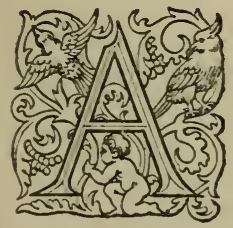

STORY-TELLER, like a poet or a pugilist, must be born, and not made, and I begin to fancy I have not been born under a story-telling planet, for by no effort that I can make can I hold on to the thread of my story, and I am conscious the whole affair is fast becoming one great parenthesis. If I could only get clear of this tapu I would "try back." I believe I ought to be just now completing the purchase of my estate. I am sure I hare been keeping house a long time before it is built, which is I believe clear against the rules, so I must get rid of this talk about the tapu the best way I can, after which I will start fair and try not to get before my story.

Besides these different forms of the tapu which I hare mentioned, there were endless others, but the temporary local tapus were the most tormenting to a pakeha, as well they might be, seeing that even a native could not steer clear of them always. A place not 
tapu yesterday might be most horribly tapu to-day, and the consequences of trespassing thereon proportionately troublesome. Thus, sailing along a coast or a river bank, the most inviting landing-place would be almost to a certainty the freehold property of the Taniwha, a terrific sea-monster, who would to a certainty, if his landed property was trespassed on, upset the canoe of the trespassers and devour them all the very next time they put to sea. The place was tapu, and let the weather be as bad as it might, it was better to keep to sea at all risks than to land there. Even pakeha, though in some cases invulnerable, could not escape the fangs of the terrible Taniwha. "Was not little Jackey-poto, the sailor, drowned by the Taniwha? He would go on shore, in spite of every warning, to get some water to mix with his waipiro, and was not his canoe found next day floating about with his paddle and two empty case bottles in it? - a sure sign that the Taniwha had lifted him out bodily. And was not the body of the said Jackey found some days after with the Taniwha's mark on it,- -one eye taken out?"

These Taniwha would, however, sometimes attach themselves to a chief or warrior, and in the shape of a huge sea monster, a bird, or a fish, gambol round his canoe, and by their motions give presage of good or evil fortune.

When the Ngati Kuri sailed on their last and fated expedition to the south, a huge Taniwha, attached to the famous warrior, Tiki Whenua, accompanied the expedition, playing about continually amongst the 
canoes, often coming close to the canoe of Tiki Whenua, so that the warrior could reach to pat him approvingly with his paddle, at which he seemed much pleased; and when they came in sight of the island of Tuhua, this Taniwha chief called up the legions of the deep! The sea was blackened by an army of monsters, who, with uncouth and awful floundering and wallowing, performed before the chief and his companions a hideous tu ngarahu, and then disappeared. The Ngati Kuri, elated, and accepting this as a presage of victory, landed on Tuhua, stormed the pa, and massacred its defenders. But they had mistaken the meaning of the monster review of the Taniwha. It was a leare-taking of his favourite warrior, for the Ngati Kuri were fated to die to a man on the next land they trod. A hundred and fifty men were they-the pick and prime of their tribe. All rangatira, all warriors of name, few in numbers, but desperately resolute, they thought it little to defeat the thousands of the south, and take the women and children as a prey! Having feasted and rejoiced at Tuhua, they sail for Motiti. This world was too small for them. They were impatient for battle. They thought to make the name of Kuri strike against the skies; but in the morning the sea is covered with war canoes. The thousands of the south are upon them! Ngati Awa, with many an allied band, mad for revenge, come on. Fight now, oh Ngati Kuri!-not for victory, no, nor for life. Think only now of utu!-for your time is come. That which you have dealt to many, you shall now 
receive. Fight!-fight! Your tribe shall be exterminated, but you must leave a name! Now came the tug of war on "bare Motiti." From early morning till the sun had well declined, that ruthless battle raged. Twice their own number had the Ngati Kuri slain; and then Tiki Whenua, still living, saw around him his dead and dying tribe. A handful of bleeding warriors still resisted-a last and momentary struggle. He thought of the utu; it was great. He thought of the ruined remnant of the tribe at home, and then he remembered-horrid thought! - that ere next day's setting sun, he and all the warriors of his tribe would be baked and eaten. (Tiki, my friend, thou art in trouble.) A cannon was close at hand-a nine-pound carronade. They had brought it in the canoes. Hurriedly he filled it half full of powder, seized a long firebrand, placed his breast to the cannon's mouth, fired with his own hand. Tiki Whenua, Good night!

Now I wonder if Brutus had had such a thing as a nine-pounder about him at Phillippi, whether he would have thought of using it in this way. I really don't think he would. I have never looked upon Brutus as anything of an original genius, but Tiki Whenua most certainly was. I don't think there is another instance of a man blowing himself from a gun-of course there are many examples of people blowing others from cannon, but that is quite a different thing - any blockhead can do that. But the exit of Tiki Whenua has a smack of originality about it which I like, and so I have mentioned it here. 
But all this is digression on digression; however, I suppose the reader is getting used to it, and I cannot help it; besides, I wanted to show them how poor Tiki "took arms against a sea of troubles," and for the want of a "bare bodkin" made shift with a carronade. I shall never cease to lament those nice lads who met with that little accident (poor fellows!) on Motiti. A fine, strapping, stalwart set of fellows, who believed in force. We don't see many such men now-a-days; the present generation of Maori are a sturted, tobacco-smoking, grog-drinking, psalm-singing, special-pleading, shilling-hunting set of wretches ; not above one in a dozen of them would know how to cut up a man secundem artem. Pshaw! I am ashamed of them.

I am getting tired of this tapu, so will give only one or two more instances of the local temporary tapu. In the autumn, when the great crop of kumera was gathered, all the paths leading to the village and cultivated lands were made tapu, and any one coming along them would have notice of this by finding a rope stretched across the road about breast-high; when he saw this, his business must be very urgent indeed or he would go back, and it would have been taken as a very serious affront indeed, even in a near relation, supposing his ordinary residence was not in the village, to disregard the hint given by the rope, -that for the present there was "no thoroughfare." Now, the reason of this blockade of the roads was this. The report of an unusually fine crop of kumera had often cost its cultivators and the whole 
tribe their lives. The news would spread about that $\mathrm{Ngati}$ so-and-so, living at so-and-so, had housed so many thousands of baskets of kumera. Exaggeration would multiply the truth by ten, the fertile land would be coveted, and very probably its owners, or rather its holder's, would have to fight both for it and their lives before the year was out. For this reason strangers were not welcome at the Maori harvest home. The kumera were dug hurriedly by the whole strength of the working hands, thrown in scattered heaps, and concealed from any casual observation by strangers by being covered over with the leaves of the plants, and when all were dug then all hands set to work, at night, to fill the baskets and carry off the crop to the storehouse or rua, and every effort was made to get all stored and out of sight before daylight, lest any one should be able to form any idea of the extent of the crop. When the digging of one field was completed another would be done in the same manner, and so on till the whole crop was housed in this stealthy manner. I have been at several of these midnight labours, and have admired the immense amount of work one family would do in a single night, working as it were for life and death. In consequence of this mode of proceeding, even the families inhabiting the same village did not know what sort of a crop their neighbours had, and if a question was asked (to do which was thought impertinent and very improper), the invariable answer was, "Nothing at all; barely got back the seed; hardly that; we shall be starved; we 
shall have to eat fern root this year," \&c. The last time I observed this custom was about twenty-seven years ago, and even then it was nearly discontinued and no longer general.

Talking of bygone habits and customs of the natives, I remember I have mentioned two cases of suicide. I shall, therefore, now take occasion to state that no more marked alteration in the habits of the natives has taken place than in the great decrease of cases of suicide. In the first years of my residence in the country, it was of almost daily occurrence. When a man died, it was almost a matter of course that his wife, or wives, hung themselves. When the wife died, the man very commonly shot himself. I hare known young men, often on the most trifling affront or rexation, shoot themselves; and I was acquainted with a man who, haring been for two days plagued with the toothache, cut his throat with a very blunt razor, without a handle, as a radical cure, which it certainly was. I do not believe that one case of suicide occurs now, for twenty when I first came into the country. Indeed, the last case I have heard of in a populous district, occurred several years ago. It was rather a remarkable one. A native owed another a few shillings; the creditor kept continually asking for it; but the debtor, somehow or other, never could raise the cash. At last, being out of patience, and not knowing anything of the Insolvent Court, he loaded his gun, went to the creditor's house, and called him out. Out came the creditor and his wife. The debtor then placed the gun to his own breast, 
and saying, "Here is your payment," pulled the trigger with his foot, and fell dead before them. I think the reason suicide has become so comparatively unfrequent is, that the minds of the natives are now filled and agitated by a flood of new ideas, new wants and ambitions, which they knew not formerly, and which prevents them, from one single loss or disappointment, feeling as if there was nothing more to live for.

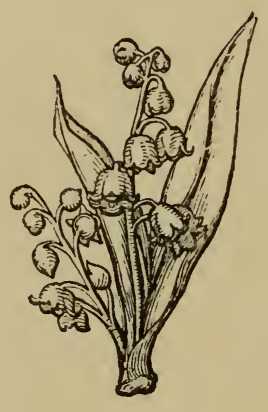




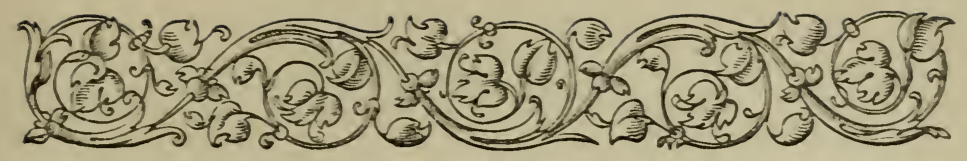

\section{Chapter XiI.}

The Tapa.-Instances of._The storming of Mokoia._Pomare.Hongi Ika._Tareha.-Honour amongst thieves.

HERE was a kind of rariation on the
topu, called tapa, of this nature. For intents and purposes, except, indeed, the owner of the axe was able to break his " head," in which case, I have reason to believe, the tapa would fall to the ground. It was, howerer, in a certain degree necessary to hare some legal reason, or excuse, for making the tapa; but to gire some idea of what constituted the circumstances under which a man could fairly tapa anything, I must needs quote a case in point.

When the Ngapuhi attacked the tribe of Ngati Wakawe, at Rotorua, the Ngati Wakarre retired to the island of Mokoia in the lake of Rotorua, which they fortified, thinking that, as the Ngapuhi canoes could not come nearer than Kaituna on the east coast, about thirty miles distant, they in their island position would be safe. But in this they were fatally deceived, for the Ngapuhi dragged a whole fleet of war canoes orer land. When, however, the 
advanced division of the Ngapuhi arrived at Rotorua, and encamped on the shore of the lake, Ngati Wakawe were not aware that the canoes of the enemy were coming, so every morning they manned their large canoes, and leaving the island fort, would come dashing along the shore, deriding the Ngapuhi, and crying, "Ma wai koe e kawe mai ki Rangitiki?""Who shall bring you, or how shall you arrive, at Rangitiki?" Rangitiki was the name of one of their hill forts. The canoes were fine large ornamented totara canoes, very valuable, capable of carrying from fifty to seventy men each, and much coveted by the Ngapuhi. The Ngapuhi, of course, considered all these canoes as their own already, but the different chiefs and leaders, anxious to secure one or more of these fine canoes for themselves and people, and not knowing who might be the first to lay hands on them in the confusion of the storming of Mokoia, which would take place when their own canoes arrived, each tapa'd one or more for himself, or, as the native expression is, to himself. Up jumped Pomare, and standing on the lake shore, in front of the encampment of the division of which he was leader, he shouts, pointing at the same time to a particular canoe at the time carrying about sixty men, "That canoe is my back-bone." Then Tareha, in bulk like a sea-elephant, and sinking to the ankles in the shore of the lake, with a hoarse, croaking voice roars out, "That canoe! my skull shall be the baler to bale it out." This was a horribly strong tapa. Then the soft voice of the famous Hongi Ika, surnamed "The eater of men," of 
Hongi kai tangata, was heard, "Those two canoes are my two thighs." And so the whole flotilla was appropriated by the different chiefs. Now it followed from this that in the storming and plunder of Mokoia, when a warrior clapped his hand on a canoe and shouted, "This canoe is mine," the seizure would not stand good if it was one of the canoes which were tapa-tapa, for it would be a frightful insult to Pomare to claim to be the owner of his "back-bone," or to Tareha to go on board a canoe which had been made sacred by the bare supposition that his "skull" should be a vessel to bale it with. Of course the first man laying his hand on any other canoe, and claiming it, secured it for himself and tribe, always provided that the number of men there present representing his tribe or hapu were sufficient to back his claim, and render it dangerous to dispossess him. I have seen men shamefully robbed, for want of sufficient support, of their honest lawful gains, after all the trouble and risk they had gone to in killing the owners of their plunder. But dishonest people are to be found almost everywhere, and I will say this, that my friends the Maoris seldom act against law, and always try to be able to say what they do is "correct" (tika).

This tapu is a bore, even to write about, and I fear. the reader is beginning to think it a bore to read about. It began long before the time of Moses, and I think that steam navigation will be the death of it; but lest it should kill my reader, I will have done with it for the present, and "try back," for I hare left my story behind completely. 


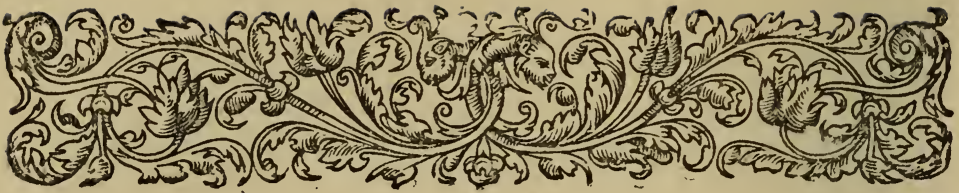

\section{Chapter XIII.}

"My Rangatira."-The respective duties of the Pakeha and his Rangatira.-Public opinion.-A "Pakeha Kino."-Description of my Rangatira.-His exploits and misadventures.-His moral principles.-Decline in the numbers of the natives.Proofs of former large population.-Ancient forts.-Causes of decrease.

(n) payment (1) was made on the ground, and imme(3.5) (1) (4) diately divided and subdivided amongst अ who, according to their own representations formerly made to me, were the sole and only owners of the land, received for their share about the value of one shilling, and moreover, as I also observed, did not appear at all disappointed.

One old rangatira, before whom a considerable portion of the payment had been laid as his share of the spoil, gave it a slight shove with his foot, expressive of refusal, and said, "I will not accept any of the payment, I will have the pakeha." I saw some of the magnates present seemed greatly disappointed at this, for I dare say they had expected to have the pakeha as well as the payment. But the old gentleman had regularly checkmated them by refusing to accept any 
payment, and being also a person of great respectability, i.e., a good fighting man, with twenty more at his back, he was allowed to have his way, and thereby, in the opinion of all the natives present, making a far better thing of the land sale than any of them, though he had received no part of the payment.

I consequently was therefore a part, and by no means an inconsiderable one, of the payment for my own land; but though now part and parcel of the property of the old rangatira aforementioned, a good deal of liberty was allowed me. The fact of my having become his pakeha made our respective relations and duties to each other about as follows:-

Firstly.-At all times, places, and companies my owner had the right to call me "his pakeha."

Secondly.-He had the general privilege of "potluck" whenever he chose to honour my establishment with a visit; said pot-luck to be tumbled out to him on the ground before the house, he being far too great a man to eat out of plates or dishes, or any degenerate invention of that nature; as, if he did, they would all become tapu, and of no use to any one but himself, nor indeed to himself either, as he did not see the use of them.

Thirdly.-It was well understood that to avoid the unpleasant appearance of paying "black mail," and to keep up general kindly relations, my owner should from time to time make me small presents, and that in return I should make him presents of five or six times the value: all this to be done as if arising from mutual love and kindness, and not the 
slightest allusion to be ever made to the relative value of the gifts on either side (an important article).

Fourthly.-It was to be a sine quâ non that I must purchase everything the chief or his family had to sell, whether I wanted them or not, and give the highest market price, or rather more. (Another very important article.)

Fifthly.-The chief's own particular pipe never to be allowed to become extinguished for want of the needful supply of tobacco.

Sixthly.-All desirable jobs of work, and all advantages of all kinds, to be offered first to the family of my rangatira before letting any one else have them; payment for same to be about 25 per cent. more than to any one else, exclusive of a douceur to the chief himself because he did not work.

In return for these duties and customs, well and truly performed on my part, the chief was understood to-

Firstly.-Stick up for me in a general way, and not let me be bullied or imposed upon by any one but himself, as far as he was able to prevent it.

Secondly.-In case of my being plundered or maltreated by any powerful marauder, it was the duty of my chief to come in hot haste with all his family, armed to the teeth, to my rescue, after all was over, and when it was too late to be of any service. $\mathrm{He}$ was also bound on such occasions to make a great noise, dance the war dance, and fire muskets, (I finding the powder, ) and to declare loudly what he would 
have done had he only been in time. I, of course, on such occasions, for my own dignity, and in consideration of the spirited conduct of my friends, was bound to order two or three fat pigs to be killed, and lots of potatoes to be served out to the "army," who were always expected to be starving, as a general rule. A distribution of tobacco, in the way of largess, was also a necessity of the case.

Thirdly.-In case of my losing anything of consequence by theft-a thing which, as a veracious pakeha, I am bound to say, seldom happened; the natives in those days being, as I have already mentioned, a very law-observing people, (the law of muru, had, indeed, little occasion to steal, the abovenamed law answering their purposes in a general way much better, and helping them pretty certainly to any little matter they coreted; yet, as there are exceptions to all rules, theft would sometimes be committed; and then, as I was saying, it became the bounden duty of my rangatira to get the stolen article back if he was able, and keep it for himself for his trouble, unless I gave him something of more value in lieu thereof.

Under the above regulations things went on pleasantly enough, the chief being restrained, by public opinion and the danger of the pakeha running away from pushing his prerogative to the utmost limit; and the pakeha, on the other hand, making the commonalty pay for the indirect taxation he was subjected to; so that in general, after ten or fifteen years' residence, he would not be much poorer than 
when he arrived, unless, indeed, some unlucky accident happened, such as pakehas were liable to sometimes in the good old times.

Mentioning "public opinion" as a restraint on the chiefs' acquisitiveness, I must explain that a chief possessing a pakeha was much envied by his neighbours, who, in consequence, took every opportunity of scandalizing him, and blaming him for any rough plucking process he might submit the said pakeha to; and should he, by any awkward handling of this sort, cause the pakeha at last to run for it, the chief would never hear the end of it from his own family and connections, pakehas being, in those glorious old times, considered to be geese who laid golden eggs, and it would be held to be the very extreme of foolishness and bad policy either to kill them, or, by too rough handling, to cause them to fly away.

On the other hand, should the pakeha fail in a culpable manner in the performance of his duties, though he would not, as a rule, be subjected to any stated punishment, he would soon begin to find a most unaccountable train of accidents and all sorts of unpleasant occurrences happening, enough, in the aggregate, to drive Job himself out of his wits; and, moreover, he would get a bad name, which, though he removed, would follow him from one end of the island to the other, and effectually prevent him having the slightest chance of doing any good,-that is, holding his own in the country, as the natives, wherever he went, would consider him a person out of whom the most was to be made at once, as he was not 
to be depended on as a source of permanent revenue. I have known several industrious, active, and sober pakeha who never could do any good, and whose life, for a long series of years, was a mere train of mishaps, till at last they were reduced to extreme poverty, merely from having, in their first dealings with the natives, got a bad name, in consequence of not having been able to understand clearly the beauty of the set of regulations I have just mentioned, and from an inability to make them work smoothly. The bad name I have mentioned was short and expressive; wherever they went, there would be sure to be some one who would introduce them to their new acquaintances as "a pakeha pakeke,"-a hard pakeha; "a pakeha taehae," - a miser; or, to sum up all, "a pakeha kino."

The chief who claimed me was a good specimen of the Maori rangatira. He was a very old man, and had fought the French when Marion, the French circumnavigator, was killed. He had killed a Frenchman himself, and carried his thighs and legs many miles as a bonne bouche for his friends at home at the pa. This old gentleman was not head of his tribe. He was a man of good family, related to several high chiefs. He was head of a strong family, or hapu, which mustered a considerable number of fighting men, all his near relations. He had been himself a most celebrated fighting man, and a war chief; and was altogether a highly respectable person, and of great weight in the councils of the tribe. I may say I was fortunate in having been appropriated 
by this old patrician. He gave me very little trouble; did not press his rights and privileges too forcibly on my notice, and in fact behaved in all respects towards $m e$ in so liberal and friendly a manner, that before long I began to have a very sincere regard for him, and he to take a sort of paternal interest in me, which was both gratifying to observe, and also extremely comical sometimes, when he, out of real anxiety to see me a perfectly accomplished rangatira, would lecture on good manners, etiquette, and the use of the spear. He was, indeed, a model of a rangatira, and well worth being described. He was a little man, with a high massive head, and remarkably high square forehead, on which the tattooer had exhausted his art. Though, as I have said, of a great age, he was still nimble and active. He had evidently been one of those tough, active men, who, though small in stature, are a match for any one. There was in my old friend's eyes a sort of dull fiery appearance, which, when anything excited him, or when he recounted some of those numerous battles, onslaughts, massacres, or stormings in which all the active part of his life had been spent, actually seemed to blaze up and give forth real fire. His breast was covered with spearwounds, and he also had two very severe spearwounds on his head; but he boasted that no single man had ever been able to touch him with the point of a spear. It was in grand mêlées, where he would have sometimes six or eight antagonists, that he had received these wounds. He was a great 
general, and I have heard him criticize closely the order and conduct of every battle of consequence which had been fought for fifty years before my arrival in the country. On these occasions the old "martialist" would draw on the sand the plan of the battle he was criticizing and describing; and in the course of time I began to perceire that, before the introduction of the musket, the art of war had been brought to great perfection by the natives: and that, when large numbers were engaged in a pitched battle, the order of battle resembled, in a most striking manner, some of the most approved orders of battle of the ancients. Since the introduction of firearms the natives have entirely altered their tactics, and adopted a system better adapted to the new weapon and the nature of the country.

My old friend had a great hatred for the musket. He said that in battles fought with the musket there were never so many men killed as when, in his young days, men fought hand to hand with the spear; when a good warrior would kill six, eight, ten, or even twenty men in a single fight; for when once the enemy broke and commenced to run, the combatants being so close together, a fast runner would knock a dozen on the head in a short time; and the great aim of these fast-running warriors, of whom my old friend had been one, was to chase straight on and never stop, only striking one blow at one man, so as to cripple him, so that those behind should be sure to overtake and finish him. It was not uncommon for 
one man, strong and swift of foot, when the enemy were fairly routed, to stab with a light spear ten or a dozen men in such a way as to ensure their being overtaken and killed. On one occasion of this kind my old tutor had the misfortune to stab a running man in the back. He did it, of course, scientifically, so as to stop his running, and as he passed him by he perceived it was his wife's brother. He was finished immediately by the men close behind. I should have said the man was a brother of one of my friend's four wives, which being the case, I dare say he had a sufficient number of brothers-in-law to afford to kill one now and then. A worse mishap, however, occurred to him on another occasion. He was returning from a successful expedition from the south (in the course of which, by-the-bye, he and his men killed and cooked several men of the enemy in Shortland Crescent, and forced three others to jump over a cliff, which is, I think, now called Soldier's Point), when off the Mahurangi a smoke was seen rising from amongst the trees near the beach. They at once concluded that it came from the fires of people belonging to that part of the country, and who they considered as game. They therefore waited till night, concealing their canoes behind some rocks, and when it became dark landed; they then divided into two parties, took the supposed enemy completely by surprise, attacked, rushing upon them from two opposite directions at once. My rangatira, dashing furiously among them, and, as I can well suppose, those eyes of his flashing fire, had the happiness of once again 
killing the first man, and being authorized to shout, "Ki au te mataila!" A few more blows, the parties recognize each other: they are friends!-men of the same tribe! Who is the last mataika slain by this famous warrior? Quick, bring a flaming brand; here he lies dead! Ha! It is his father!

Now an ancient knight of romance, under similar awkward circumstances, would probably have retired from public life, sought out some forest cave, where he would have hung up his armour, let his beard grow, flogged himself twice a day "regular," and lived on "pulse," which, I suppose, means pea-soup, for the rest of his life. But my old rangatira and his companions had not a morsel of that sort of romance about them. The killing of my friend's father was looked upon as a very clever exploit in itself, though a very unlucky one. So after having scolded one another for some time, one party telling the other they were served right for not keeping a better look out, and the other answering that they should have been sure who they were going to attack before making the onset, they all held a tangi or lamentation for the old warrior who had just received his mittimus; and then lilling a prisoner, who they had brought in the canoes for fresh provisions, they had a good feast; after which they returned all together to their orn country, taking the body of their lamented relative along with them. This happened many years before I came to the country, and when my rangatira was one of the most famous fighting men in his tribe.

This Maori rangatira, who I am describing, had 
passed his whole life, with but little intermission, in a scene of battle, murder, and bloodthirsty atrocities of the most terrific description, mixed with actions of the most heroic courage, self-sacrifice, and chivalric daring, as leaves one perfectly astounded to find them the deeds of one and the same people-one day doing acts which had they been performed in ancient Greece would have immortalized the actors, and the next committing barbarities too horrible for relation, and almost incredible.

The effect of a life of this kind was observable, plainly enough, in my friend. He was utterly devoid of what weak mortals call " compassion." He seemed to have no more feeling for the pain, tortures, or death of others than a stone. Should one of his family be dying or wounded, he merely felt it as the loss of one fighting man. As for the death of a woman or any non-combatant, he did not feel it at all, though the person might have suffered horrid tortures; indeed I have seen him scolding severely a fine young man, his near relative, when actually expiring, for being such a fool as to blow himself up by accident, and deprive his family of a fighting man. The last words the dying man heard were these:-_ It serves you right. There you are, looking very like a burnt stick! It serves you right-a burnt stick! Serves you right!" It really was vexatious, A fine stout young fellow to be wasted in that way. As for fear, I saw one or two instances to prove he knew very little about it; and, indeed, to be killed in battle, seemed to him a natural death, and he was always 
grumbling that the young men thought of nothing but trading: and whenerer he proposed to them to take him where he might have a final battle (he riri wakamutunga), where he might escape dying of old age, they always kept saying, "Wait till we get more muskets," or "more gunpowder," or more something or another, "as if men could not be killed without muskets!" He was not cruel either; he was only unfeeling. He had been guilty, it is true, in his time, of what we would call terrific atrocities to his prisoners, which he calmly and calculatingly perpetrated as utu or retaliation for similar barbarities committed by them or their tribe. And here I must retract the word guilty, which I see I have written inadvertently, for according to the morals and principles of the people of whom he was one, and of the time to which he belonged, and the training he had received, so far from being guilty, he did a praisemorthy, glorious, and public-spirited action when he opened the jugular vein of a bound captive and sucked huge draughts of his blood. To say the truth he was a very nice old man, and I liked him very much. It would not, however, be advisable to put him in a passion; not much good would be likely to arise from it, as indeed I could show by one or two very striking instances which came under my notice, though to say the truth he was not easily put out of temper. He had one great moral rule,-it was indeed his rule of life,--he held that erery man had a right to do everything and anything he chose, provided he was able and willing to stand the conse- 
quences, though he thought some men fools for trying to do things which they could not carry out pleasantly, and which ended in getting them baked. I once hinted to him that, should every one reduce these principles to practice, he himself might find it awkward, particularly as he had so many mortal enemies. To which he replied, with a look which seemed to pity my ignorance, that every one did practise this rule to the best of their abilities, but that some were not so able as others; and that as for his enemies, he should take care they never surprised him; a surprise being, indeed, the only thing he seemed to have any fear at all of. In truth he had occasion to look out sharp; he never was known to sleep more than three or four nights in the same place, and often, when there were ill omens, he would not sleep in a house at all, or two nights following in one place, for a month together, and I never saw him without both spear and tomahawk, and ready to defend himself at a second's notice, a state of preparation perfectly necessary, for though in his own country and surrounded by his tribe, his death would have been such a triumph for hundreds, not of distant enemies, but of people within a day's journey, that none could tell at what moment some stout young fellow in search of utu and a "ingoa toa" (a warlike reputation) might rush upon him, determined to have his head or leave his ornn. The old buck himself had, indeed, performed several exploits of this nature, the last of which occurred just at the time I came into the country, but before I had the 
advantage of his acquaintance. His tribe were at war with some people at the distance of about a day's journey. One of their villages was on the border of a dense forest. My rangatira, then a very old man, started off alone, and without saying a word to any one, took his way through the forest which extended the whole way between his village and the enemy, crept like a lizard into the enemy's village, and then, shouting his war cry, dashed amongst a number of people he saw sitting together on the ground, and who little expected such a salute. In a minute he had run three men and one woman through the body, received five dangerous spear-wounds himself, and escaped to the forest, and finally got safe home to his own country and people. Truly my old rangatira was a man of a thousand,-a model rangatira. This exploit, if possible, added to his reputation, and every one said his mana would never decline. The enemy had been panic-stricken, thinking a whole tribe were upon them, and fled like a flock of sheep, except the three men who were killed. They all attacked my old chief at once, and were all disposed of in less than a minute, after, as I have said, giving him five desperate wounds. The woman was just "stuck," as a matter of course, as she came in his way.

The natives are unanimous in affirming that they were much more numerous in former times than they are now, and I am convinced that such was the case, for the following reasons. The old hill forts are many of them so large that an amount of labour 
must hare been expended in trenching, terracing, and fencing them, and all without iron tools, which increased the difficulty a hundred-fold, which must have required a rastly greater population to accomplish than can be now found in the surrounding districts. These forts were also of such an extent that, taking into consideration the srstem of attack and defence used necessarily in those times, they would have been utterly untenable unless held by at least ten times the number of men the whole surrounding districts, for two or three days' journey, can produce; and yet, when we remember that in those times of constant war, being the two centuries preceding the arrival of the Europeans, the natires almays, as a rule, slept in these hill forts with closed gates, bridges over trenches remored, and ladders of terraces drarn up, we must come to the conclusion that the inhabitants of the fort, though so numerous, were merely the population of the country in the close vicinity. Now from the top of one of these pointed, trenched, and terraced hills, I have counted twenty others, all of equally large dimensions, and all within a distance, in erery direction, of fifteen to twenty miles; and natire tradition affirms that each of these hills was the stronghold of a separate hapu or clan, bearing its distinctire name. There is also the most unmistakeable evidence that rast tracts of country; which hare lain wild time out of mind, were once fully cultivated. The ditches for draining the land are still traceable, and la:"ge pits are to be seen in hundreds, on the tops of the dry hills, all over the 
northern part of the North Island, in which the kumera were once stored; and these pits are, in the greatest number, found in the centre of great open tracts of uncultirated country, where a rat in the present day would hardly find subsistence. The old drains, and the peculiar growth of the timber, mark clearly the extent of these ancient cultivations. It is also very observable that large tracts of very inferior. land have been in cultivation, which would lead to the inference that either the population was pretty nearly proportioned to the extent of available land, or that the tracts of inferior land were cultivated merely because they were not too far remored from the fort; for the shape of the hill, and its capability of defence and facility of fortification, was of more consequence than the fertility of the surrounding country. These kumera pits, being dug generally in the stiff clay on the hill tops, have, in most cases, retained their shape perfectly, and many seem as fresh and new as if they had been dug but a few years. They are oblong in shape, with the sides regularly sloped. Many collections of these provision stores have outlived Maori tradition, and the natives can only conjecture who they belonged to. Out of the centre of one of them which I have seen, there is now growing a kauri tree one hundred and twenty feet high, and out of another a large totara. The outline of these pits is as perfect as the day they were dug, and the sides have not fallen in in the slightest degree, from which perhaps they have been preserved by the absence of frost, as well as by a beautiful 
coating of moss, by which they are everywhere covered. The pit in which the kauri grew, had been partially filled up by the scaling off of the bark of the tree, which falling off in patches, as it is constantly doing, had raised a mound of decaying bark round the root of the tree.

Another evidence of a very large number of people having once inhabited these hill forts is the number of houses they contained. Every native house, it appears, in former times as in the present, had a fireplace composed of four flat stones or flags sunk on their edges into the ground, so as to form an oblong case or trunk, in which at night a fire to heat the house was made. Now, in two of the largest hill forts I have examined, though for ages no vestige of a house had been seen, there remained the fire-places - the four stones projecting like an oblong box slightly over the ground-and from their position and number denoting clearly that, large as the circumference of the huge volcanic hill was which formed the fortress, the number of families inhabiting it necessitated the strictest economy of room. The houses had been arranged in streets, or double rows, with a path between them, except in places where there had been only room on a terrace for a single row. The distances between the fire-places proved that the houses in the rows must have been as close together as it was possible to build them, and every spot, from the foot to the hill top, not required and specially planned for defensive purposes, had been built on in this regular manner. Even the small 
flat top, sixty yards long by forty wide,- the citadel, -on which the greatest care and labour had been bestowed to render it difficult of access, had been as full of houses as it could hold, learing a small space all round the precipitous bank for the defenders to stand on.

These little fire-places, and the scarped and terraced conical hills, are the only marks the Maori of ancient times have left of their existence. And I have reasons for believing that this country has been inhabited from a more remote period by far than is generally supposed. These reasons I found upon the dialect of the Maori language spoken by the Maori of New Zealand, as well as on many other circumstances.

We may easily imagine that a hill of this kind, covered from bottom to top with houses thatched and built of reeds, rushes, and raupo, would be a mere mass of combustible matter, and such indeed was the case. When an enemy attacked one of these places a common practice was to shower red-hot stones from slings into the place, which, sinking into the dry thatch of the houses, would cause a general conflagration. Should this once occur the place was sure to be taken, and this mode of attack was much feared; all hands not engaged at the outer defences, and all women and non-combatants, were employed guarding against this danger, and pouring water out of calabashes on every smoke that appeared. The natives also practised both mining and escalade in attacking a hill fort.

The natives attribute their decrease in numbers, 
before the arrival of the Europeans, to war and sickness, disease possibly arising from the destruction of food and the forced neglect of cultivation caused by the constant and furious wars which devastated the country for a long period before the arrival of the Europeans, in such a manner that the natives at last believed that a constant state of warfare was the natural condition of life, and their sentiments, feelings, and maxims became gradually formed on this belief. Nothing was so valuable or respectable as strength and courage, and to acquire property by war and plunder was more honourable and also more desirable than by labour. Cannibalism was glorious. The island was a pandemonium.

A rugged wight, the worst of brutes, was man;

On his own wretched kind he ruthless prey'd.

The strongest then the weakest overran,

In every country mighty robbers sway'd,

And guile and ruffian force was all their trade.

Since the arrival of the Europeans the decrease of the natives has also been rapid. In that part of the country where I have had means of accurate observation, they have decreased in number since my arrival rather more than one-third. I have, however, observed that this decrease has for the last ten years been very considerably checked, though I do not believe this improvement is general through the country, or even permanent where I have observed it.

The first grand cause of the decrease of the natives since the arrival of the Europeans is the musket. The nature of the ancient Maori weapons prompted 
them to seek out vantage ground, and to take up positions on precipitous hill tops, and make those high, dry, airy situations their regular fixed residences. Their ordinary course of life, when not engaged in warfare, was regular, and not necessarily unhealthy. Their labour, though constant in one shape or other, and compelled by necessity, was not too heary. In the morning, but not early, they descended from the hill pa to the cultivations in the low ground; they went in a body, armed like men going to battle, the spear or club in one hand, and the agricultural instrument in the other. The women followed. Long before night (it was counted unlucky to work till dark) they returned to the hill with a reversed order, the women now, and slaves, and lads, bearing fuel and water for the night, in front; they also bore probably heavy loads of kumera or other provisions. In the time of year when the crops did not call for their attention, when they were planted and growing, then the whole tribe would remove to some fortified hill, at the side of some river, or on the coast, where they would pass months fishing, making nets, clubs, spears, and implements of various descriptions; the women, in all spare time, making mats for clothing, or baskets to carry the crop of kumera in, when fit to dig. There was very little idleness; and to be called "lazy" was a great reproach. It is to be observed that for several months the crops could be left thus unguarded with perfect safety, for the Maori, as a general rule, never destroyed groming crops or attacked their owners in a regular manner 
until the crops were nearly at full perfection, so that they might afford subsistence to the invaders, and consequently the end of the summer all over the country was a time of universal preparation for battle, either offensive or defensive, the crops then being near maturity.

Now when the natives became generally armed with the musket they at once abandoned the hills, and, to save themselves the great labour and inconvenience occasioned by the necessity of continually carrying provisions, fuel, and water to these precipitous hill-castles-which would be also, as a matter of necessity, at some inconvenient distance from at least some part of the extensive cultivations-descended to the low lands, and there, in the centre of the cultivations, erected a new kind of fortification adapted to the capabilities of the new weapon. This was their destruction. There in mere swamps they built their oven-like houses, where the water even in summer sprung with the pressure of the foot, and where in winter the houses were often completely flooded. There, lying on the spongy soil, on beds of rushes which rotted under them-in little, low dens of houses, or kennels, heated like ovens at night and dripping with damp in the day-full of noxious exhalations from the damp soil, and impossible to ventilatethey were cut off by disease in a manner absolutely frightful. No advice would they take; they could not see the enemy which killed them, and therefore could not believe the Europeans who pointed out the cause of their destruction. 
This change of residence was universal and everywhere followed by the same consequences, more or less marked; the strongest men were cut off and but few children were reared. And even now, after the dreadful experience they have had, and all the continual remonstrances of their pakeha friends, they take but rery little more precaution in choosing sites for their houses than at first; and when a native village or a native house happens to be in a dry, healthy situation, it is often more the effect of accident than design.

Twenty years ago a hapu, in number just forty persons, removed their kainga from a dry, healthy position, to the edge of a raupo swamp. I happened to be at the place a short time after the removal, and with me there was a medical gentleman who was travelling through the country. In creeping into one of the houses (the chief's) through the low door, I was obliged to put both my hands to the ground; they both sunk into the swampy soil, making holes which immediately filled with water. The chief and his family were lying on the ground on rushes, and a fire was burning, which made the little den, not in the highest place more than five feet high, feel like an oven. I called the attention of my friend to the state of this place called a "house." He merely said, "men cannot live here." Eight years from that day the whole hapu were extinct; but, as I remember, two persons were shot for bewitching them and causing their deaths.

Many other causes combined at the same time to 
work the destruction of the natives. Next to the change of residence from the high and healthy hill forts to the low grounds, was the hardship, overlabour, exposure, and half-starvation, to which they submitted themselves-firstly, to procure these very muskets which enabled them to make the fatal change of residence, and afterwards to procure the highly and justly valued iron implements of the Europeans. When we reflect that a ton of cleaned flax was the price paid for two muskets, and at an earlier date for one musket, we can see at once the dreadful exertion necessary to obtain it. But supposing a man to get a musket for half a ton of flax, another half ton would be required for ammunition; and in consequence, as every man in a native hapu, of say a hundred men, was absolutely forced on pain of death to procure a musket and ammunition at any cost, and at the earliest possible moment (for if they did not procure them extermination was their doom by the hands of those of their countrymen who had), the effect was that this small hapu, or clan, had to manufacture, spurred by the penalty of death, in the shortest possible time, one hundred tons of flax, scraped by hand with a shell, bit by bit, morsel by morsel, half-quarter of an ounce at a time. Now as the natives, when undisturbed and labouring regularly at their cultivations, were never far removed from necessity or scarcity of food, we may easily imagine the distress and hardship caused by this enormous imposition of extra labour. They were obliged to neglect their crops in a very serious 
degree, and for many months in the year were in a half-starving condition, working hard all the time in the flax swamps. The insufficient food, over exertion, and unwholesome locality, killed them fast. As for the young children, they almost all died; and this state of things continued for many years: for it was long after being supplied with arms and ammunition before the natives could purchase, by similar exertion, the various agricultural implements, and other iron tools so necessary to them; and it must always be remembered, if we wish to understand the difficulties and over-labour the natives were subjected to, that while undergoing this immense extra toil, they were at the same time obliged to maintain themselves by cultivating the ground with sharpened sticks, not being able to afford to purchase iron implements in any useful quantity, till first the great, pressing, paramount want of muskets and gunpowder had been supplied. Thus continual excitement, over-work, and insufficient food, exposure, and unhealthy places of residence, together with a general breaking up of old habits of life, thinned their numbers. European diseases also assisted, but not to any very serious degree; till in the part of the country in which, as I have before stated, I have had means to observe with exactitude, the natives have decreased in numbers over one-third since I first saw them. That this rapid decrease has been checked in some districts, I am sure, and the cause is not a mystery. The influx of Europeans has caused a competition in trading, which enables them to get the 
highest value for the produce of their labour, and at the same time opened to them a hundred new lines of industry, and also afforded them other opportunities of becoming possessed of property. They have not at all improved these advantages as they might have done; but are, nevertheless, as it were in spite of themselves, on the whole, richer - i.e., better clothed, fed, and in some degree lodged, than in past years; and I see the plough now running where I once saw the rude pointed stick poking the ground. I do not, however, believe that this improvement exists in more than one or two districts in any remarkable degree, nor do I think it will be permanent where it does exist, insomuch as I have said that the improvement is not the result of providence, economy, or industry, but of a train of temporary circumstances favourable to the natives; but which, if unimproved, as they most probably will be, will end in no permanent good result. 


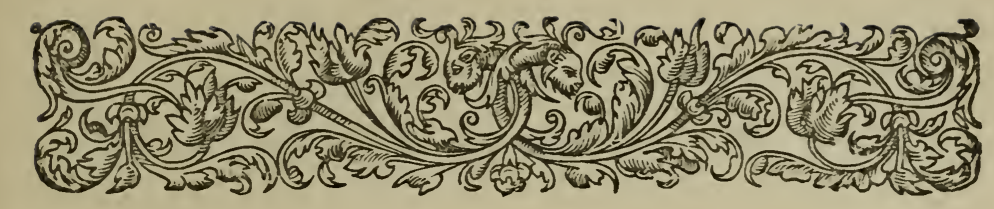

\section{Chapter XIV.}

Trading in the old times.-The native difficulty.-Virtue its own reward.-Rule Britannia.-Death of my chief.-His dying speech.-Rescue.-How the world goes round.

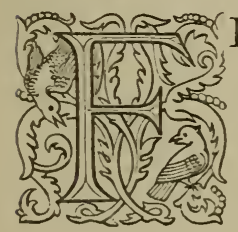

RON the years 1822 to 1826 , the vessels trading for flax had, when' at anchor, boarding nettings up to the tops. All the crew were armed, and, as a standing rule, not more than five natives, on any pretence, allowed on board at one time. Trading for flax in those days was to be undertaken by a man who had his wits about him; and an old flax trader of those days, with his 150 ton schooner "out of Sydney," cruising all round the coast of New Zealand, picking up his five tons at one port, ten at another, twenty at another, and so on, had questions, commercial, diplomatic, and military, to solve every day, that would drive all the "native department," with the minister at their head, clean out of their senses. Talk to me of the "native difficulty"pooh! I think it was in 1822 that an old friend of mine bought, at Kawhia, a woman who was just going to be baked. He gave a cartridge-box full of 
cartridges for her, which was a great deal more than she was really worth; but humanity does not stick at trifles. He took her back to her friends at Taranaki, from whence she had been taken, and her friends there gave him at once two tons of flax and eighteen pigs, and asked him to remain a few days longer till they should collect a still larger present in return for his kindness; but, as he found out their intention was to take the schooner, and knock himself and crew on the head, he made off in the night. But he maintains to this day that "virtue is its orn reward"-" at least 'tis so at Taranaki." Virtue, however, must have been on a visit to some other country, (she does go out sometimes,) when I saw and heard a British subject, a slave to some natives on the West Coast, begging hard for somebody to buy him. The price asked was one musket, but the only person on board the ressel possessing those articles preferred to invest in a different commodity. The consequence was, that the above-mentioned unit of the great British nation lived, and ("Rule Britannia" to the contrary notwithstanding) died a slare; but whether he was buried, deponent sayeth not.

My old rangatira at last began to shor signs that his time to leave this world of care was approaching. He had arrived at a great age, and a rapid and general breaking up of his strength became plainly observable. He often grumbled that men should grow old, and oftener that no great war broke out in which he might make a final display, and die with éclât. The last two years of his life were spent 
almost entirely at my house, which, however, he never entered. He would sit whole days on a fallen puriri near the house, with his spear sticking up beside him, and speaking to no one, but sometimes humming in a low droning tone some old ditty which no one knew the meaning of but himself, and at night he would disappear to some of the numerous nests or little sheds he had around the place. In summer he rould roll himself in his blanket and sleep anywhere, but no one could tell exactly where. In the hot days of summer, when his blood I suppose got a little warm, he would sometimes become talkative, and recount the exploits of his youth. As he warmed to the subject he would seize his spear and go through all the incidents of some famous combat, repeating every thrust, blow, and parry as they actually occurred, and going through as much exertion as if he was really and truly fighting for his life. He used to go through these pantomimic labours as a duty whenever he had an assemblage of the young men of the tribe around him, to whom, as well as to myself, he was most anxious to communicate that which he considered the most valuable of all knowledge, a correct idea of the uses of the spear, a weapon he really used in a most graceful and scientific manner; but he would ignore the fact that "Young New Zealand" had laid down the weapon for ever, and already matured a new system of warfare adapted to their new weapons, and only listened to his lectures out of respect to himself and not for his science. At 
last this old lion was taken seriously ill and removed permanently to the village, and one evening a smart handsome lad, of about twelve years of age, came to tell me that his tupuna was dying, and had said he would "go" to-morrow, and had sent for me to see him before he died. The boy also added that the tribe were $k a$ poto, or assembled, to the last man around the dying chief. I must here mention that, though this old rangatira was not the head of his tribe, he had been for about half a century the recognized war chief of almost all the sections or hapu of a very numerous and warlike $i w i$ or tribe, who had now assembled from all their distant villages and pas to see him die. I could not, of course, neglect the invitation, so at daylight next morning I started on foot for the native village, which I, on my arrival about mid-day, found crowded by a great assemblage of natives. I was saluted by the usual haere mai! and a volley of musketry, and I at once perceived that, out of respect to my old owner, the whole tribe from far and near, hundreds of whom I had never seen, considered it necessary to make much of me,at least for that day,-and I found myself consequently at once in the position of a "personage." "Here comes the pakeha!-his pakeha!-make way for the pakeha! - kill those dogs that are barking at the pakeha!" Bang! bang! Here a double barrel nearly blew my cap off by way of salute. I did for a moment think my head was off. I, however, being quite au fait in Maori etiquette by this time, thanks to the instructions and example of my old 
friend, fixed my eyes with a vacant expression looking only straight before me, recognized nobody, and took notice of nothing, not even the muskets fired under my nose or close to my back at every step, and each, from having four or five charges of powder, making a report like a cannon. On I stalked, looking neither to the right or the left, with my spear walking-staff in my hand, to where I saw a great crowd, and where I of course knew the dying man was. I walked straight on, not even pretending to see the crowd, as was "correct" under the circumstances; I being supposed to be entranced by the one absorbing thought of seeing "mataora," or once more in life my rangatira. The crowd divided as I came up, and closed again behind me as I stood in the front rank before the old chief, motionless, and, as in duty bound, trying to look the image of mute despair, which I flatter my'self I did to the satisfaction of all parties. The old man I saw at once was at his last hour. He had dwindled to a mere skeleton. No food of any kind had been prepared for or offered to him for three days; as he was dying it was of course considered unnecessary. At his right side lay his spear, tomahawk, and musket. (I never saw him with the musket in his hand all the time I knew him.) Over him was hanging his greenstone mere, and at his left side, close, and touching him, sat a stout, athletic sarage, with a countenance disgustingly expressive of cunning and ferocity, and who, as he stealthily marked me from the corner of his eye, I recognized as one of those limbs of Satan, a Maori 
tohunga. The old man was propped up in a reclining position, his face towards the assembled tribe, who were all there waiting to catch his last words. I stood before him, and I thought I perceived he recognized me. Still all was silence, and for a full half hour we all stood there, waiting patiently for the closing scene. Once or twice the tohunga said to him in a very loud voice, "The tribe are assembled, you won't die silent?" At last, after about half an hour, he became restless, his eyes rolled from side to side, and he tried to speak, but failed. The circle of men closed nearer, and there was evidence of anxiety and expectation amongst them, but a dead silence was maintained. At last, suddenly, without any apparent effort, and in a manner which startled me, the old man spoke clearly out, in the ringing metallic tone of voice for which he had been formerly so remarkable, particularly when excited. He spoke. "Hide my bones quickly where the enemy may not find them: hide them at once." He spoke again"Oh my tribe, be brave! be brave that you may live. Listen to the words of my pakeha; he will unfold the designs of his tribe." This was in allusion to a very general belief amongst the natives at the time, that the Europeans designed sooner or later to exterminate them and take the country, a thing the old fellow had cross-questioned me about a thousand times; and the only way I could find to ease his mind was to tell him that if ever I heard any such proposal I would let him know, protesting at the same time that no such intention existed. This notion of 
the natives has since that time done much harm, and will do more, for it is not yet quite given up. He continued-" I give my mere to my pakeha,"-_" my two old wives will hang themselves,"-(here a howl of assent from the two old women in the rear rank) - "I am going; be brare, after I am gone." Here he began to rave; he fancied himself in some desperate battle, for he began to call to celebrated comrades who had been dead forty or fifty years. I remember every word-"Charge!" shouted he"Charge! Wata, charge! Tara, charge! charge!" Then after a short pause-" Rescue! rescue! to my rescue! ahau! ahau! rescue!" The last cry for "rescue" was in such a piercing tone of anguish and utter desperation, that involuntarily I advanced a foot and hand, as if starting to his assistance; a morement, as I found afterwards, not unnoticed by the superstitious tribe. At the same instant that he gave the last despairing and most agonizing cry for " rescue," I saw his eyes actually blaze, his square jaw locked, he set his teeth, and rose nearly to a sitting position, and then fell back dying. He only murmured"How sweet is man's flesh," and then the gasping breath and upturned eye announced the last moment. The tohunga now bending close to the dying man's ear, roared out "Kai kotali lii te ao! Kia lootahi lii te ao! Kia liotahi ki te po!" The poor sarage was now, as I believe, past hearing, and gasping his last. "Kai kotali ki te ao!"-shouted the devil priest again in his car, and shaking his shoulder roughly with his hand-" Kia kotali lii te 
ao!-Kai kotahi ki te po!" Then giving a significant look to the surrounding hundreds of natives, a roar of musketry burst forth. Kai kotahi ki te ao! Thus in a din like pandemonium, guns firing, women screaming, and the accursed tohunga shouting in his ear, died "Lizard Skin," as good a fighting man as ever worshipped force or trusted in the spear. His death on the whole was thought happy, for his last words were full of good omen:- "How sweet is man's flesh."

Next morning the body had disappeared. This was contrary to ordinary custom, but in accordance with the request of the old warrior. No one, even of his own tribe, knows where his body is concealed, but the two men who carried it off in the night. All I know is that it lies in a cave, with the spear and tomahawk beside it.

The two old wives were hanging by the neck from a scaffold at a short distance, which had been made to place potatoes on out of the reach of rats. The shrivelled old creatures were quite dead. I was for a moment forgetful of the "correct" thing, and called to an old chief, who was near, to cut them down. He said, in answer to my hurried call, "by-and-bye; it is too soon yet; they might recover." "Oh," said I, at once recalled to my sense of propriety, "I thought they had been hanging all night," and thus escaped the great risk of being thought a mere meddling pakeha. I now perceived the old chief was employed making a stretcher, or kauhoa, to carry the bodies on. At a short distance also were five old creatures of women, 
sitting in a row, crying, with their eyes fixed on the hanging objects, and everything was evidently going on selon le règles. I walked on. " $E$ tika ana," said I, to myself. "It's all right, I dare say."

The two young wives had also made a desperate attempt in the night to hang themselves, but had been prevented by two young men, who, by some unaccountable accident, had come upon them just as they were stringing themselves up, and who, seeing that they were not actually "ordered for execution," by great exertion, and with the assistance of several female relations, who they called to their assistance, prevented them from killing themselves out of respect for their old lord. Perhaps it was to revenge themselves for this meddling interference that these two young women married the two young men before the year was out, and in consequence of which, and as a matter of course, they were robbed by the tribe of everything they had in the world, (which was not much,) except their arms. They also had to fight some half dozen duels each with spears, in which, however, no one was killed, and no more blood drawn than could be well spared. All this they went through with commendable resignation; and so, due respect having been paid to the memory of the old chief, and the appropriators of his widows duly punished according to law, further proceedings were stayed, and everything went on comfortably. And so the world goes round. 


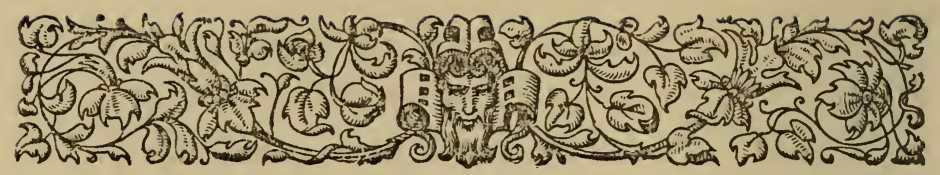

\section{Cinapter XV.}

Mana._-Young New Zealand.-The law of England._-"Pop goes the weasel."-Right if we have might.-God save the Queen.-Good advice.

fr. what I had heard and seen. "Surely," thought I, "if one half of the world does not know how the other half live, neither do they know how they die."

Some days after this a deputation arrived to deliver up my old friend's mere. It was a weapon of great mana, and was delivered with some little ceremony. I perceive now I have written this word mana several times, and think I may as well explain what it means. I think this the more necessary as the word has been bandied about a good deal of late years, and meanings often attached to it by Europeans which are incorrect, but which the natives sometimes accept because it suits their purpose. This same word mana has several different meanings, and the difference between these diverse meanings is sometimes very great, and sometimes only a mere shade of meaning, though one very necessary to observe; and it is, 
therefore, quite impossible to find any one single word in English, or in any other language that I have any acquaintance with, which will give the meaning of mana. And, moreover, though I myself do know all the meanings and different shades of meaning properly belonging to the word, I find a great difficulty in explaining them; but as I hare begun, the thing must be done. It will also be a tough word disposed of to my hand, when I come to write my Maori dictionary, in a hundred rolumes, which, if I begin soon, I hope to have finished before the Maori is a dead language.

Now then for mana. Virtus, prestige, authority, good fortune, influence, sanctity, luck, are all words which, under certain conditions, give something near the meaning of mana, though not one of them give it exactly; but before I am done, the reader shall have a reasonable notion (for a pakeha) of what it is.

Mana sometimes means a more than natural virtue or power attaching to some person or thing, different from and independent of the ordinary natural conditions of either, and capable of either increase or diminution, both from known and unknown causes. The mana of a priest or tohunga is proved by the truth of his predictions, as well as the success of his incantations, which same incantations, performed by another person, of inferior mana, would have no effect. Consequently, this description of mana is a virtue, or more than natural or ordinary concition attaching to the priest himself, and which 
he may become possessed of and also lose without any volition of his own. When

\section{"Apollo from his shrine, \\ No longer could divine,}

The hollow steep of Delphos sadly leaving,"-

Then the oracle had lost its mana.

Then there is the doctor's mana. The Maori doctors in the old times did not deal much in "simples," but they administered large doses of mana. Now when most of a doctor's patients recovered, his mana was supposed to be in full feather; but if, as will happen sometimes to the best practitioners, a number of patients should slip through his fingers seriatim, then his mana was suspected to be getting weak, and he would not be liable to be "knocked up" as frequently as formerly.

Mana in another sense is the accompaniment of power, but not the power itself; nor is it even in this sense exactly " authority," according to the strict meaning of that word, though it comes very near it. This is the chief's mana. Let him lose the power, and the mana is gone; but mind you do not translate mana as power; that won't do: they are two different things entirely. Of this nature also is the mana of a tribe; but this is not considered to be the supernatural kind of mana.

Then comes the mana of a warrior. Uninterrupted success in war proves it. It has a slight touch of the supernatural, but not much. Good fortune comes near the meaning, but is just a little too weak. The 
warrior's mana is just a little something more than bare good fortune; a severe defeat would shake it terribly; two or three in succession would show that it was gone: but before leaving him, some supernaturally ominous occurrence might be expected to take place, such as are said to have happened before the deaths of Julius Casar, Marcus Antonius, or Brutus. Let not any one smile at my, even in the most distant way, comparing the old Maori warriors with these illustrious Romans, for if they do, I shall answer that some of the old Maori Toa were thought as much of in their world, as any Greek or Roman of old was in his; and, moreover, that it is my private opinion, that if the best of them could only have met my friend "Lizard Skin," in his best days, and would take off his armour and fight fair, that the aforesaid "Lizard Skin" would have tickled him to his heart's content with the point of his spear.

A fortress often assailed but never taken has a mana, and one of a high description too. The name of the fortress becomes a pepeha, a war boast or motto, and a war cry of encouragement or defiance, like the slogan of the ancient Highlanders in Scotland.

A spear, a club, or a mere, may have a mana, which in most cases means that it is a lucky weapon which good fortune attends, if the bearer minds what he is about; but some weapons of the old times had a stronger mana than this, like the mana of the enchanted weapons we read of in old romances or fairy tales. Let any one who likes give an English word for this kind of mana. I have done with it. 
I had once a tame pig, which, before heavy rain, would always cut extraordinary capers and squeak like mad. Every pakeha said he was "weatherwise;" but all the Maori said it was a "poaka whai mana," a pig possessed of mana; it had more than natural powers and could foretell rain.

If ever this talk about the good old times be printed and published, and every one buy it, and read it, and quote it, and believe every word in it, as they ought, seeing that every word is true, then it will be a puka puka whai mana, a book of mana; and I shall have a high opinion of the good sense and good taste of the New Zealand public.

When the law of England is the law of New Zealand, and the Queen's writ will run, then both the Queen and the law will have great mana; but I don't think either will ever happen, and so neither will have any mana of consequence.

If the reader has not some faint notion of mana by this time, I can't help it; I can't do any better for him. I must confess I have not pleased myself. Any European language can be translated easily enough into any other; but to translate Maori into English is much harder to do than is supposed by those who do it every day with ease, but who do not know their own language or any other but Maori perfectly.

I am always blowing up "Young New Zealand," and calling them "reading, riting, rethmatiking" vagabonds, who will never equal their fathers; but I mean it all for their own good-(poor things!)-like a father scolding his children. But one does get 
rexed sometimes. Their grandfathers, if they had no backs, had at least good legs, but the grandsons can't walk a day's journey to sare their lives; they must ride. The other day I saw a young chap on a good horse; he had a black hat and polished Wellingtons; his hat was cocked knowingly to one side; he was jogging along, with one hand jingling the money in his pocket; and may I never see another war dance, if the hardened villain was not whistling "Pop goes the weasel !" What will all this end in?

My only hope is in a handy way (to give them their due) which they have with a tupara; and this is why I don't think the law will have much mana here in my time,-I mean the pakeha law; for to say the worst of them, they are not yet so far demoralized as to stand any nonsense of that kind, which is a comfort to think of. I am a loyal subject to Queen Victoria, but I am also a member of a Maori tribe; and I hope I may never see this country so enslaved and tamed that a single rascally policeman, with nothing but a bit of paper in his hand, can come and take a rangatira away from the middle of his hapu, and have him hanged for something of no consequence at all, except that it is against the law. What would old "Lizard Skin" say to it? His grandson certainly is now a magistrate, and if anything is stolen from a pakeha, he will get it back, if he can, and won't stick to it, because he gets a salary in lieu thereof; but he has told me certain matters in confidence, and which I therefore cannot disclose. I can only hint there was something said about the law, and driving the pakeha into the sea. 
I must not trust myself to write on these matters. I get so confused, I feel just as if I was two different persons at the same time. Sometimes I find myself thinking on the Maori side, and then just afterwards wondering if "we" can lick the Maori, and set the law upon its legs, which is the only way to do it. I therefore hope the reader will make allowance for any little apparent inconsistency in my ideas, as I really cannot help it.

I belong to both parties, and I don't care a straw which wins; but I am sure we shall have fighting. Men must fight; or else what are they made for? Twenty years ago, when I heard military men talking of "marching through New Zealand with fifty men," I was called a fool because I said they could not do it with five hundred. Now I am also thought foolish by civilians, because I say we can conquer New Zealand with our present available means, if we set the right way about it (which we won't). So hurrah again for the Maori! We shall drive the pakeha into the sea, and send the law after them! If we can do it, we are right; and if the pakeha beat us, they will be right too. God save the Queen!

So now, my Maori tribe, and also my pakeha coun'trymen, I shall conclude this book with good advice; and be sure you take notice; it is given to both parties. It is a sentence from the last speech of old "Lizard Skin." It is to you both. "Be brave, that you may live."

VERBUM SAPIENTI. 


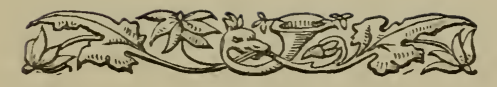

HISTORY OF THE WAR IN THE NORTH

OF NEW ZEALAND AGAINST

\section{THE CHIEF HEKE,}

IN THE YEAR 1845;

TOLD BY AN OLD CHIEF OF THE

NGGAPUHI TRIBE. 


\section{PREFACE.}

HIS little tale is an endeavour to call back some shadows

from the past: a picture of things which have left no record but this imperfect sketch. The old settlers of New Zealand-my fellow pioneers-will, I hope, recognize the likeness. To those who have more recently sought these shores, I hope it may be interesting. To all it is respectfully presented. 


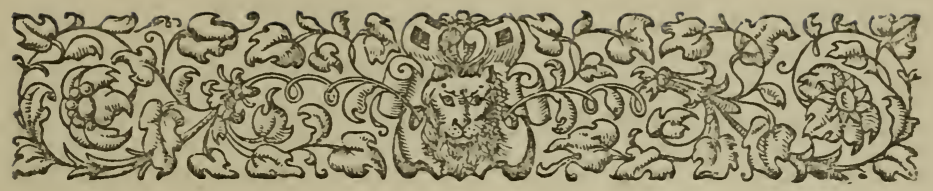

HISTORY OF THE WAR IN THE NORTH OF NEW ZEALAND AGAINST THE CHIEF HEKE.

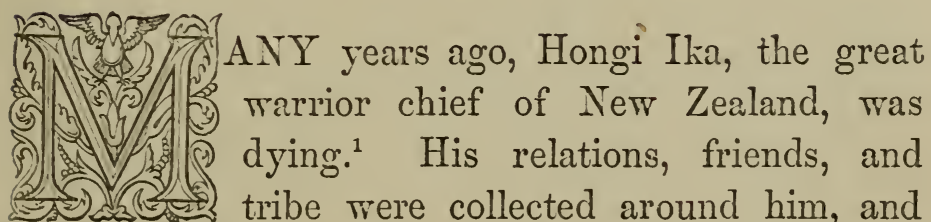
he then spoke to them in these words: "Children and friends, pay attention to my last words. After I am gone, be kind to the missionaries, be kind also to the other Europeans; welcome them to the shore, trade with them, protect them, and live with them as one people; but if ever there should land on this shore a people who wear red garments, who do no work, who neither buy nor sell, and who always havo arms in their hands, then be aware that these are a people called soldiers, a dangerous people, whose only occupation is war. When you see them, make war

1 Hongi was shot through the body at Mangamuka, in Holianga, of which wound he died, after lingering some years. The speech here given was not spolen on the day of his death, but some time before, when he saw he could not recorer. 
against them. Then, $\mathrm{O}$ my children, be brave! then, $\mathrm{O}$ friends, be strong! Be brave that you may not be enslaved, and that your country may not become the possession of strangers." And having said these words, he died.

After this, years passed away, and the pakeha increased in numbers, and were spread over the whole country, and traded with the Maori, and lived with them, and the Maori were pleased with them, for they got from them plenty of gunpowder, and tomahawks, and blankets, and all the wealth of the pakeha became theirs, and there was no fighting between them, but all lived together as friends.

More years passed away, and then came a chief of the pakeha who we heard was called a Governor. We were very glad of his arrival, because we heard he was a great chief, and we thought, he being a great chief, would have more blankets and tobacco and muskets than any of the other pakeha people, and that he would often give us plenty of these things for nothing. The reason we thought so was because all the other pakeha often made us presents of things of great value, besides what we got from them by trading. Who would not have thought as we did?

The next thing we heard was, that the Governor was travelling all over the country with a large piece of paper, asking all the chiefs to write their names or make marks on it. We heard, also, that the Ngapuhi chiefs, who had made marks or written on that paper, had been given tobacco, and flour, and sugar, and many other things, for having done so. 
We all tried to find out the reason why the Governor was so anxious to get us to make these marks. Some of us thought the Governor wanted to bewitch all the chiefs, ${ }^{1}$ but our pakeha friends laughed at this, and told us that the people of Europe did not know how to bewitch people. Some told us one thing, some another. Some said the Governor only wanted our consent to remain, to be a chief over the pakeha people; others said he wanted to be chief over both pakeha and Maori. We did not know what to think, but were all anxious he might come to us soon; for we were afraid that all his blankets, and tobacco, and other things would be gone before he came to our part of the country, and that he would have nothing left to pay us for making our marks on his paper.

Well, it was not long before the Governor came, and with him came other pakeha chiefs, and also people who could speak Maori; so we all gathered together, chiefs and slaves, women and children, and went to meet him; and when we met the Governor, the speaker of Maori told us that if we put our names,

1 The Governor made some presents of no great value to some of the natives who signed the Treaty of Waitangi, and a report in consequence got about, as is related here, that he was paying a high price for signatures. Many suppositions and guesses were made by the ignorant natives of the part of the country alluded to in the story, as to what could be the reason he was so desirous to get these names written on his paper, and many sugrested that he had some sinister design, probably that of bervitching them. 
or even made any sort of a mark, on that paper, the Governor would then protect us, and prevent us from being robbed of our cultivated land, and our timber land, and everything else which belonged to us. Some of the people were very much alarmed when they heard this, for they thought that perhaps a great war expedition was coming against us from some distant country, to destroy us all; others said he was only trying to frighten us. The speaker of Maori then went on to tell us certain things, but the meaning of what he said was so closely concealed we never have found it out. ${ }^{1}$ One thing we understood well, however; for he told us plainly that if we wrote on the Governor's paper, one of the consequences would be that great numbers of pakeha would come to this country to trade with us, that we should have abundance of valuable goods, and that before long there would be great towns, as large as Kororareka, in every harbour in the whole island. We were very glad to hear this; for we never could up to this time get half muskets or gunpowder enough, or blankets,

1 When a native says anything for which he thinks he may at some future time be called to account, he so wraps his ideas up in figurative and ambiguous terms as to leave him perfectly free, should he think fit, to give a directly contrary meaning to that which is most obvious at the time he speaks. Some natives are very clever at this, but it often happens that a fellow makes such a bungle of the business as to leare no meaning at all of any sort. This is what the narrator of the story means when he says, "the meaning of what the speaker of Maori said wias closely concealed," which is a polite Maori way of saying that he was talking nonsense. 
or tobacco, or axes, or anything. We also believed what the speaker of Maori told us, because we saw that our old pakeha friends who came with us to see the Governor believed it.

After the speaker of Maori had ceased, then Te Tao Nui and some other chiefs came forward and wrote on the Governor's paper; and Te Tao Nui went up to the Governor, and took the Governor's hand in his and licked it! We did not much like this; we all thought it so undignified. We were very much surprised that a chief such as Te Tao Nui should do so; but Te Tao Nui is a man who knows a great deal about the customs of the pakeha; he has been to Port Jackson in a ship, and he, seeing our surprise, told us that when the great pakeha chiefs go to see the King or Queen of England they do the same, so we sarv then that it was a straight proceeding. But after Te Tao Nui and other chiefs had made marks and written on the Governor's paper, the Gorernor did not give them anything. We did not like this, so some other chiefs went forward, and said to the Governor, "Pay us first, and we will write afterwards." A chief from Omanaia said, "Put money in my left hand, and I will write my name with my right," and so he held out his hand to the Governor for the money; but the Governor shook his head and seemed displeased, and said he would not pay them for writing on the paper.

Now, when all the people saw this they were very much rexed, and began to say one to another, "It is wasting our labour coming here to see this Governor," 
and the chiefs began to get up and make speeches. One said, "Come here, Governor; go back to England;" and another said, "I am Governor in my own country, there shall be no other ;" and Paapahia said, "Remain here and be Governor of this island, and I will go to England and be King of England, and if the people of England accept me for their King it will be quite just; otherwise you do not remain here." Then many other chiefs began to speak, and there was a great noise and confusion, and the people began to go away, and the paper was lying there, but there was no one to write on it. The Governor looked vexed, and his face was very red. At this time some pakehas went amongst the crowd, and said to them, "You are foolish; the Governor intends to pay you when all the writing is done, but it is not proper that he should promise to do so; it would be said you only wrote your names for pay; this, according to our ideas, would be a very wrong thing." When we heard this we all began to write as fast as we could, for we were all very hungry with listening and talking so long, and we wanted to go to get something to eat, and we were also in a hurry to see what the Governor was going to give us; and all the slaves wanted to write their names, so that the Governor might think they were chiefs, and pay them; but the chiefs would not let them, for they wanted all the payment for themselves. I and all my family made our marks, and we then went to get something to eat; but we found our food not half done, for the women and slaves who should have looked after the cooking were all mad 
about the Governor, so when I saw that the food was not sufficiently done, I was aware that something bad would come of this business. ${ }^{1}$

Next morning the things came with which the Governor intended to pay us for writing our names, but there was not much tobacco, and only few blankets $;^{2}$ and when they were divided some of the chiefs had nothing, others got only a few figs of tobacco, some one blanket, others two. I got for myself and all my sons, and my two brothers, and my three wives, only two blankets. I thought it was too little, and was going to return them, but my brother persuaded me to keep them; so we got into our canoe to go home, and on the way home we began to say, "Who shall have the blankets?" And so we began to quarrel about them. One of my brothers then said, "Let us cut them in pieces, and give every one a piece." I saw there was going to be a dispute about them, and said, "Let us send them back." So we went ashore at the house of a pakeha, and got a pen and some paper, and my son, who could write, wrote a letter for us all to the Governor, telling him to take back the blankets, and to cut our names out

1 This is a common native superstition. The natives beliere in omens of a thousand different kinds, and amongst others think it a very bad omen if, on an occasion when any business of importance is on hand, the food happens to be serred underdone; or before a battle it is a particularly bad omen.

: These presents were given to the natives, and, in their matter-of-fact manner, understood to be payment for signing the treaty. 
of the paper, and then my two brothers and my sons went back and found the Governor in a boat about to go away. He would not take back the blankets, but he took the letter. I do not know to this day whether he took our names out of the paper. It is, however, no matter; what is there in a few black marks? Who cares anything about them?

Well, after this, the Governor died; he was bewitched, as I have heard, by a tohunga at the South, where he had gone to get names to his paper; for this was his chief delight, to get plenty of names and marks on his paper. He may not have been bewitched, as I have heard, but he certainly died, and the paper with all the names was either buried with him, or else his relations may have kept it to lament over, and as a remembrance of him. I don't know. You, who are a pakeha, know best what became of it; but if it is gone to England, it will not be right to let it be kept in any place where food is cooked, or where there are pots or kettles, because there are so many chiefs' names in it; it is a very sacred piece of paper; it is very good if it has been buried with the Governor. ${ }^{1}$

After the first Governor came the second Governor, but the towns and numerous pakeha traders we expected did not come. We heard of a town at Waitamata having been built, ${ }^{2}$ and others farther South; but in our part of the country there was no new

1 The Treaty of Waitangi.

2 Auckland, the capital of New Zealand. 
towns, and the pakeha did not increase in numbers, but, on the contrary, began to go away to the town at Waitamata, to be near their chief the Gorernor, who lived there, and many of us had no one left to sell anything to as formerly. Tobacco began to be scarce and dear ; the ships began to leare off coming to Tokerau, Hokianga, and Mangonui. We inquired the reason of this, but the fer pakeha traders left amongst us told us different stories. Some said that the reason tobacco was scarce and dear was, because the Governor would not let it be brought on shore until he was paid a large price for it, besides what was paid to the people of the ship, who were the right owners of it. This we at first did not beliere, because you all said you trere not slares, not one of you, but all free men. Others said that the reason ships did not come as frequently as formerly, was because the Gorernor made them pay for coming to anchor in the ports. Some said all the evil was by reason of the flagstaff which the Gorernor had caused to be erected at Maiki, above Kororareka, as a rahui, and that as long as it remained there things would be no better; other's again told us the flagstaff was put there to show the ships the way into the harbour; others, that it was intended to keep them out; and others said that it was put up as a sign that this island had been taken by the Queen of England, and that the nobility and independence of the Maori was no more. But this one thing at least was true, we had less tobacco and ferrer blankets and other European goods than formerly, and we sam that the first Governor had not 
spoken the truth, for he told us we should have a great deal more. The hearts of the Maori were sad, and our old pakeha friends looked melancholy, because so few ships came to bring them goods to trade with. At last we began to think the flagstaff must have something to do with it, and so Heke went and cut it down.

When the flagstaff was cut down, there was a great deal of talk about it, and we expected there would be fighting; but it all ended quietly. The Governor, however, left off taking money from the people, ${ }^{1}$ and tobacco became cheap, and ships began to come as before, and all our old pakeha friends were glad, because they had "plenty of goods to sell us, and so we all thought Heke was a man of great understanding. But the Governor put up the flagstaff again, and when Heke heard this he came and cut it down again; so this was twice that he cut it down.

Now, when the Governor heard that Heke had cut down the flagstaff a second time, he became very angry, because he thought he could never get any more money from the people, or the ships, ${ }^{2}$ so he sent

1 After the flagstaff had been cut down, the customs-duties were repealed, and, in consequence, tobacco and other articles on which duties had been levied became cheaper. This fully convinced the natives that there was some mysterious connection between the dearness of different goods and the existence of the flagstaff, which they now thought was the source of all evils, and which will account for their determined persistence in cutting it down so often, at all risks.

2 This was really the belief of the natives at the time; I have heard it said not once but fifty times. To tell the contrary was 
to England, and to Port Jackson, and everywhere, for soldiers to come to guard the flagstaff, and to fight with Heke.

It was not long before the soldiers came, and the flagstaff was put up again; it was made larger and stronger than before, and pieces of iron were fastened to it, to prevent its being cut down easily, and a house was built under it for the soldiers, and the Governor told those soldiers to remain there always to guard that flagstaff. There were other soldiers at Kororareka and other places. I don't know how many, but a great many. This was the first time that Heke began to think of the last words of Hongi Ika, his relative, when he died at Mawhe. Heke began to think much on these words, for Heke was now a chief amongst the Ngapuhi, and he thought to stand in the place of Hongi, as, indeed, he had a right to do.

Now, these soldiers had red garments; they did not work, or buy and sell, like the other pakeha people; they practised every day with their weapons, and some of them were constantly watching as if they expected to be attacked every moment. They were a rery suspicious people, and they had stiff, hard things round their necks to keep their heads up, lest they should forget, and look too much downwards, and

perfectly useless; the flagstaff, and nothing but the flagstaff, was "the cause of all the eril "-and there were not wanting ill-disposed Europeans who encouraged this belief, as I think with the purpose to bring on a war. 
not keep their eyes continually rolling about in search of an enemy.

Great, indeed, was the fear of the Maori when they heard of these soldiers, for all the pakeha agreed in saying that they would attack any one their chief ordered them to attack, no matter whether there was any just cause or not; that they would fight furiously till the last man was killed, and that nothing could make them run away. Fear came like a cold fog on all the Ngapuhi, and no chief but Heke had any courage left. But Heke called together his people, and spoke to them saying, "I will fight these soldiers, I will cut down the flagstaff, I will fulfil the last words of Hongi Ika. Be not afraid of these soldiers, 'all men are men.' ${ }^{1}$ The soldiers are not gods; lead will kill them; and if we are beaten at last, we shall be beaten by a brave and noble people, and need not be ashamed."

So Heke sent runners to all the divisions of the Ngapuhi, saying, "Come, stand at my back; the red garment is on the shore. Let us fight for our country. Remember the last words of Hongi Ika-Kei hea koutou kia toa."

But the chiefs of the Ngapuhi hapu said amongst themselves, "How long will the fire of the Maori burn before it is extinguished?"

1 This is a native saying or proverb, meaning that in fact one man is as good as another, or that the best or bravest man is but a man, and therefore not to be too much feared. The speech is a literal verbatim translation. 
So the Ngapuhi chiefs would not join Heke for fear of the soldiers, but said, "We will wait till a battle has been fought, and if he is successful, then we will join him." So Heke, therefore, went with his own family and people, and those of his elder relation Kawiti, and the Kapotae, and some others, altogether about 400 men. He went to fight with the soldiers at Kororareka, and to cut down his old enemy the flagstaff.

Heke and Kawiti having arrived at Tokerau, and having fixed upon the day of attack, they agreed that Kawiti should attack the town of Kororareka, to draw off the attention of the soldiers who guarded the flagstaff on the hill of Maiki, so that Heke should have an opportunity to cut it down, for Heke had said that he would cut down the flagstaff, and he was resolved to make his word true. When they had formed this plan, and night was come, the priests of the war party threw darts to divine the event. ${ }^{1}$ They threw one for Heke, and one for the soldiers, and one for the flagstaff: and the dart for Heke went straight, and fair, and fortunate; but the dart for the soldiers turned to

1 Before a war or any other important matter, the natives used to have recourse to divination, by means of little miniature darts made of rushes or reeds, or often of the leaf of the cooper's flag (raupo). This was very much believed in, but of course the chiefs and priests or tolunga (such of them as did not deceive themselves) could make the result favourable or otherwise as they liked. There is an allusion to a custom of this kind (divining by darts) in the Bible. 
one side, and fell with the wrong side up; so did that for the flagstaff. When this was told the people they were very glad, and had no longer any fear. Then Kawiti, who is himself a tohunga, threw a rakau for his own path-he threw one for himself and people, and one for the soldiers, and one for the town. The dart for Kawiti went straight and fair, but it turned wrong side up, which is the omen of death; and so also did the dart for the soldiers go fair and straight, but also turned wrong side up. And when Kawiti saw this, he said, "It is good. Here have I two darts ominous of success, and bravery, and death-our enemy will prove very strong and brave, they will suffer much from us, and so will we from them. I am not displeased, for this is war and not play." Then Heke and Kawiti stood up in the night, and spoke long and with great spirit to their men, to give them courage; and when they had done speaking, Kawiti remained where he was near the sea, not far from the town; but Heke went inland, and before morning he lay with his men in a hollow close to the flagstaff.

Heke lay on the ground with his war party-close at hand were the sleeping soldiers. Amongst those soldiers there was not one tohunga, not a man at all experienced in omens, or they must have had some warning that great danger and defeat was near; but there they lay sleeping between the open jaws of war, and knew of no danger. This is the only foolishness I see about the pakeha-they are quite 
ignorant and inexperienced in omens, and, indeed, care nothing at all about them. ${ }^{1}$

In the morning, before it was light, Kawiti rushed upon Kororareka. The young men did not look for the light of this world; their only thought was who should kill the first man, and elevate his name. But the soldiers met them in the path, and the fight began. Pumuka then gained a name; he killed the first man of the battle, but had not long to rejoice, for he himself fell a mataika for the pakeha. ${ }^{2}$ Then the Maori charged to revenge Pumuka; the soldiers met them; the sailors charged sword in hand; a keen breeze of war was blowing then on Kororareka! The best men of both sides were in front; the sword met the tomahawk, and many fell; but of all the brares (toa) there, the chief of the sailors was the bravest; no man could stand up before his sword, and had he not been struck by a shot, the Maori would have been defeated-four men like him would have killed Kawiti and all his war party. This is what I have been told by Kawiti's people who were

1 It astonished the natives greatly that the soldiers paid no attention to omens, and also to see them every five minutes doing something or another monstrously "unlucky."

2 The first man killed in a battle is called the mataitia. T'o kill the matailia is thought a great distinction, and young men will risk themselves to the utmost to obtain it. Many quarrels arise sometimes after a fight, in consequence of different individuals claiming the honour of having killed the first man. The writer knows a man who in different battles has killed eleven inataika. 
in the fight. I did not see it myself, but was at every other fight in the war.

When Kawiti attacked Kororareka, the soldiers at the flagstaff on the top of Maiki heard the firing, and left the flagstaff, and went straggling about the hillside, trying to see what was going on below. They did not think of Heke or his words when he said he would cut down the flagstaff, neither did they remember the orders of the Governor. They were very foolish; for while they were trying to see the fight between Kawiti and the soldiers and sailors, and thinking, perhaps, that the Maori did not know how to conduct an ambush, Heke started from the ground, and before they could turn round the flagstaff and their fort was taken. Some of them were killed, others ran away, and then the axes went to work, and the flagstaff was cut down. So this was the third time it fell, and there it lies now.

During this time, the fighting was still going on at Kororareka; but at last the Maori drew back, and the pakeha remained in the town. The Maori were not beaten, neither were the soldiers. Pumuka had been killed, and many others of Kawiti's people were killed and wounded; several, also, of the pakeha had been killed, and their great toa, the chief of the sailors, was almost dead. So the words of Kawiti proved true: both he and his enemy had done bravely, and had equal success, and both had suffered much.

In the afternoon the Maori began to perceive that the pakeha were leaving the town, and going on 
board the ships, so they returned to the town and began to plunder, and the people of the town plundered also, so both parties quietly plundered the town of Kororareka, and did not quarrel with one another. At last, all the town people and soldiers went on board the ships, and then the ship of war fired at the Maori people who were plundering in the town. The noise of the firing of the ship guns was very great, and some of Kamiti's people were near being hit by the lumps of iron. This was not right, for the fight was over, and the people were only quietly plundering the town which had been left for them, and which they had given fair payment for; but, I suppose, the sailors thought their chief was dying, and fired a rolley (waipu) for his sake. So the sailors may have an argument in their farour; but the Maori did not at the time think of this, so in revenge they burnt Kororareka, and there was nothing left but ashes; and this was the beginning of the war.

Well, you pakeha are a noble-minded people; it was very generous of you to give up Kororareka to be plundered and burnt for utu for the Maori. If you had been beaten you could not have helped it; but as you were not beaten, I say it was very noble of you to give up the town. You are always giring us something, so you gave Kawiti and Heke a town full of blankets, and tobacco, and money, and all sorts of property, and rum! It was very good of you. I wish I had been there.

When Kororareka was burnt, and all the Euro- 
peans had sailed to the town at Waitamata, which we now began to hear was called Auckland, then Heke went to stop at Ahuahu, and the news of the battle was heard all over the country, and then many men came to join Heke, but no whole hapu came, for most of the Ngapuhi chiefs said, "Now tens of thousands of soldiers will come to fight with Heke, and he will be utterly destroyed." But when all Heke's people were together they were about 700 men.

Now, when Thomas Walker Nene heard that the war had actually begun, and that Kororareka had fallen, he called together his family and all his friends, and said he would fight against Heke, and seek revenge for his friends the pakeha people. Walker had been always a friend and protector to the Europeans; and also Hongi Ika, Heke's relation, had killed in former times Te Tihi, at Hokianga, and swallowed his eyes, and Te Tihi was a matua (elder relation) to Walker.

And Te Tao Nui came to join Walker, and brought with him all his family and relations, many fighting men; only one man of his family did not come-that man went to help Heke. Te Tao Nui had always, like Walker, been a good friend to the Europeans, and he was also an ancient enemy of Hongi Ika.

And the tribe of Ngati Pou came to help Walker. Formerly they had been a great tribe, but Hongi Ika had driven them from their country and slain most of their warriors; but they in return wounded Hongi, and he died of that wound some years afterwards. They came to help Walker, in search of 
revenge against Hongi Ika, for Heke and Hongi are the same. This tribe of Ngati Pou brought forty men to help Walker, which was all left alive by Hongi, but they fought well, for their hatred to Hongi was great; they fought through the whole war, and never were absent from any fight. The first man killed in the war between Walker and Heke was killed by a Ngati Pou, and the first man who fell on our side was a Ngati Pou, and the last man who fell in the war was also a Ngati Pou; their chief, Hakaraia, was wounded, and sereral others of the forty men were killed.

And all the young men of the Hikutu came to help Walker; they came to practise war, and elevate their names; but their handsome and brave young chief, Hauraki, fell at Waikare, for such is the appearance of war; and many young men came from different tribes (hapu) to join Walker, and to perfect themselves in the practice of war.

And I, your friend, went also with my two younger brothers, my four sons, and my daughter's husband, and nine cousins (teina keke), and three slavestwenty men of us, all tino tangata, who had seen war. ${ }^{1}$ I went because when the ancestors of Heke fought against mine, the ancestors of Walker came to help

1 This is a rery good example of the manner in which a natire chief raises men for a war party; they are all his relations with their different connections, and it is this which causes the natives to be so carcful to remember all who are, however remotely, related to them. In a word, to be "a man of many cousins" is to be a great chicf. 
my forefathers, because they were related to each other; so I and Walker are relations; but I don't know exactly what the relationship is, for eleven generations have passed since that ancient war; but Walker and I are aware that we are related, and always come to each other's help in war.

When Walker had got all his men together, they were in number about 500, and he went with them to Okaihau and built a pa, and Heke was at Te Ahuahu with his men. Te Ahuahu is not far from Okaihau, and there was fighting between them every day. Several of Walker's relations were killed, and the brother of Te Tao Nui was also killed, and his son badly wounded; but in every fight Heke lost most men, and had the worst of the battle. So Heke sent a messenger to Walker, saying, "If you go on this way, when the soldiers return there will be no one to fight them. Who will there be to fight with you, and who to fight the red garment?" But Walker said, in answer, "I will fight on till I arrive at the end."

Then the messenger answered Walker, saying, "Behold the soothsayers foretell your death."

Then arose quickly Karere Horo, our priest, who answered in a loud voice, saying, "Your soothsayers speak falsely. What sin has Walker committed that he should die in this war? I myself who now address you shall die, and many others, but Walker shall live."

Then Heke's messenger, having saluted the people, took his gun and departed.

Up to this time, no news had been heard from the 
Governor at Auckland, and a pakeha came to the camp at Okaihau, and said to Walker's people, "This is a bad thing you are doing, coming here to fight with Heke. The Governor when he hears of it will be angry, and so will the Queen. You are only wasting your powder, and getting killed for nothing. The Gorernor will not give you any more gunpowder, and you will get no pay. Moreover, you are not fighting at all for the pakeha, or the Queen, you are fighting to revenge Te Tihi." Then another pakeha who was in the camp, an old friend of Walker, arose and spoke to the people, and said, "Pay no attention to what has been said by this man. Both the Governor and the Queen will be well pleased to hear of your opposing Heke, and so will all the pakeha people. You will be ever after this looked on as true friends, and the Governor will give you plenty of gunpowder to replace what you have expended. Neither is this a war for Te Tihi, but for Kororareka; but if you remember Te Tihi also, how can you help it?" When we heard this speech we were encouraged, for we had begun to doubt whether we were doing right when we heard the speech of the first pakeha.

On this same night the moon was eaten into by a star (eclipsed), and the light of the moon was quite obscured, and we all thought this an omen of great disaster to one party or the other in the battle to take place next morning. The fight, however, in the morning was no great matter; of Heke's people there were three killed and twenty wounded; and eleven of our men were wounded, but none killed. 
Walker's old pakeha friends gave him gunpowder, and rifles, and other things, to enable him to fight Heke; and some of them came and stayed at the camp, and fought amongst his men, to show him that he was right in what he was doing, for Walker had not yet had any word from the Governor, and was only fighting on his own thought.

Shortly after this, a letter came from the Governor, and with it the Governor sent gunpowder, and lead, and blankets, and flour, and sugar, and tobacco; so we saw then clearly that we were doing right. But there was only one letter for both Walker and $\mathrm{Te}$ Tao Nui; so Te Tao Nui was angry at this, for he thought there should have been a letter entirely for himself, and he said he would leave the camp with all his men. He had more men, at that time, than Walker; but, however, he remained, and helped Walker to the last. After this, news came frequently from Auckland, and before long we heard that the soldiers were coming.

When Heke's people heard that the soldiers were coming, most of them left him, and there remained but 200 men. Then Heke left Te Ahuahu, and came and built a pa not far from Taumata Tutu, on the clear ground by the lake; for he said he would fight the soldiers on the spot where the last words of Hongi Ika had been spoken. The name of this pa of Heke's was Te Kahika.

Now, when this new fort of Heke's was finished, the spirit of the Ngakahi entered into the atua wera, who is the greatest tohunga in all the country of the 
Ngapuhi. So the Ngakahi spoke in the night to Heke and his people, by the mouth of the atua wera, "Be brave, and strong, and patient. Fear not the soldiers, they will not be able to take this fortneither be you afraid of all those different kinds of big guns you hare heard so much talk of. I will turn aside the shot, and they shall do you no harm; but this pa and its defenders must be made sacred (tapu). You must particularly observe all the sacred rites and customs of your ancestors; if you neglect this in the smallest particular, evil will befall you, and I also shall desert you. You who pray to the God of the missionaries, continue to do so, and in your praying see you make no mistakes. Fight and pray. Touch not the spoils of the slain, abstain from human flesh, lest the European God should be angry, and be careful not to offend the Maori gods It is good to have more than one God to trust to. This war party must be strictly sacred. Be brare, be strong, be patient." 1

So Heke waited there at his fort at Mawhe, near Taumata Tutu, for the coming of the soldiers; and before long they arrived at Walker's camp at Okaihau, which was but a short distance from where Heke was. When these soldiers arrived they were very much fatigued, and quite without prorisions,

1 This is word for word a literal translation of the speech of the atua wera to Heke's men. He was, howerer, supposed only to speak the words of the Ngalialii by whom he was at the moment inspired. 
and not at all fit to go to fight. They had been two nights on the road, one of which nights they lay out in the rain, and they had but a small quantity of ammunition. They had come by a long, bad road, up and down hill, though there was a good road open to them; and they were quite worn out, and not fit to fight at all. What could be the reason that the pakeha who knew the country did not tell the soldiers to come up the Keri Keri in boats, and then along the cart road to the turn-off to Okaihau? If they had done this, they could have brought big guns in the boats, and provisions, and put them in carts at the Keri Keri, and come along the cart road till they were not far from Walker's camp. If they had done this, the big guns would have knocked down the pa, for it was a very weak one, and it would have been taken, and the war would have ended; for it was because this very weak pa was not taken that the Maori kept on fighting, and caused so many men afterwards to be killed on both sides. Heke certainly had many friends amongst the Europeans, as why should he not?

But the soldiers had with them a light gun, called a rocket, and this gun had a great name: it was said that it would go into the pa, and twist and turn about in pursuit of the people until it had killed them every one. When we heard this we were sorry for Heke and his people, and were in great fear for ourselves lest it should turn round upon us also.

When the soldiers had rested one night at Okaihau, they prepared to attack Heke's pa; but early in the 
morning, when they were getting something to eat, we observed many of them eating standing up; this gave us a good deal of uneasiness, for it has an unlucky look to see warriors before going to battle eating their food standing. They should sit down and eat quietly, as if nothing was going to happen out of common; but, as I have said before, the soldiers are very inexperienced in these matters. When they had done eating, they formed to march to attack Heke. What a fine-looking people these soldiers are! Fine, tall, handsome people; they all look like chiefs; and their advance is like the advance of a flight of curlew in the air, so orderly and straight. And along with the soldiers came the sailors; they are of a different family, and not at all related to the soldiers,${ }^{1}$ but they are a brave people, and they came

1 That the sailors were quite a different hapu, though belonging to the iwi of England, and in no way "related" to the soldiers, I have heard often stated by the natives, as well as by the narrator of this story. Neither will we wonder at their having jumped at this conclusion, after having compared "Jack," let loose for a run on shore, with the orderly soldiers. I will here take occasion to state that I shall not hold myself accountable for the many mistakes and misapprehensions of my old friend the Ngapuhi chief, when he speaks of us, our manners, customs, and motives of action; when he merely recounts the events and incidents of the war, he is to be fully depended on, being both correct and minutely particular in his relation, after the native manner of telling a story, to omit nothing. I have had, indeed, to leare out a whole rolume of minute particulars, such as this for instance: where a pakeha would simply say, "we started in the morning after breakfast," \&c., the native would say, "in the morning the ovens were heated, and the food 
to seek revenge for the relations they had lost in the fight at Kororareka. They had different clothes from the soldiers, and short guns, and long heary swords; they were a people who talked and laughed more than the soldiers, and they flourished their guns about as they advanced, and ate tobacco.

So the soldiers, sailors, and other Europeans advanced to the attack of Heke's pa, and with them

was put in and covered up; when it was cooked it was taken out, and we eat it, and finished eating, then we got up and started," \&c. In the course of the narration I have translated, I have had to listen to the above formula about fifty times; the lighting of a pipe and the smoking it, or the seeing a wild pig (describing size and colour, \&c.), is never omitted, no matter if it is five seconds before commencing a battle. This is the true native way of telling a story, and it is even now a wonder to them to see how soon a European tells the story of a journey, or voyage, or any event whatever. If a native goes on a journey of three days' duration, during which nothing whatever of any consequence may have occurred, it will take him at least one whole day to tell all about it, and he is greatly annoyed at the impatient pakeha who wants to get the upshot of the whole story by impertinently saying, "Did you get what you went for ?" To tell that too soon would be out of all rule; every foot of the way must be gone over with every incident, however trivial, before the end is arrived at. They are beginning now to find that in talking to Europeans they must leave out one half at least of a story to save time, but the old men can't help making the most of a chance of talking. To cut a story short seems to them a waste of words by not speaking them, while we think it a decided waste of words to speak them. In old times the natives had so few subjects for conversation that they made the most of what they had, which accounts for their verbosity in trifling matters. 
came also Walker and his men; but before we had gone far, we observed the soldiers carrying on their shoulders certain things made of cloth and wood; these things were rolled up, and we did not know the use of them, so we asked what they were, and were told they were kauhoa on which to carry the dead or wounded! This was the worst of all; there were those soldiers going to battle, and actually carrying on their shoulders things to put themselves on when they were dead! So we began to say one to another, "Those soldiers walking there are all dead men. It only wants a few guns to be fired, and they will be all killed." So some of the chiefs told some of the chiefs of the soldiers what a dreadfully unlucky thing they were doing, but they all laughed, and said that they came there to fight, and that whenever people fought some one was sure to be killed or wounded, and that it was right to have something to carry them on. But our people said it was time enough to think of carrying a man when he could not stand, and that by what they were doing they were calling for death and destruction; and they tried hard to get the soldiers to throw away these things, but the soldiers would not listen to them. So we all said, "This is not a war party here marching on this plain, but a mate (a funeral procession); so all the Maori left the soldiers, and went and sat on the top of the hill called Taumata Kakaramu, except about forty men, Walker's relations, who would not leave him. We felt sorry for the soldiers; but we said, "Let them fight their own 
battle to-day, and if they are successful we will help them in every other fight." But no one could believe they would be successful.

At last the soldiers and sailors got before Heke's $\mathrm{pa}$; the main body of the soldiers remained opposite to it, at the side next to Walker's camp-the rest, about one hundred men, sailors and soldiers, went round by the shore of the lake, which was on the right of the pa, and so got behind it; and on that side there was but one slight fence, and no pekerangi. ${ }^{1} \quad$ The soldiers had told us in the morning that they would rush on both sides of the pa at once, and that it would be taken in a moment, and that then they would come home to breakfast.

So now the soldiers were in front of the $\mathrm{pa}$, and also behind it; and on the right was the lake, and on the left was Walker with about forty men, and behind Walker there was a wood-he was between the wood and the pa.

Then the soldiers who had the rocket gun went a

1 Heke's pa at the lake, the first we erer attacked, was the weakest ever built by the natives in the war. Had it not been for Kawiti's appearance just at the moment the storming party were about to advance, and thus making a diversion, it would most certainly have been taken, and as certain all its defenders killed or taken prisoners; for if the soldiers had entered then, the friendly natives, who were outside in great numbers, would have prevented any escaping. As it turned out, however, the place was not taken, and this gare the natives courage to continue the war, in the course of which they acquired so much confidence, that now they think less of fighting Europeans, and are less afraid of them, than of their own countrymen. 
little to the left front of the pa, and set the gun upon its legs, and pointed it straight at the pa. Then all the people on the top of Taumata Kakaramu fixed their eyes on this gun. We watched it closely, and held our breath, and had great fear for the people in the pa-for they were, although against us, all Ngapuhi, the same iwi as ourselves, and many of them our near relations-and we nevier expected to see them more by reason of this gun, we had heard so much of it. At last, a great smoke was seen to issue from one end of the gun, and the rocket came out of the other. At first it did not go very fast, but it had not gone far before it began to flame, and roar, and dart straight towards the pa. It had a supernatural appearance, and rushed upon the pa like a falling star; but just as it was about to enter the pa it swerved from its course, touched the ground outsice, and then rose and flew away over the pa, without doing any harm, and no one could tell where that first rocket went to, for it was the Ngakahi, the familiar spirit of the atua wera, who had blown upon it with his breath and turned it away, according to his word when he spoke by the mouth of the tolunga; for up to this time Heke and his people had kept strictly all the sacred customs, and infringed none of them. So the Ngakaki remained guarding them from all danger.

When we sar that the first rocket had gone by the pa and done no harm, we all gave a great sigh, and our minds were eased; a second rocket was fired, and a third, and so till they were all gone, but 
not one did any harm, for the Ngakahi had turned them all away-not one entered the pa.

Now, before the first rocket was fired, Heke came out of the front gate of the pa to watch the effect of the rocket, and he stood outside praying a Maori prayer, and holding with one hand to a post of the funce. Then the first rocket was fired; it came very near him, and passed away without doing any harm. Then another was fired, and missed also; so when Heke saw this, he cried out in a loud voice, "What prize can be won by such a gun?"1 and this has become a saying amongst us from that day; for whenever we hear a man boasting of what he can do, we think of the rocket, and cry, "What prize can be won by such a gun?"

When the first rocket was fired it frightened all the dogs in the pa, and they ran barking away over the plain; and also one slave ran out of the pa. He was very much frightened, and he ran away by a path which went between the hundred soldiers and sailors who were behind the pa, and Walker's people, who were at the left side of it; and this slave never stopped running till he came to a place called Kai Namu, where Kawiti, who had marched all night to relieve Heke, had just arrived. And this slave ran up to Kawiti and his people, and began to cry

1 " $E$ aha te liai e pahure $i$ aia." My translation is not rery literal; a literal translation would not give the sense to the reader not acquainted with the Maori language; my free trans. lation gives it exactly. 
out, "Oh, the soldiers have a frightful gun; it comes roaring and flaming." Here Kawiti stopped him, and said, "I know all about all sorts of guns; all guns will kill, and all guns will also miss; this is the nature (ahua) of guns; but if you say one word more, I will split your head with my tomahawk." So the slave became more afraid of Kawiti than he was of the rocket, and he ran away back to Heke, and told him that Kawiti with help was close at hand.

When all the rockets had been fired, then the hundred men, soldiers and sailors, who were at the back of the pa, arose out of an old Maori pare pare, where they had been sheltered, and giving a great shout, turned to rush against the pa. Then Heke shouted to his men, "Now let every man defend the spot he stands on, and think of no other; and I, on my side, will look to the great fish which lies extended on our front." ${ }^{1}$ And as Heke was saying this, the soldiers

1 The natives often call a line or column of men a fish, and this term is just as well understood as our "column," "company," "battalion," \&c. I will here say that though the native language is, as might be supposed, extremely deficient in terms of art or science in general, jet it is quite copious in terms relating to the art of war. There is a Maori word for almost every infantry movement and formation. I have also been very much surprised to find that a native can, in terms well understood, and without any hesitation, give a description of a fortification of a very complicated and scientific kind, having set technical terms for every part of the whole- "curtain, bastion, trench, hollow way, traverse, outworks, citadel," \&c. \&c., being all well-known Maori words, which every boy knows the full meaning of. 
and sailors had begun to move towards the pa, when suddenly Kawiti with one hundred and forty men appeared close upon their right, and fired upon them. Then the soldiers turned quickly to the right and attacked Kawiti; they were close to each other, and some fought hand to hand. The soldiers, then, were pressed back, and forced to give way before the rush of Kawiti and his men; but soon they rallied to the call of their chiefs, and charged with the bayonet, and then a close fight ensued, in which twenty of Kawiti's men were slain, and many wounded. Several of them were chiefs, and among them was one of Kawiti's sons, being the second son he had lost in the war; the other fell at Kororareka. Kawiti's men then retreated, and the soldiers chased them as far as the path in the hollow, which leads to Ahuahu, and there the last Maori was killed by the foremost soldier. There is a stone placed there where that Maori fell, and close to that stone by the side of the path the soldier is also buried, for a shot from the pa struck him, and he fell there. He was a great toa, that soldier; in this fight whenever he pointed his gun a man fell, and he ran so fast in pursuit that there was no escape from him; but he fell there-for such is the appearance of war. The musket is a bad weapon, the worst of all weapons; for let a man be as brave as he may, he cannot stand up before it long. Great chiefs are killed from a distance by no one knows who, and the strength of a warrior is useless against it.

As the soldiers chased Kawiti, the pa fired on them from the left, so that they had Kawiti in front and 
the pa on the left, both firing, and therefore lost many men; but having beaten Kawiiti off, they returned and took shelter in the Maori breastwork, and began again to fire at the pa. So they fired, and the pa returned the fire, and the main body of the soldiers who were at the front of the pa fired. Lead whistled through the air in all directions, the whole country seemed on fire, and brave men worked their work. Then Tupori, a chief who was in the pa with Heke, saw that Kawiti had elevated his name, for he had fought the soldiers hand to hand twice-once at Kororareka, and once on this day; and seeing this, Tupori wished also to do something to make his name heard; he therefore cried out for only twenty men to follow him, and he would charge the soldiers. Then twenty men rushed out of the pa with Tupori; they ran straight up the hill to the breastwork, the soldiers firing on them all the time, but without hitting one man. So Tupori and his twenty men came quite up to the breastwork, and stood upon the top of the bank, and fired their double-barrel guns in the soldiers' faces, and drove them out of the breastwork. The soldiers retreated a short distance, and Tupori and his people began collecting the bundles of cartridges which the soldiers had left behind; and while they were doing this, the soldiers suddenly came rushing upon them. Their charge was very grand, and terrible to look at. They came rushing on in great anger, shouting and cursing at the Maori. So Tupori and his men ran away to the pa, and as they ran the soldiers fired at their backs, and killed two 
men, and wounded Tupori in the leg. The rest got safe into the pa, and took Tupori and the two dead men along with them. Great is the courage of Tupori! he has made his name heard as that of a toa. But it was not right for the soldiers to curse the Maori, for up to this time nothing wrong had been done on either side, and so the Maori were much surprised to hear the soldiers cursing and swearing at them.

After this the soldiers fired at the pa all day, but only killed three men, besides the two men killed in the charge of Tupori; these five men were all killed belonging to the pa that day. When it was near night, the soldiers went back to Walker's camp at Okaihau, taking with them their wounded, and also two or three dead; but about ten dead were left behind at Taumata Tutu, where they fell in the fight with Kawiti.

So Heke remained in possession of the battle plain (te papa), and his pa was not taken, and he buried the dead of the soldiers. But one soldier who had been wounded, and left behind by the side of the lake, was found next morning by two slaves, and they pretended they were friends, and got his gun from him, and then they took him to the lake and held his head under water till he was dead.

Next morning after the battle the soldiers returned to the Keri Keri, and Walker went with his people to help them to carry the wounded. And Hauraki, the young chief of the Hikutu, went also with thirteen of his people to assist in carrying the wounded soldiers; 
but the rest of his tribe, being one hundred men, remained behind at Okaihau, for it was not expected there would be any more fighting for some days. But when the soldiers and Walker's people came to the Keri Keri, the Maori chiefs of Walker's party talked of attacking the Kapotai at Waikare, in the Bay of Islands, because they were allies of Kawiti; so they went and told their minds to the chiefs of the soldiers, who agreed to do so, for they were angry at not having been able to take Heke's pa at Taumata Tutu.

So when the soldiers and Walker's people came to the Bay of Islands, they each separated a party to attack the Kapotai. They went up the Waikare river in the night in canoes and boats, with great precaution, hoping to surprise the Kapotai, and so to revenge their dead who had fallen at Taumata Tutu; but before they got near to the pa, the wild ducks in the river started up and flew over the pa, which alarmed the Kapotai, and caused them to suspect that an enemy was coming up the river, so they took arms and watched for the approach of the war party. And soon the soldiers were near, but it was not yet daylight. Then the men of the Kapotai called out, "If you are Maori warriors who come in the night, come on, we will give you battle; but if you are soldiers, here is our pa, we give it you." They soon discorered the soldiers, and then they went out at the back of the pa, and left it for the soldiers to plunder, as payment for Kororareka, which was very right. So the soldiers and Walker's Maori plundered the pa of the Kapotai, and killed all the pigs. 
After the Kapotai pa had been plundered and burnt, Walker and his men went in pursuit of the Kapotai, who had retreated into the forest, but the soldiers remained behind on the clear ground near the pa. Walker, Mohi, and Repa went into the woods with three hundred men, followed the Kapotai, and overtook them. When the Kapotai perceived they were followed, their anger was very great, so they turned, and fought with great courage against Walker. Walker was not able to beat them, so they remained a long time fighting in the forest. But Hauraki, the young Hikutu chief, had, with his thirteen men, taken another path, and he met the young chief of the Kopatai, who had with him sixty men, and they were both young men and fighting for a name, so a desperate fight commenced. Hauraki and his thirteen men thought not of the light of the sun or the number of the enemy; their only thought was of war, and to elevate their names. It was a close fight, and whenever the rifle of Hauraki was heard a man fell, and soon he had killed or wounded several of the Kapotai, who began to fall back. Then Hauraki cried out to the retreating Kapotai, "Fly away on the wings of the wood-pigeon, and feed on the berries of the rood, for I have taken your land." Then a certain slave of the Kapotai said, "That is Hauraki, a very noble born man. He is a chief of Te Hikutu, and of Te Rarawa, and of Te Ngati Kuri." Now when Hari the young Kapotai chief heard this, he cried aloud to Hauraki, saying, "Swim you away on the backs of 
the fish of the sea, ${ }^{1}$ there is no land for you here." Then these two young warriors drew nearer to each other. Hauraki had just loaded his rifle, but the caps which he had were too small, and he was a long time trying to put on the cap. While he was doing this, Hari fired at him, and the ball struck him on the breast and passed out at his back; but so great was his strength and courage that he did not fall, but took another cap and fixed it, and then fired at the Kapotai chief, and the ball struck him on the side under the arm-pit, and went out at the other arm-pit. So Hari staggered and fell dead. When Hauraki saw this, he said, "I die not unrevenged," and then sank gently to the ground. His people then seeing this, two of them led him away towards the rear. The Kapotai also carried away their chief, and then, enraged at his ceath, rushed upon the Hikutu, who were now only eight in number, the rest haring been killed or wounded. These eight were tino tangata (practised warriors), but were too few in number, and had lost their chief; so when the Kapotai rushed upon them they lost heart and fled, and the Kapotai chased them, and soon the foremost of the flying Hikutu orertook Hauraki and the two men who were leading him off. Then Hauraki said, "Do not remain with me to die, but hide me in the fern and escape yourselves, and go to my relation Walker, and tell him to muster all his people, and come and carry me off." So they all

1 In allusion to the fact of the war party having come by water. 
pressed their noses to the nose of Hauraki, one after another. And tears fell fast, and the balls from the guns of the Kapotai whistled round their heads, so while some returned the fire of the enemy, others hid Hauraki in the long fern. When this was done, they all fled, and escaped with great difficulty; for while they were hiding Hauraki the Kapotai had surrounded them, and they would never have escaped at all but for the great courage of Kaipo and Te Pake, Hauraki's cousins, who broke through the Kapotai, and opened a way for the rest.

Now, when Hauraki's eight men got on the clear ground, they found that the soldiers were getting into the boats to go away, and Walker, Mohi, and Repa had just come out of the forest from fighting with the Kapotai, and Hauraki's cousins ran to Walker, and said "Our friend" is left behind wounded in the forest, and likely to be taken by the Kapotai." Then Walker was very much dismayed when he heard this, and he and Mohi ran to the chiefs of the soldiers and desired them to remain for a short time till he should rescue Hauraki, but the soldiers could not understand what Walker meant, for the speaker of Maori (the interpreter to the force) had already gone away in one of the boats, and there

1 The natives when speaking to each other seldom mention their chief except as "our friend," or, if he be an old man, as "our leader." Speaking to Europeans, however, they often say our rangatira, that having become the only word in use among the Europeans to signify the chief of a tribe, though it may also mean many other ranks, according as it is applied. 
was a great confusion, every one trying to get away, and Walker's men were also getting into their canoes and going away, and boats and canoes were running foul of each other, and the creek was choked with them. Then came the Kapotai in great force with their allies out of the forest, and commenced firing on the departing taua from a distance of about two hundred fathoms, so the soldiers and Walker got away and returned to Kororareka, and left Hauraki lying alone in the forest, for their bellies were full of fighting. So he lay there till midnight, and the night was cold and wet, and he kept continually thinking what a disgrace it would be to his family if he should be taken alive. ${ }^{1}$ And as he lay thus, he sa ${ }^{2}$ the spirit of the greatest warrior of all his ancestors, who said to him, "Arise! Shall my descendant be taken alive?" Then Hauraki said, "I am a mere man, not like unto my ancestors, half god

1 That weakness is crime with the natives is a fact, and in consequence the disgrace of being taken prisoner of war degrades a native as much as with us it would degrade a man to be convicted of felony. I have heard two natives quarrelling when one called the other "slave," because his great-grandfather had been once made prisoner of war. The other could not deny the traditional fact, and looked amazingly chop-fallen. He, howerer, tried to soften the blow by stating that even if his ancestor had been made prisoner, it was by a section of his own tribe, and consequently by his own relations he was defeated. Thus endeavouring to make a "family affair" of it.

2 Poor Hauraki was no doubt delirious from the effects of his wound, and no doubt thought he saw the vision he recounted when his people found him. 
and half man." Then the spirit said, "In the mind is the strength of the body. Arise!" So Hauraki arose, and travelled a long way in the night till he found a small canoe by the river side; then he pulled down the river towards the Bay of Islands till the canoe upset; then he swam on shore, and when he got to the shore he was almost dead; but near to where he landed was the house of a pakeha, and the mother of this pakeha was Hauraki's cousin, so that pakeha took him and concealed him in the house, and took care of him, and before the middle of the day a party of Walker's men arrived there in search of him. So they took him to the Bay of Islands, and the doctors of the soldiers did what they could to cure him, but without success. So his tribe, who had arrived at Okaihau, carried him home to his own place at Hokianga, where he died.

When Hauraki died, and his body lay at Wirinake to be seen for the last time by his relations, there was a great gathering of the Rarawa and Ngapuhi,

1 One of the ancestors of Hauraki, according to a tradition of the Rarawa, hearing, even in the Reinga (the Maori Hades), of the warlike renown of one of his sons, became jealous of his fame, and returned to this world. Emerging from amongst the waves at Ahipara, on the west coast, where his son lived, he challenged him to single combat. At the first onset the son had the worst. Then the father said, "Had you been equal to your ancestors I would have remained here as your companion in arms; but you are degenerate and a mere man. I return to the Reinga, to be with the heroes of the olden time." He then disappeared in the waves. 
to fulfil the last rights due to a chief. And when the pite had been sung, ${ }^{1}$ then the chiefs arose one after another to speak in praise of the dead. This was the speech of Te Anu, he who is known as haring. been in his youth the best spearman of all the Ngapuhi tribes. Bounding too and fro before the corpse, with his famous spear in hand, he spoke as follows: "Farewell, Hauraki! go, taking with you your kincness and hospitality, your generosity and valour, and leave none behind who can fill your place. Your death was noble; you revenged yourself with your own hand; you saved yourself without the help of any man. Your life was short; but so it is with heroes. Farewell, O Hauraki, farewell." At this time it was night, and the sister and also the young wife of Hauraki went in the dark and sat beside the river. They sat weeping silently, and spinning a cord wherewith to strangle themselves. The flax was wet with their tears. And as they did this the moon arose. So when the sister of Hauraki saw the rising moon, she broke silence, and lamented

1 The pithe is a funeral chant sung standing before the dead. It is a very curious composition, and of great antiquity, having been composed long before the natires came to this country. Part of the language is obsolcte. It has allusions which point in a remarkable manner to the origin of the natives, and from whence they have come. They do not themselves understand these allusions, but they are clear enough to any person who has taken the trouble to trace the race from which they are derived through the Pacific Islands, far into north latitude, next into Asia, and to obserre the gradual modifications of language and tradition occasioned by time and change of abode. 
aloud, and this was her lament-the part I remember of it:-

It is well with thee, $\mathrm{O}$ moon! You return from death, Spreading your light on the little waves. Men say, "Behold the moon re-appears;"

But the dead of this world return no more.

Grief and pain spring up in my heart as from a fountain.

I hasten to death for relief.

$\mathrm{Oh}$, that I might eat those numerous soothsayers

Who could not foretell his death.

Oh, that I might eat the Governor,

For his was the war!

At this time men came who were in search of these women, and prevented the sister of Hauraki from killing herself at that time. They watched her for several days, but she died of grief. But the wife of Hauraki consented to live that she might rear her son, so that he might fight with the Kapotai on a future day. So she called his name Maiki, which is the name of the hill on which stood the flagstaff, the cutting down of which was the cause of the war. $\mathrm{He}$ was, therefore, called by this name, that he might always be reminded of his father's death.

The lament of the sister of Hauraki was sung by all the divisions of all the Ngapuhi, from the west coast to Tokerau. And when Walker heard it he was displeased, and said, "It is wrong to sing about eating the Governor, for soon people who do not know the song well will make mistakes, and sing, ' Oh, that I might eat Heke,' which would be the worst of all. As for the priests or soothsayers, it is no matter; they are all a set of fools." So now 
when people sing that lament, they only say, "Oh, that I might eat the numerous priests" (tini tohunga).

So Hauraki was taken to Te Ramaroa, a cave in the mountains, behind Wirinake, where his ancestors are buried, and then three hundred men of Te Hikutu, Natikuri, Te Rarawa, and Walker's people armed, and entered the country of the Kapotai, to fire powder in remembrance of Hauraki ${ }^{1}$ (paura mamae.) They destroyed the cultivations, and got much plunder; but the Kapotai retired to the forest, and would not fight, for they knew this was a war party of the tribe of Hauraki, who came bearing the weapons of grief (patu mamae), and, therefore, they would not fight. So the taua came to the spot where Hauraki had fallen, and there fired many volleys of musketry in honour of the dead, and then returned unmolested to their own country. The behariour of the Kapotai in this matter was correct. We all know that it was not fear that prevented them from attacking us; they respected the grief of the people and relations of Hauraki, and made way before them, which was a noble thought (whakaaro rangatira).

1 It is a native custom, when any chief of importance has been killed in fair fight, for his friends to form a party and enter even the enemy's country, should he have fallen there, and fire some volleys in his honour on the spot where he fell. This they call paura mamae-powder of pain or grief. They, of course, do it at the risk of being attacked, but the natives often allow the custom to be fulfilled without molesting the party, although a party of this kind always plunder and ravage all before them. 
When Heke heard of the death of Hauraki, he said, "Now, if I am slain in this war, it matters not, for there is no greater Ngapuhi Chief than Hauraki." What Heke said was true; but he said it to please Te Hikutu, for Heke is a man of many thoughts.

At this same time, Te Tao Nui, who was at Okaihau, heard that most of Heke's men had gone from Te Ahuahu to Ohaeawae to kill cattle for food; for by this time Heke had abandoned his pa, near Taumata Tutu, which the soldiers had attacked, and gone to another fort of his at Te Ahuahu, to be near the cultivations. So Te Tao Nui took sixty men, and went on a dark rainy night and took the pa at the Ahuahu by surprise, and the people in it only fired two shots and fled. So Te Tao Nui remained in possession of Heke's fort at the Ahuahu, and all Heke's provision fell into his hands, and also the road to Ohaeawae was opened, for this fort was on the path. Then Walker abandoned his camp at Okaihau and joined Te Tao Nui in Heke's pa, and as they found there plenty of provisions, they determined to remain there till the soldiers should return again from Auckland.

But Heke was very much enraged to see his fort and provisions thus snatched from him, and he determined to retake it before the soldiers should return from Auckland to help Walker. So he sent messengers to all parts of the country where he had friends, and to the old chiefs who were still alive who had been companions of the great Hongi in the old wars. 
And they came, and with them came Te Kahakaha, he who had been Hongi's chosen friend. He had seen more battles than any man now alive, and was a very brave and experienced leader. He came to assist Heke, and to show him how his fathers had fought.

When Heke's war party had assembled, they were, in number, about eight hundred men; and, after having rested a few days at Ohaeawae, they marched before daylight to attack Walker and Te Tao Nui at Te Ahuahu, and to retake Heke's pa. Walker, Tao Nui, Moses, and Wi Repa, with his two brothers, were the principal chiefs of Walker's party at this time, and they had with them only about three hundred men, for many of Walker's friends had returned to Hokianga, to fetch pork and other provisions, for they did not expect to be attacked so soon.

Now in the morning before daylight, an old slave woman went out from the pa of Walker to pick up sticks for firewood. And there was a thick fog lying close to the ground; and before the old woman had gone far she saw a black line of something coming out of a cloud of fog, and as she was wondering what this might be, she suddenly perceived that it was a taua of armed men, and they had got within fifty fathoms of the pa, ${ }^{1}$ so she cried aloud the cry of alarm-Te Whakaariki e! Te Whakaariki e!-and

1 The natives estimate distances by fathoms and tens of fathoms. A liume is ten fathoms. 
instantly the people in the pa were alarmed, started from sleep, and with their arms in their hands rushed hurriedly to defend the gates. Then Walker called out to Te Tao Nui, "Remain you here and defend our pa, and I will go out and fight." Then Walker and his people rushed against the enemy. And when they were doing this, another party of the enemy appeared at the opposite side of the pa. Of this party the old chief Te Kahakaha was the leader. Then, when Te Tao Nui saw this division and their numbers, which were great, he said- "Now we have the enemy in full view; there are no more of them in concealment." So he opened the gates on his side of the pa, and rushed out with his people, and called out to charge. So Walker charged at one side of the pa, and Tao Nui and his people on the other. Walker being opposed to Heke, and Tao Nui to Te Kahakaha, the fight began, and this was the greatest battle in the war. The best men of both parties were there, and Heke was very desirous to destroy Walker in one great fight before the soldiers should return; and Walker, on his side, wished to show that he could fight Heke without the aid of the soldiers. So now Walker charged Heke, and Heke fired like thunder against Walker. I, your friend, was there! and as we rushed on, Karere Horo was killed (he was our mad priest); and Taketu was killed, and Te Turi, and Hangarau, and about nine others; and Takare had both his eyes shot out, and Wi Repa and his brother, and Hakaraia, the chief of the Ngati Pou, and a great many others, were wounded. By the 
time all these people were killed or wounded, we were close up to Heke's people, and began to fire. Heke's men being so near, and standing too close together, we did not miss them; we had revenge for our friends who had fallen. We pressed Heke hard. Not one of us remembered the light of this world, nor thought of life. Then the enemy began to fall back, and we followed them close till we came to a hill side, where they turned and charged us. But we fell back a little then, and got behind the stone wall of a kumera field, and fired at them from behind the low wall, and drove them back, having killed and wounded several. They then returned to the hillside, and began firing at us from about fifty fathoms' distance; but we were sheltered by the low stone wall. Then we heard Heke shouting out to charge us again, and so down they came upon us again. They greatly outnumbered us, and the sound of their feet as they rushed on was like the noise of a waterfall. We fully expected this time they would finish us, but Walker cried out, "Stand firm! let them come close; waste no powder." So we stood firm, and took aim over the stone fence, and let them come so close that the smoke of our guns would pass by their foremost men. Then we fired, and some of our toa jumped over the wall and ran at them with the tomahark, upon which they fled away to the hillside again, leaving their dead and wounded in our hands. Then some of our young men, being hot with the fight, cried out to eat them raw at once; but this was a foolish proposal, for although we were 
fighting against Heke, we were all Ngapuhi together, and more or less related to each other. Had we been fighting Waikato or Ngatiawa of the south, it would have been quite correct. So Walker and the other chiefs would not allow it.

While this was going on on Walker's side, Te Tao Nui and his family were fighting against the division of Te Kahakaha and the Wharepapa at the other side of the pa; but Te Kahakaha knew by the sound of the firing that Heke had lost ground and was falling back, so he fell back also slowly, intending to join the right of his division to Heke's left, so as to fill up the opening which had been made by Heke falling back, and then to renew the battle. But, in falling back, his men lost heart, and Te Tao Nui pressed him hard; so, to encourage his men, he adranced to the front, calling loudly, "Whatahokai!" and, as he ran forward, his men followed. He was quite naked, and only armed with a light spear. He came on lightly, like a young man, seeking a man for his spear; and he rushed upon one of the warriors of the Ngati Pou, but before he got close enough to strike, a shot struck him on the breast, and came out at his back, which turned him quite round. Then another shot struck him on the back, and went out at his breast. Then he sank to the ground, saying"Fight bravely, O my family and friends! for this is my last battle." So he lay quiet there, but did not immediately die, for he lingered to see once more the young man Heke, who was the representative of Hongi, his old companion in many wars. 
When Te Kahakaha had fallen, the battle would have been quickly lost but for the Wharepapa, the old chief of the Ihutai. He was a brave old warrior, and had also fought in the wars of Hongi Ika. He came forward laughing, and calling on his tribe to stand firm, for he wanted to save the body of $\mathrm{Te}$ Kahakaha. So the Ihutai stood firm, and for a time the fight became stationary in that place.

At this moment a boy came running to Heke, where he stood opposed to Walker on the extreme right of the battle. The boy ran up to Heke and cried, "The old man has fallen." Then Heke said, "What old man?" The boy answered, "Te Kahakaha." Then Heke said, "Is he quite dead ?" and the boy answered again, and said, "He is quite dead, and the people are falling back, and his body will be taken by the enemy." When Heke heard this his heart rolled about in the hollow of his breast. He threw away his cloak and gun, and ran naked and unarmed all along the front of the battle until he came to the place where the old man was lying. And here he met many men who were running away, and he quickly drove them back to the fight, for they were terrified by his look-his appearance was hardly that of a man. Then he came to where the old man lay, and having knelt down, pressed his nose to the nose of the dying man, and said, "Father, are you slain ?" And the old man said, "Son, I am slain; but in whose battle should I die if not in yours? It is good that I should die thus." Then Heke ran amongst the people and called out to charge; but 
many had fled. The tribe of Ihutai alone remained, and some few others. They, however, charged desperately, and drove back Te Tao Nui a short distance. Then Heke tore a cartridge-box from the body of a dead man, and cried out to the Ihutai to hold back the enemy a short time while he should get away the body of the old man. Then he ran away to where he had seen Te Atua Wera standing on the path trying to rally those who were flying, and to collect them on that spot to fight again. This Atua Wera, you already have heard, is the wisest priest and prophet of all the Ngapuhi, and he stood there in the path stopping the flying people with his club. But who can bind a flowing river? Tall men with long tattooed faces ran by like a stream, and were deaf to his call, but he had about twenty men who stood firm. Then Heke came running up and cried out, "Advance at once and carry off the old man while it can be done." Then Te Atua Wera said, "Give me a gun and some cartridges; I have only a club." Then Heke held out the cartridge-box, and said, "Take a gun from one of the people," and being mad with haste, and rage, and grief, he began to buckle the cartridge-box round the waist of the priest. But Te Atua Wera perceived that there was blood on the cartridge-box, so he started back and said, "Where did you get this?" Then Heke cried out, "Where should I get it? is not this war?" So then the priest saw that Heke himself, the chief of the war, had been the first himself to transgress the sacred rules, and had touched 
the bloody spoils of the slain. So he said to Heke, "The Maori Atua are arrayed against us, the spirits of the dead are now angry; we are lost; and you, Heke, are now no longer invulnerable. ${ }^{1}$ Go not to the front, or you will meet with misfortune. Leave the old man where he is, it cannot now be helped; " and having said this, Te Atua Wera took the cartridgebox on the end of his club, and threw it away, club and all, into the high fern. ${ }^{2}$ Then Heke roared out, "What care I for either men or spirits? I fear not. Let the fellow in heaven look to it. Have I not prayed to him for years? It is for him to look to me this day. ${ }^{3}$ I will carry off the old man alone."

1 The priest had promised Hele that he should be himself personally invulnerable so long as the old superstitious war customs were observed, but which Heke had in this instance broken.

2 This whole scene between Heke and Te Atua Wera is described exactly as it occurred. I have heard it described by several eye-witnesses, one of whom was the Atua Wera himself, and they all gave the same account. The native priests prescribe many rules and observances to the people, and prophecy good fortune, provided none of these rules be broken, well knowing that some of them will to a certainty be broken by the careless and incorrigible Maori. In case of the failure of any of their predictions, they have the excuse that some sacred rule had been broken. In this particular instance the Atua Wera, secing the battle going against Heke, took advantage of his having handled the bloody cartridge-box; the people having been forbidden to touch anything having the blood of the enemy on it, until certain ceremonies of purification had been performed after the battle, to render plunder or spoil lawfully tangible.

3 Heke had been for years a Christian, according to the Maori notion of Christianity, which was then, if not now, a mere jumble 
And Heke's eyes rolled towards heaven, and he ground his teeth. Then he ran forward to carry off Te Kahakaha, but ten of the men who were with Te Atua Wera followed him, for they were ashamed to see the chief go alone and unarmed to carry off his ancient friend, but Te Atua Wera remained where he was.

All this which I have told took but little time, for in battle when men's eyes shine there is no listlessness. But by this time Heke's men to the right were quite defeated by Walker, and running away; but Waker pursued them slowly and with caution, for the ground was covered with brushwood, and rocks, and high fern, and the enemy though defeated were

of superstition and native barbarism. Here Heke says, that because he prayed to the "fellow in heaven"-by which he means that at stated periods he had for some years made use of certain words which were supposed to gain the favour of "the European God"-that in consequence that God should favour him now if he was able. The word karalia which Heke made use of does not mean prayer as we understand that word. $K a$ rakia properly signifies a formula of words or incantation, which words are supposed to contain a power, and to have a positive effect on the spirit to whom they are addressed, totally irrespective of the conduct or actions, good or bad, of the person using them. The fact is that the Maori has, perhaps, the lowest religious character of any human being; his mental formation seems to have the minimum of religious tendency. The idea of a supreme being has never occurred to him, and the word which the missionaries use for God (Atua) means indifferently, a dead body, a sickness, a ghost, or a malevolent spirit. Maui, the Atua, who they say fished up the island from the sea, is supposed to have died long ago by some, and all agree that he no longer exists. 
still more numerous than we were, and we followed slowly lest we might fall into an ambush.

So Te Atua Wera sat on a stone beside the path waiting for the return of Hele, and soon he saw that the battle was lost, for people came running past in great numbers, and among them came the men who had gone with Heke, and they brought with them the body of the old man, Te Kahakaha, which Heke had gone with them to bring away. The fire of Te Tao Nui now began to come closer, and the bullets were cutting down the fern all round them, and the Atua cried out to the bearers of the body to inquire for Heke, and they said he was close behind them. So Te Atua waited some time longer, but Heke did not come, and the enemy were getting near, and his mind was disturbed, for he had a presentiment of evil. At this moment Hoao, a very noted Ngapuhi warrior, came jumping over the fern, and seeing the Atua Wera, he shouted, "Turn-face the enemy, for Heke has fallen, and unless quickly rescued will be taken." Te Atua said, "Where is he?" The man said, "Here in the hollow, where I have hid him in the high fern, but could not carry him off myself." Te Tao Nui had now got close, and some of his men had actually passed where Heke lay, but had not discovered him. So now Te Atua Wera saw it was his time to do his part, so he called out "Come, follow me to die for Pokaia." Three men started for-

1 In the agitation caused by hearing that Heke had fallen, the Atua Wera called Heke by the name of Pokaia. This was the 
ward at this call; they ran to where Heke was, and bore him off. In doing so they were more than once surrounded by the enemy, but the fern and brushwood were so thick that they got off unperceived. The fern and brushwood would not, however, have saved them had it not been for the Atua Wera, who, by his continual larakia (incantations) rendered the bearers of Heke invisible to the enemy. The three men who carried off Heke were all from Hokianga; they were all elderly men, and practised warriors. Their names were Ta Pura, Hoao, and Te Ngawe.

So Heke lost in this battle many of his best old war chiefs, he was himself badly wounded and defeated, and escaped with difficulty to the fort at Ohaeawae, to which place he was chased by Walker and Te Tao Nui. These misfortunes would not have happened had not Heke been so thoughtless as to handle the bloody spoils of the dead, before the proper ceremonies had rendered them common. But there is nothing in this world so deaf to reason or so disobedient as a warrior-when he is enraged he only listens to his own courage, and, being led away by it, dies.

After this battle Heke remained some time at Ohaeawae, and Walker stayed at Te Ahuahu, the

name of Heke's father, a celebrated cannibal warrior and desperate savage. His closing scene took place in the country of the Ngatiwhatua, where, having gone in a war expedition, he and his 300 men were killed and eaten, almost to a man, by the Ngatiwhatua, who in their turn were all but exterminated by Hongi Ika in revenge for Pokaia. 
fort which Te Tao Nui had taken. Walker buried Heke's dead which had been left on the field, and there was a great lamentation at both forts, for the number of killed on both sides was great.

Heke, and Kamiti, who had again joined him, now enlarged, and strengthened, and completely finished the pa at Ohaeamae, where they were stopping. It was originally but small, and belonged to Pene Taui, but they now completely finished it, and made it a perfect Maori fort in erery respect. The inside fence was made of a very hard wood which does not splinter much; the posts of this fence were about one fathom in the ground, and the fence over ground was about four fathoms high. The posts were stout, and some of them would require thirty men with ropes to raise them. Inside this fence was the trench in which the men stood to fire; their faces only reached the level of the ground outside the fort. The loop-holes, through which the men fired, were also only level with the ground outside, so that in firing the men were very slightly exposed. Outside of all was the pekerangi, which is a lighter sort of fence put up to deaden the force of shot before it strikes the inner one, and also intended to delay a storming party, so that while they would be pulling it down, the men behind the inner fence might have time to shoot them. This pekerangi was nearly as high as the inner fence, and stood little more than half a fathom outside of it; it was made of a strong framework, and was padded thickly with green flax to deaden the force of shot. It was also elevated about a foot from 
the ground, so that the men behind the inner fence, standing in the ditch, could shoot through the loopholes in the inner fence under this outside fence; also at different distances along the kaue (curtain) there were koki (flanking) angles, capable of containing many men, so that a storming party would be exposed to a fire both in front and flank, and in these angles were put large ship guns. The men inside, in the inner trench, were also protected from a flanking fire by pakeaka (traverses), which crossed the trench at intervals; also inside the place were many excavations under ground covered over with large $\log$ s of timber, and over the timber earth. In these pits the men could sleep safe from the shot of the big guns of the soldiers. There were also high platforms at the corners of the inner fence, from whence could be seen all that an enemy might be doing outside.

When this fort was completely finished and provisioned, the priests (tohunga) took, according to ancient custom, the chips of the posts, and with them performed the usual ceremonies, and when they had done so they declared that this would be a fortunate fortress; so it was made sacred (tapu,) as were all the men who were to defend it.

This fortress being now quite finished and ready for war, the soldiers came from Auckland to attack it, and also came the sailors and Pakeha Maori (Militia). They landed at the Bay of Islands, came up the Keri Keri in boats, and from thence to the Waimate along the cart road. They brought 
with them two very small brass guns, and two very short iron ones (mortars). The short iron guns looked like potato pots, and we laughed at them, and thought of Heke's saying of "What prize can be won by such a gun?" We however, notwithstanding our laughing, thought they must have some use, or the soldiers would not have brought them.

At last, after remaining several days at the Waimate, the taua advanced against Ohaeamae. The soldiers, sailors, and other pakeha might be in number about eight hundred, and we Maori were four hundred. The enemy did not attempt to oppose our advance, which was very good; for the soldiers were so heary loaded with cloths, and tied up with belts, and had such heary cartridge-boxes and also little water casks, hanging to their sides, and packs on their backs, besides the musket and bayonet, that we all said that if we Maori were loaded in that way, we should neither be able to fight nor to run away. Great is the patience of the soldiers!

At this time Heke was very ill, and expected to die from his wound which he had received at the great fight at Te Whatuteri. So his people took him away to his own place at Tautora, and Te Atua Wera and sixty men remained there with him. Many, also, of the men who had been at the fight with Walker at Te Whatuteri had returned home, so there remained at the pa at Ohaeawae only Kawiti, Pene Taui, and one hundred men.

So the soldiers encamped before the pa at the distance of about two hundred fathoms. There was 
a little hill on their right, rather advanced towards the pa. Walker took possession of this hill, and encamped upon it with about sixty men. This hill overlooked both the pa and the camp of the soldiers, and from it everything could be seen that was going on. The rest of the Maori encamped at a short distance behind the soldiers; and on the left of the soldiers, and a little advanced, were placed the four little big guns, two of brass and two of iron.

So now both parties being face to face and close to each other, they were very watchful. Some of the soldiers stood all night watching between the camp and the pa, and the people in the pa watched also, and the watch-cry resounded among the hills. This was the cry of the pa: "Come on, soldiers, for revenge; come on! Stiff your dead are lying on Taumata tutu. Come on! Come on!" 1 Then in answer was heard the watch-cry of Walker: "Come on, O Ngapuhi, for your revenge, come on! We have slain you in heaps on the battle-field. Come on! Come on!" So passed the first night before Ohaeawae.

Next morning the four little big guns began to fire at the pa, but they did no damage. Some of the shots stuck fast in the large posts, but did not go through; others went between the posts, making a mark on each side, but leaving the posts standing as strong as ever. As for the men in the pa, they

1 "Whai mai e te hoia, ki tetahi utu maua akato wharoro ana koe, kei Taumata tutu-whai mai! whai mai!-The watch-cry. 
were all in the trenches, and the shots which came through the fence went over their heads, and did them no harm. After the guns had fired a few times, the people in the pa began firing at them with muskets, and soon killed one sailor, and wounded some others. So the men left the guns for the rest of that day, but in the night they took them away, and placed two of them on the hill where Walker had encamped, and the other two on the level ground between that hill and the soldiers' camp. They also made banks of earth to shelter them, so that the men who fired them were safer than they had been the day before, when they had only a little green flax to cover them, which was of no use.

Next day the guns began to fire again, and continued until night; and also a great number of soldiers, sailors, and Maori scattered themselves about the pa, and fired at it with muskets, but could do no harm; and this went on for several days, but the fences of the pa remained standing, and not much injured. I think, however, that although the guns were smaller than they should have been, if they had been continually fired at one place, an opening in the fence would have been made at last; but instead of doing this, when they had been fired for half a day at one part of the fence, then the soldiers would begin firing at some other part of the pa, and then the people would come out of the trenches and repair any damage which had been done at the place at which the guns had been fired at first. We Maori did not think the soldiers did wisely in this respect, 
but they may have had some reason for it which we could not understand, for we don't know much about big guns; as was also seen at Ohaeawae, for there were four big guns in the pa, larger than those of the soldiers, and they were fired at us very often, but they never hit any one. My idea is, that big guns are no use to knock down a pa, unless they are very big indeed. But the Maori say that in future wars they will build forts where it will be hard, and take a long time, to bring big guns; and when the soldiers after much pains get them there, they will leave the pa at once, and go somewhere else where it will take a long time to follow them, and so on till the soldiers are tired of dragging big guns about the country, after which both parties will be armed with muskets only, and the Maori can use these arms as well as the soldiers. This is what I have heard say, and I think it a very correct thought.

So the firing of big guns and muskets went on day after day, but no opening was made in the face of the pa; but the chief of the soldiers ${ }^{1}$ did not care much for this, for he wanted every day to send his men to rush up to the pa, to pull down the fence with their hands, or pull it down with ropes, and so get in. But Walker and the other chiefs always prevented this, as they knew that all the soldiers would be killed before they could get in in this way. Every one of the Maori were of this opinion, and also some of our old pakeha friends who were with

1 Colonel Despard. 
us, and who knew the appearance of the Maori in war. Nevertheless, the chief of the soldiers wished every day to send his men to rush up to the pa; and so, at last, we heard so much of this that we began to be very melancholy, and Walker told me that he felt sick in the stomach when the chief of the soldiers spoke to him about it, it seemed so great a waste of men's lives. We all became, as I have said, very melancholy, for we all began to see that it would be done at last, and we grieved, therefore, for our friends the soldiers, who we knew would be all killed. But what vexed us most was, that so fine a war party as ours should be beaten by such a small number of people as were in the pa, only because the chief of the soldiers was a foolish, inexperienced person. ${ }^{1}$

At last the chief of the soldiers thought of sending for a very large gun from a ship of war at the Bay of Islands, which would be large enough to break down the fence. If he had done this at first an opening would soon hare been made, and the fort taken without many men being killed; but as it was, this gun when it came was of no use, for the chief of the soldiers did not wait till it had broken down the fence, but attempted to take the pa without this having been done.

This gun was placed at the foot of the hill where

1 The pa at Ohaeawae was attacked against the advice of the fricndly native chiefs, who well knew its strength, and the certain repulse to be expected. They called Colonel Despard anything but a soldier, and the term "foolish and inexperienced" is the mildest they applied to him. 
Walker had his camp, and it was not fired many times before it became apparent that should it keep on firing till next evening, a large opening would be made in the fence; so we began to think that the chief of the soldiers would have patience, and wait till this should be done.

Now on this same day, when this big gun began to fire, thirty men came out of the pa unperceived, and coming through a wood in the rear of Walker's camp, at a time when Walker and most of his men were absent, they rushed in and plundered it, killing one soldier who was there, and also one Maori, and wounded also a pakeha, the son of a missionary. They pulled down Walker's flag and took it away, and having fired a volley at the camp of the soldiers, ran off to their pa, leaving one man killed, who was killed by Tara Patiki, and not by the soldiers, as I have heard say. I am sure of this, for I saw Tara Patiki shoot him. They were close upon us before we saw them, and we had great difficulty to escape, but we both jumped into the fern, and ran down the hill as hard as we could. I fired my gun right into the middle of them, but as only one man was killed, I suppose my shot missed.

When the soldiers saw that Walker's pa was taken, they came out of their camp, and charged up the hill; but when they came to the top, they found that the enemy were gone, and had taken away everything valuable they could find; they found the soldier who had been killed. He had been sent there by the chief of the soldiers to take care of one of the little 
big guns which had been removed up to that place, so he was killed there; but I have heard that the chief of the solciers when he wrote his letter to Auckland, to tell the Gorernor about this matter, said that this soldier was killed in charging up the hill; but this is not true, for I and many others got to the top of the hill before the soldiers, and when we got there the enemy were gone, and the dead soldier was lying there where he had been killed, close to the small big gun.

This affair, however, made the chief of the soldiers quite mad, so that same evening he ordered all his men to rush upon the pa and pull it down with ropes, or climb orer it with ladders, or any way they could; he also sent to Walker to tell him what he was about to do. Walker spoke against it, as he had done before, and adrised to wait one day more, till the big gun had made an opening for the soldiers to rush through quickly; otherwise, he said they would be all killed, and not get in at all. But the chief of the soldiers would not wait. So when Walker saw the attack would be made he offered to attack also at another face of the pa, and also twenty young men, cousins of Hauraki, the young chief of Te Hikutu, who was killed at Waikare, came and asked leare to go with the soldiers; but the chief of the soldiers would not let them go; neither would he consent to Walker's maling an attack, lest meeting the soldiers in the pa, his men might be mistaken for the enemy.

When we saw that the attack was determined upon, and just going to take place, we were all in a great 
state of agitation, and knew not what to think. Most said all the soldiers would be killed; but then we thought, on the other hand, that perhaps these European warriors could do things above the understanding of us Maori, and so perhaps they might take the pa. But all thought the chief of the soldiers very wrong to attempt the thing before an opening had been made for the soldiers to enter by. Also, Toby (Lieutenant Philpots), who was chief of the sailors, and a very brave gentleman, had walked close up to the fence of the pa, and along it, and, after having examined it, he returned, and told the chief of the soldiers that the place could not be taken by storm, unless it was first breached. When Lieutenant Philpots went up to the pa, the people were firing at every one who showed himself, and at first they fired at him; but he walked straight on, not caring about the shots which were fired at him. So, when the people in the pa saw that it was Philpots who had done this, they ceased firing at him, and told him to go back, as they did not wish to hurt him. So having examined the fence closely, he returned, but the soldier chief did not mind what he said, and was angry, and spoke rudely to him for having giren his opinion on the matter.

So now the chief of the soldiers mustered his men and divided them into parties. One party he stationed on the hill which was Walker's camp, and with all the rest he went to the attack. And first came a small party with a young chief leading them; these were all toa who had consented to die, so that those 
who followed might succeed. After them came a party of about eighty men, and after these came the main body of the soldiers; and with them also adranced the sailors, and the pakeha Maori, carrying ladders. The sailors advanced without their chief, for as yet he (Philpots) remained to fire some last shots from the big gun. But there was with them a young chief called Pena (Mr. Spain). So the whole attack moved on. We soon saw with great surprise that the soldiers were not going to attack that part of the pa which for so many days had been battered by the big guns, and where there might have been some small chance of their getting in, for in that direction the fence had been damaged in some degree, particularly by the large ship gun. The soldiers, howerer, advanced as they had been ordered against that part of the pa which had been built stronger than. any other, and which had not been fired at at all by the big guns. The reason why this part of the pa was the strongest was, because it was the part which had been originally built by Pene Taui as a pa for himself. He had begun it at the beginning of the war, and built it at his leisure, and made it very strong. And also that part of the pa was the nearest to the forest; so all the largest and heariest timber, which was difficult to move, was put there. But when Heke and Kawiti fell back to Ohaeawae, this original pa was found too small to hold their people; so they enlarged it very much; but, being in a great hurry, expecting the soldiers back from Auckland, they could not take time to make the new part so 
strong as that which had been first built by Taui; but, nevertheless, by working hard day and night, they made it very strong.

So the soldiers marched on silently and in good order, in full view of the pa, till they came opposite to the part they were about to attack, and then they halted in a little hollow to prepare for the great rush. But all this was done quietly, and in an orderly manner. The chiefs did not make speeches, or jump, or stamp about as we Maori do to encourage the men, but all was quiet, and silent, and orderly, as if nothing uncommon was about to take place. I took great notice of this, and did not know what to think; for, when we Maori have determined to do a desperate thing like this, we are all like mad men, and make a great clamour, rushing towards the world of darkness (te po) with great noise and fury.

While the soldiers were advancing, Walker and all the people went and took up a position behind the pa, so that in case the soldiers got in, the retreat of the enemy would be cut off, in case they attempted to escape in that direction.

Now the defenders of the pa perceived that the time of battle was come, and all went to their stations, and the chiefs stood up and made speeches, each to his own family. This was the speech of Haupokeha-" Have great patience this day, O children and friends; we have said 'Let us fight the soldiers,' and behold the rage of the soldier is at hand; be brave and enduring this day; be victorious; the parent who maintains us is the land- 
die for the land!-die for the land!" Other chiefs spoke to the people, and some of the young men left the trenches, and called to the old men to lead them out to fight the soldiers in the open plain before the pa; but Haupokeha, in great anger, said, "No; this shall not be done : return to your stations, and you shall see the enemy walk alive into the oven: they are coming only to their own destruction." At this moment the bugle sounded, and the soldiers came charging on, shouting after the manner of European warriors, and those who were on Walker's hill shouted also; and we Maori behind the pa shouted also; and the whole valley resounded with the anger of the pakeha! Soon the soldiers were within twenty fathoms of the fort; and then the fire darted from under the pekerangi; the noise of guns was heard, and the foremost soldiers fell headlong to the ground. But the soldiers are very brave: they charged right on, and came up to the pekerangi, which is the outer fence, and began to tear it to pieces with their hands. Then Philpots, when he saw the sailors charge, left the big gun and ran across the plain, and joined them; and he, being a toa, shouted to his men to be resolute, and destroy the fence; and then, with one pull, the sailors brought down about five fathoms of the pekerangi; and then they were before the true fence, which being made of whole trees placed upright and fixed deeply in the ground, could not be pulled down at all. All this time the fire from inside through the loopholes continued unceasingly, 
at the distance of one arm's length from where the soldiers were standing, and also a heavy fire came from a flanking angle at a distance of ten fathoms; and in this angle there was a big gun; it was heavily loaded with powder, and for shot there was put into it a long bullock chain, and this was fired into the midst of the soldiers, doing great damage. So the soldiers fell there, one on the other, in great numbers; but not one thought of running away. And Philpots did all a man could do to break down the inside fence, but it could not be done at all; so he ran along this fence till he saw a small opening which had been made to fire a big gun through, and he tried to get through this opening, at the same time calling to his men to follow. Then the people in the pa saw him, and about ten men fired at him, but all missed, and he almost got into the midst of the place, still calling on his men to follow, when a young lad fired at him, and killed him dead at once. So he lay there dead with his sword in his hand, like a toa as he was; but the noise and smoke, shouting and confusion, were so great as to prevent his men from perceiving that he was killed, and bearing off his body, for such is the appearance of war. Also, a chief of the soldiers was killed (Captain Grant), and another died of his wounds, and there was a long line of dead and wounded men lying along the outside of the fence, and soon all would have been killed, but the chief of the soldiers, seeing this, sounded a call on the tetere (bugle) for them to retreat. And then, but not before, the 
soldiers began to run back, taking with them most of the wounded; but about forty dead were left behind, under the wall of the pa. This battle did not take up near so long a time as I am telling of it, and in it about one hundred and ten Europeans were killed or wounded.

Great is the courage of the soldiers! They will walk quietly at the command of their chiefs to certain death; there is no people to be compared to them; but they were obliged to retreat. The number of men in the fort was about one hundred and serenty, and the part attacked was defended by the hapu of Pene Taui, in number just forty men. So the war runners ran through all the north, saying-" One wing of England is broken, and hangs dangling on the ground."

Before saying any more of this fight, I must tell you of two slaves-one called Peter, who belonged to Kaetoke, and the other called Tarata, who belongs to Ti Kahuka. Many years ago Tarata went to England in a large ship, and having gone ashore to see what he could see, he lost his way in the great town called London. So, in the night, the police found him wandering about, and took him prisoner, and put him in the whareherehere (watch-house), for they thought he had stolen a bundle of clothes which he was carrying. In the morning they brought him before the chief and accused him, but Tarata had not been able to learn to speak English, so he could not defend himself, or say from whence he came; so he thought he was going to be killed, 
and began to cry. Just then a ship captain came into the house, and seeing Tarata he knew he was a Maori, and spoke to him in Maori, and told him not to be afraid, and then he turned to the chief of the police and made a speech to him, and to all the people who were assembled there to see Tarata killed, as he believed; but when the ship captain had done speaking, the chief of the police was no longer angry, and said, "Poor fellow, poor fellow;" and then all the people present gave each a small piece of money to Tarata. Some gave sixpence, some a shilling, and some a few coppers; the chief of the police gave Tarata five shillings. When all the money was together there was more than ever Tarata had seen before, so he was very glad indeed; and a policeman went with him and showed him the way to his ship, and took care of him, lest he should be robbed of his money. After this Tarata returned to New Zealand, and many years after he came with his chief to the war to help Walker. So at Ohaeawae, when he saw the soldiers going to the attack, he thought of the goodness of the people of England, and so he said, "I will go and die along with these soldiers." Then, when Peter, the slave of Kaetoke, heard this, he said, "I also am a pakeha; I have been reared since a child by the Europeans; they have made me a man, and all the flesh on my bones belongs to them." So these two slaves ran quickly and took their place with the wakaka (forlorn-hope, or leading party) of the soldiers, but when the chief of that party saw them, he ordered 
them to return; but they persisted in going on, so the soldier ran at them and cut at them with his sword, and his soldiers were shouting and running on. So the trro slaves stood to one side, but would not return, and when the soldiers had passed, they followed them up to the fence of the pa, and stood there firing into it till the soldiers fell back, and afterwards, when the soldiers retreated, they carried off one wounded soldier who had been left behind.

After the fight, the chief of the soldiers sent some people with a white flag to the pa, to ask permission to take away the dead soldiers who lay beside the fence. They were told that they might come and take them next day. Soon after the flag had returned it was night, and then many near friends of Heke came from Kaikohe and entered the pa, for they had heard that the soldiers had been beaten off, and this gave them courage to come, which they had not before, and then late in the night they joining with the men of the pa danced the war dance which is appropriate to victory, and sang the song of triumph as they danced, and the song sounded among the hills in the night like thunder. This was the song-
E tama te uaua,
$\mathrm{E}$ taima te maroro,
Ina hoki ra te tohu!
O youth of sinewy force,
O te uaua.
Kei taku ringa, e mauana.
$\mathrm{O}$ men of martial strength,
Behold the sign of power!
In my hand I hold the scalp,
Te upoko.
Of the Kawau Tatakiha.
O te Kawau Tatakiha!

And often in the night the watch-cry of the pa was 
heard, and this was the cry of the pa-" Come on! come on! soldiers, for revenge, come on! Stiff lie your dead by the fence of my pa-come on, come on!" And also a great shouting and screaming was heard, which the soldiers thought was the cry of one of their men being tortured; but the noise was the voice of a priest who was then possessed of a spirit. But, nevertheless, the body of one soldier was burned that night, for as the people were mending the fence by torchlight there was a dead soldier lying near, and they put a torch of kauri resin on the body to light their work, which burnt the body very much, and caused the report to be spread afterwards, when the body was found by the soldiers, that the man had been tortured; but this was not true, for the man was dead before the fire was thrown on the body.

During the night a report arose amongst the Maori of Walker's camp-I don't know how or from what cause-that the soldiers were about to decamp under cover of darkness, and that the chief of the soldiers had proposed to shoot all his wounded men to prevent them falling alive into the hands of the enemy. When we heard this we got into a state of commotion and great alarm, and did not know what to do. I ran off to a hut where an old pakeha friend of mine slept, and having aroused him, I told him what I had heard, and asked him if such things ever had been done by his countrymen, and also what he thought would be best for us to do. My friend said nothing for some time, but lit his pipe and smoked a little, and at last he said, "Such a thing has never yet been 
done by English soldiers, and be assured will not be done to-night; but, nevertheless, go you to all your relations and those who will listen to your words, and make them watch with their arms in their hands till daylight. I will do the same with my friends, for, perhaps, the soldiers might go to-night to take array the rounded to the Waimate and then return: who knows? And in the morning, perhaps, the enemy may think they are gone away entirely, and may come out of the pa; so, in that case, you and I will elerate our names by fighting them ourselves, without the soldiers." So I and my pakeha friend watched all night with the people, until the sun rose. But the soldiers did not go away that night, so I suppose the report was false, but it alarmed us much at the time, and some of us were very near running away that night. ${ }^{1}$

When the morning came, a party went to bring away the bodies of the dead. The people of the pa had drawn them to a distance from the fence, and left them to be taken away, so they were taken and buried near the camp; and when this was done, the soldiers began to fire on the pa, and the war began again. But the body of the soldier chief who had been killed was not given up, for much of the flesh had been cut off. This was done by the advice of the tohunga, so that the soldiers having been dried for

1 This report actually was really spread in the camp the night after the attack. It struck the natives with consternation, and there are those who still believe that there was some foundation for it, and that a retreat had been talked of. 
food they might lose their mana (prestige, good fortune), and be in consequence less feared.

And the scalp had been taken from the head of Philpots to be used by the tohunga in divination to discover the event of the war. This was not done from revenge or ill-will to him, but because, as he was a toa and a chief, his scalp was more desirable for this purpose than that of an ordinary person.

So the foliage of the battle-field was taken to the Atua Wera that he might perform the usual ceremonies, and cause the people to be fortunate in the war. ${ }^{1}$

When the people in the pa saw that, although the soldiers had lost so many men, they were not dismayed, and seeing also that the inner fence was beginning to give way before the fire of the big gun, they made up their minds to leave the pa in the night, so that the soldiers should not have an opportunity to revenge themselves. So in the night they all left, and went to Kaikohe, without it having been perceived that they were gone.

However, before they had been gone very long, Walker's people began to suspect what had taken

1 Amongst other superstitious native customs, when a battle has been fought, the victorious party send to their priest, no matter how far he may be off, a collection of the herbage actually growing on the field of battle; he takes it and performs with it certain ceremonies, and sends back the messenger with his advice, \&c., \&c. This is called sending the rahu rahu of the battle field. Rahu rahu is the name of the fern which is the most common plant in the North Island. 
place, for the dogs in the deserted pa were howling, and the watch-cry was no longer heard. So a man called Tamahue entered it cautiously, and found it deserted. He crept on softly, and in entering a house he put his hand on a woman who had been left behind asleep, so he kept quiet to see if the sleeping person would awake; and he began to beliere that the people had not left the pa, and was about to kill the sleeping person for utu for himself, for he did not expect to escape alive, there being so many pits and trenches which he could not see in the dark. He, however, thought it would be best first to examine the other houses. This he did, and perceived that the place was deserted, for all the other houses were empty. The only weapon Tamahue had was a tomahawk, for he had lost his left arm at a great battle at Hokianga some years before, and was therefore unable to use a gun. So he returned to the sleeping person, and jumped upon her, and raised his hand to strike, for he did not know it was a woman who was sleeping there, but thought it was a warrior. But though he had but one arm he did not call to his brother, who was close outside the pa, for he intended to strike the first blow in the inside of this fortress himself. You must know that we Maori think this a great thing, even though the blow be struck only against a post or a stone. But Tamahue being naked, as all good warriors should be when on a dangerous adventure, his bare knees pressed against the breast of the sleeping person, and then he perceived it was a woman, so he struck his tomahawk into the ground only, and 
having taken her prisoner, he called his brother, and they returned to the camp, and gave information that the pa was deserted.

Then all at once there arose a great confusion. All the Maori and most of the soldiers ran off to the pa in the dark, and they tumbled by tens into the pits and trenches, which were in the inside of the place. The soldiers ran about searching for plunder, and quarrelling with the Maori for ducks and geese. There was a great noise, every one shouting at once, and as much uproar as if the place had been taken by storm; and so this was how Ohaeawae was taken.

In the morning the soldiers dug up the dead of the enemy, nine in number, being in search of the body of the soldier chief who had been killed in the attack. They found the body and also that of the soldier which had been burned; and besides the nine bodies of the enemy's men which the soldiers dug up, there was also found the body of a woman lying in the pa, which made ten the people of the pa had lost.

While the soldiers were doing this, all the Maori went in pursuit of the enemy as far as Kaikohe; and when they got there a certain pakeha met them, and spoke angrily to the chiefs for pursuing Heke's people, and told us that our souls would be roasted in the other world for making war on Sunday-for it was on Sunday this happened. So the chiefs thought that perhaps it might be unlucky to fight on the ratapu; they, therefore, only set fire to Heke's house at Kaikohe, and returned to the camp at 
Ohaeawae. But before the war was over, we all found that the soldiers did not mind Sunday at all when any harm could be done on it; but when there was nothing else to do they always went to prayers.

After this the soldiers burned the pa, and went back to the Waimate, where they built a fort, and stayed some time, and there they buried Philpots; and we Maori still remember Philpots, for he was a generous, brave, and good-natured man. But now years have gone by, and his ship has sailed awayno one knows where-and he is left by his people; but sometimes a pakeha traveller may be seen standing by his grave. But the Europeans do not lament so loudly as we do; they have perhaps the same thought as some of us, who say that the best lamentation for a toa is a blow struck against the enemy.

While the soldiers were staying at Waimate, Kawiti left Kaikohe, and went to his own place at the Ruapekapeka, and fortified it, making it rery strong; but Heke remained at Tautora, not yet cured of his wound. There was a pa near Waimate, belonging to Te Aratua, and the soldiers went to attack it; but when Te Aratua heard they were coming, he left it, and so the soldiers took it, and burned it, without any opposition.

Some time after this the soldiers left Waimate, and went to the Bay of Islands, where others joined them. The sailors came also in the ships of war, and with them came also the pakeha Maori; and 
there was a great gathering, for the soldiers had heard that the fort of Kawiti at the Ruapekapeka was completely finished and ready for war, and therefore they prepared to attack it. Walker also, and the other chiefs with their people, joined the soldiers as before; and when we were all together we formed a grand war party - the greatest that had been seen during the war. The soldiers forgot nothing this time. They brought with them all their arms of every kind. They brought long and short big guns, and rockets, and guns the shot of which bursts with a great noise. Nothing was left behind. We were glad of this, for we wished to see the full strength of the soldiers put forth, that we might see what the utmost of their power was.'

So this great war party left the Bay of Islands, and went up the river to attack Kawiti at the Ruapekapeka. They went in boats and canoes, and having arrived at the pa of Tamati Pukututu, they landed the guns, and powder, and provisions, and began making a road to the Ruapekapeka. And after many days, the road being completed, the taua advanced, and encamped before the Ruapekapeka.

During the first two days there was not much done, but when all had been got ready, the soldiers began to fire in earnest-rockets, mortars, ship guns,

1 The friendly natives never lost sight of the possibility that they themselves might some day have to fight us. They therefore scrutinized closely all our military proceedings, and were anxious to see us do our very best, or rather, our worst, so that they might know what they would have to contend against. 
long brass guns-all burst out firing at once. We were almost deaf with the noise, and the air was full of cannon balls. The fence of the pa began to disappear like a bank of fog before the morning breeze. So now we saw that the soldiers had at last found out how to knock down a pa. But before the fence was completely broken down, the chief of the soldiers ordered his men to rush up to the pa as they had done before at Ohaeawae. The soldiers were about to do so, for they are a very obedient people, when Moses, with much difficulty, persuaded the chief of the soldiers not to let them go, by telling him that he was only going to waste all his men's lives, and advising him to wait till the fence was entirely gone before he made the attack. We all disliked this soldier very much, and saw that he was a very foolish, inexperienced person, and also that he cared nothing for the lives of his soldiers; but we thought it a great pity to waste such fine well-grown men as the soldiers were, without any chance of revenge.

So the guns fired away, and after a few days the fence was completely down in many places, for the shot came like a shower of hail; but not many were killed in the pa, for they had plenty of houses under ground which the shot could not reach; but they were out of all patience, by reason of the pot guns (mortars). These guns had shot which were hollow exactly like a calabash, and they were full of gunpowder, and they came tumbling into the pa, one after another, and they would hardly be on the ground before they would burst with a great noise; 
and no sooner would one burst than another would burst; and so they came one after another so fast that the people in the pa could get no rest, and were getting quite deaf. These guns, however, never killed any one. They are a very vexatious invention for making people deaf, and preventing them from getting any sleep. One good thing about them is, that, whenever one of the shots does not burst, a considerable number of charges of powder for a musket can be got out of it; and whenever one dropped close to any of the men in the pa, he would pull out the wicki (fuse), and then get out the powder. A good deal of powder was procured in this way.

The pot guns are to make people deaf, and keep them from sleeping; the rockets are to kill people and burn their houses. A rocket knocked off the head of a woman in the pa, but did not hurt a child she had on her back at the time. Another took off the head of a young man of the Kapotai; another took out the stomach of a slave called $\mathrm{Hi}$; he belonged to the Wharepapa chief of the Ihutai. This slave lived till night, crying for some one to shoot him, and then died. One man was killed by a cannon ball which came through the fence and knocked his leg off as easily as if it had been a boiled potato. The man was a warrior of the Ngati Kahununu, from the south; when he saw his leg was off above the knee, he cried out, "Look here, the iron has run away with my leg; what playful creatures these cannon balls are!" When he said this, he fell back and died, smiling, as brave warriors do. 
There was not many killed in the pa, for the people kept under ground; neither did the soldiers lose many men, for they kept at a distance, and let the big guns and rockets do all the work. One erening a strong party rushed out of the pa and attacked Walker's men, and a pretty smart fight ensued. Now, this party were for the most part of the Kapotai tribe, who had killed Hauraki at Waikare, and among Walker's men were several young men, cousins of Hauraki, who had come to seek revenge; and these young men fought with great spirit, and one of them killed Ripiro, a Kapotai, and took his name. ${ }^{1}$ Some others of the Kapotai were killed, and others wounded, but none of Walker's men were killed, and only a few wounded. Amongst the wounded, however, was that brave warrior Wi Repa, who had three fingers of his left hand shot off, being the second time he had been wounded during the war.

By this time the fences of the pa were broken down very much, but the people waited patiently, in expectation that the soldiers would come on to the attack, for they thought that, though the soldiers would take the place, they would be able to kill many of them, and then escape into the forest behind the pa. But the guns and rockets kept firing on, and the people began to be quite tired of hearing the shells bursting all about them continually, when Heke, who

1 It is a common practice when a natire has killed a man of any note in battle, for the party who killed the other to commemorate the exploit by taking the name of the dead man. 
had recovered from his wound, arrived with seventy men. As soon as Heke had observed the state of the pa, and how things were, he said, "You are foolish to remain in this pa to be pounded by cannon balls. Let us leave it. Let the soldiers have it, and we will retire into the forest and draw them after us, where they cannot bring the big guns. The soldiers cannot fight amongst the kareao; they will be as easily killed amongst the canes as if they were woodpigeons." So all the people left the pa except Kawiti, who lingered behind with a few men, being unwilling to leave his fort without fighting at least one battle for it.

The next day after Heke's arrival was Sunday. Most of the soldiers had gone to prayers; many of Heke's people were at prayers also, and no one was in the pa but Kawiti, and a few men who were in the trenches asleep, not expecting to be attacked that day. But William Walker Turau (Walker's brother) thought he perceived that the pa was not well manned, so he crept carefully up to the place and looked in, and saw no one; but Kawiti with eleren men were sleeping in the trenches. Turau then waved his hand to Walker, who was waiting for a signal, and then stepped noiselessly into the fort. Then Walker and Tao Nui with both their tribes came rushing on. The soldiers seeing this left prayers, and with the sailors came rushing into the pa in a great crowd-sailors, soldiers, and Maori all mixed up without any order whatever. When the pa was entered the soldiers set up a great shout, 
which awakening Kawiti, he started up with his eleven men, and saw his pa was taken. How could it be helped? So he and his men fired a volley, and then loaded again, and fired a second rolley, which was as much as he could do. Then they ran away and joined Heke at the rear of the pa, where he called aloud to the Ngapuhi to fight, and not allow his pa to be taken without a battle. ${ }^{1}$

Then the Ngapuhi returned to attack their own pa, which was full of soldiers, and creeping up behind rocks and trees they began to fire, and called out in English, "Never mind the soldiers! Never mind the soldiers!" They did this hoping to enrage the soldiers, and cause them to leave the pa, and follow them into the forest; but most of the soldiers remained in the pa firing through loopholes, for the back of the pa which was now attacked by the Ngapuhi was yet entire, not having been so much broken down by the big guns as the front side had been. A few sailors and soldiers, however, went out at a little gate at the back of the pa, but were no sooner out

1 Kawiti seeing that all the other forts had made so good a defence wished not to abandon his without standing an assault. Heke, however, who was the best general, saw the place would soon become quite untenable from the fire of the artillery, and advised an immediate retreat to the border of the forest; he, however, had great difficulty to get Kawiti, who had a grood deal of the bulldog in him, to retreat. The old chief, howerer, did fire a volley in the inside of the place when the soldiers entered, which he considered saved his honour, as it could not be said he left his fort without fighting. 
than they were shot by the people behind the trees. At last some forty or fifty soldiers got out, and a fight began outside. But Heke and the main body of his men remained at a distance beside the thick forest, in hopes that the party who were fighting the soldiers would soon fall back, and so lead the soldiers to follow them into the forest, where Heke had his ambush prepared for them. But these people did not retire as they should have done, for a report was heard that Kawiti had been killed or taken, and this enraged them so much that they would not retreat, and they remained there trying to retake the pa. But they lost many men, for hundreds were firing at them from loopholes in the pa, besides the soldiers who were close to them outside. Many soldiers were killed or wounded who might have escaped being hurt if they had got behind trees; but these men did not care about covering themselves when they might have done so. The Maori at one time charged, and there was among them a young half-caste; he had in his hand a broad, sharp tomahawk with a long handle, and he rushed upon a sailor, and using both hands he struck him on the neck, and the head fell over the man's shoulders nearly cut off. This was the only man killed by stroke of hand in this fight.

At last Heke sent a man to tell the people to fall back; but they said they would not do so, but would all die there, for Kawiti had been taken. Then the messenger told them that Kawiti was safe and well with Heke, and that he had just seen him; so when they heard this they fell back at once, but the soldiers 
did not follow, being restrained by their different chiefs. So the fight ended, and the Ruapekapeka was taken, and this was the last fight of the war.

There were killed in this fight of Heke's people twenty-three men, and Heke wrote their names in a book, and also the names of all others who had fallen in the war.

How many men the soldiers had killed in the fight I do not know, but I don't think they lost quite so many as the Maori, for most of them were firing through the loopholes of the pa and out of the trenches, and so were well sheltered. One soldier, as I have heard say, was shot by another, because he was going to run away. I don't think it right to do this. When a man feels afraid who is ordinarily of good courage, it is a sign that he will be killed, and he ought to be allowed to go away. It is bad to disregard omens. When a man feels courageous let him fight, and he will be fortunate.

Next day, Heke, Kawiti, and all the people began to consult as to what should be done; for the fort was taken, and they had no provisions, and there was none at any of their other places-all haring been consumed or wasted during the war, and but little had been planted. And the people told the chiefs that they could not live on fern root and fight the soldier's at the same time. They began to say to the chiefs, "Can shadows carry muskets?" They were much perplexed, and some proposed to break up into small parties, and go and live with different tribes who had not taken part in the war, but 
amongst whom they had friends or distant relations. After talking over this plan for some time it was found it would not do, for already some chiefs of distant tribes had said they would give up any one who came to them to the Governor, rather than bring a war against themselves. At last it was proposed to write to the Governor to ask him to make peace. So the letter was written and sent, but no one expected the Governor would make peace so quickly. $\mathrm{He}$, however, consented at once to make peace, and so peace was made, and Heke's people were rery glad indeed. But the chiefs who had been on the side of the soldiers were very sorry, for had the war been continued a little longer, Heke's people would have been starved and scattered, and Walker's people could have taken their land in various places; and, also, after they had been obliged to scatter about the country to obtain subsistence, many would have been taken prisoners, and they never would have had courage to fight agrin.

When Heke saw that peace was sure to be made, he went away to Tautoro, and said he did not want peace to be made, but that if the Governor came to him and asked for peace he would consent. Heke is a man of many thoughts. So Heke kept at a distance at his own place, and never made peace with the Governor or Walker, until Walker at last came to him, and then Heke said that as Walker had come to him there should be peace, but that until the Govenor came also and asked for peace, he would not consider it fully made. 
Well, no one thought that the Governor would go to see Heke, for we think that whoever goes first to the other, is the party who asks for peace. But the Gorernor did go to see Heke, and shook hands with him, but Heke has nerer gone to see the Governor; and now the war is over, and Heke is the greatest man in this Island, and will be Kixg by-and-by. All the Europeans are afraid of him, and give him anything he asks for, or if they refuse he takes it, and no one dare say anything to him.

Great is the courage of the Maori people! You have now heard how they made war against the noble people of England, and were not quite exterminated, as many expected they would be. But Heke, their chief, is a very knowing man; he is learned even in European knowledge. I will tell you how he has become possessed of this knowledge, which enabled him to make war successfully against the soldiers. He has a European friend who has been a very great warrior - a very experienced warrior indeed. It was he who orercame the great soldier of France, Buonaparte, and afterwards in a great sea-fight he defeated and killed the great warchief of England, Wellington. Besides, he gained many other battles by sea and land, and he wrote all his wars in two books. Now, he lent Heke the first of these books to show him how to fight with the soldiers, which is the reason he has been so successful, but if he had had the second book he would have taken Auckland, and been King of New Zealand long ago; but he will get it by-and-by. I never saw this 
book, and Heke never shows it to any one, for he wants to keep all the knowledge to himself. Now, what are you laughing at? It is no use to tell me that Wellington is alive yet. Heke's pakeha killed him long ago-before you were born, perhaps. You are only a young man; what do you know about it? The Wellington you mean is some other Wellington; but the great soldier Wellington, of England, was killed long ago by Heke's pakeha. The Governor is not near so great a man as this friend of Heke's, and is afraid of him. ${ }^{1}$

This has been a great talk. What payment are you going to give me? Give me that bottle of rum. I am so thirsty with talking. Doin't shake your head; I must have it. Oh, how sweet rum is! There is nothing in the whole world so good. I know a pakeha, who says, if I will get him a big pot, and some old gun-barrels, he will show me how to make rum out of corn. Don't take that bottle away. Come, give it me. You are a chief. Give me the

1 Hundreds of natives believed firmly in this absurd story before and during the war. In the present day (1861), when these notes are written, "Young New Zealand" would only langh at it. But formerly this and other equally ridiculous tales were not only believed but had very serious effects. Heke was not the author of the story, but he found it to his hand, added the "books" to it, and turned it to his account. His "pakeha friend" is still extant, as well as the other "pakeha" who endeavoured to prevent Walker's people from taking our part in the war, but they are not by any means such "great men" as in the days when it was believed that one of them was the conqueror of both Wellington and Buonaparte! 
bottle. You are not afraid of the law. I am a great chief; $I$ am not afraid of the law. I will make plenty of rum, and sell it to the pakeha, and get all their money, and I will have a house, and tables, and chairs, and all those sort of things for people to look at; and when the Governor comes to see me, I will scatter money all about the floor, so that when the Governor sees how much more money I have than he has, he will be quite ashamed, and think himself not near so great a chief as I am. I will have fifty pakeha servants, and they shall all work for me one day, and I will make them drunk the next for payment, and the next day they shall work, and the next get drunk, and there shall not be a watch-house in the whole land. ${ }^{1}$

The bottle is empty, get me another. Do now. You are my friend. Give me the key! I will get it myself. You won't! I will break open the door. I will tell the magistrate you have been giving me rum.

1 This convivial scene with my friend the chief is no fiction, but a faithful relation, like everything else in this book, of what actually was said and done. It certainly does not come into the "History of the War," but is inserted just to gire some idea of the state of things in the country districts, and the terms on which tho country settlers manage to exist with their native "friends." The chief's speculation in the distilling line is faithfully giren word for word, as he explained it to me. But it has never come to anything, for although he actually got the "pakeha" to come to his place for the purpose of making "rum" out of corn, when he got him there he pluclied him to such an extent, not leaving him even a blanket on his bed, that he ran for it, and the distillery in consequence came to naught. 
You are a slave. You are all slaves. Your grandfathers have all been put in the watch-house. You are afraid of the magistrate, the magistrate is afraid of the Governor, and the Governor is afraid of Heke. You want to rob us of our country, and to hang us up like dried sharks. You can't. You are not able. You are cowards. You are a coward! Kapai Heke! ${ }^{1}$ (Here exit Ngapuhi chief head-foremost on to the grass-plat before the door, and so ends the history of the war with Heke.)

\section{CONCLUSION.}

Next morning my friend the chief got up, and shook himself into shape, and begged a shirt and a pound of tobacco, neither of which I dare refuse him, and he then took himself off quietly. I have not seen him since, but received a letter from him the other day, beginning with, "Great is my love to you," and ordering me to send him by bearer one red

1 Kapai Heke! tantamount to Vive Heke! In vino veritas-in his cups this stout defender of the pakeha lets out that he in reality is an admirer of Heke, and in another war would probably join him, being, as all the natives are, without any exception, distrustful of the European, and suspecting we intend eventually to rob them of their country. I think their chief reason for this belief is that they themselves would treat us in that way were they able, they being all plunderers and marauders, both by nature and practice, and so "measure our corn in their orvn bushel." 
blanket, and one cloth cap with a gold band, as he is going to Auckland to see the Governor, who he hopes to "talk" a horse and trrenty pounds from, on the strength of his services during the war. Perhaps when he comes back he may tell me all about his journey, and what he said to the Governor, and what the Governor said to him, all of which I will write down in English, as I have this "great talk," which is all I am erer likely to get for my cap and blanket. It is to be hoped the story will be worth the cost. ${ }^{1}$

\section{श2)}

Since the abore was written, I am sorry to say that my old friend has departed this life. He was, with his brother, shot dead some years ago in a scuffle about a piece of land. In justice to the memory of my old and respected friend I am bound to say, that, according to the very best native authorities, his title

1 I am happy to be able to announce to the whole world that my friend the Ngapuhi chief has been to Auckland and returned safe kack, having been extremely well received by the Gorernor. I have also to inform my friends that the chief has told me the whole story of his journey, leaving out nothing; he has told me every word he said to the Governor, and every word the Governor said to him, all of which I hare written in a book for the instruction and improvement of future ages, together with a plan of attack, whereby Auckland would, as he thinks, be taken, sacked, and burned, which this friend of mine made just to wile away the time when not engaged in paying his court to the Governor. I shall, however, reserve this last history till I see what fortune this my wakaka may have. 
to the land was perfectly clear and good. A sense of impartiality, however, forces me also to declare that the title of my other friend who shot him, is also as clear as the sun at noon; there can be no doubt of this. Both have clear undoubted pedigrees, which prove them directly descended from the "original proprietor." The only point of any consequence which made against iny friend's title, was the circumstance of his having been shot dead. This has "made clear," as I am bound to confess, the title of the other party, which now remains without a flaw. The only thing I see against them is the fact that, during the last seven years, their numbers have been much decreased by sickness, while it so happens that the sons of my old friend, and also his brother's sons, have large families of stout, healthy-looking boys. Good native casuists, on whom I can place every reliance, tell me that mas somehow or other affect the title of the others. I don't know clearly how, for though I have studied "native tenure" for thirty years, I find I have even yet made but small progress. Indeed, I have lately begun to suspect that the subject is altogether of too complicated a nature for a European understanding. The only safe maxim I can give on native tenure, after all my study, is as follows:-Every native who is in actual possession of land, must be held to have a good title till some one else shows a better, by kicking him off the premises.

Pakeha Maori. 


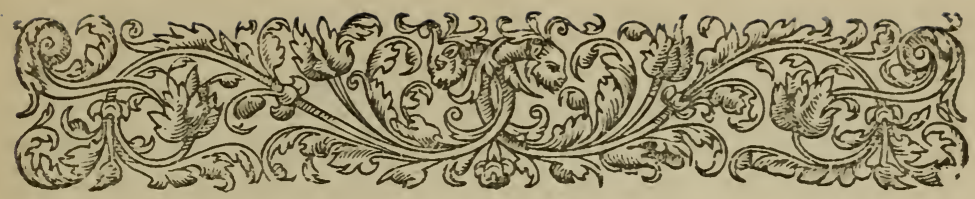

\section{GLOSSARY.}

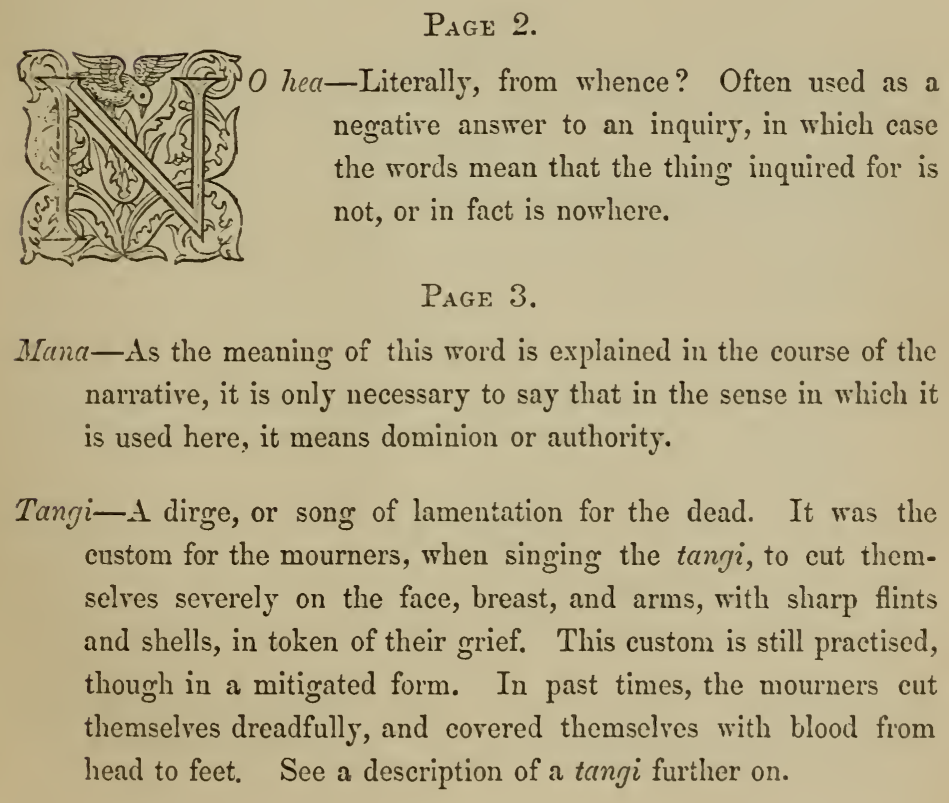

Page 3.

Palicha-An Englishman; a foreigner.

\section{PAGF 10.}

Tupara-A double gun; an article, in the old times, ralued by the natives abore all other earthly riches. 


\section{PAGE 11.}

Hahunga-A hahunga was a funeral ceremony, at which the natives usually assembled in great numbers, and during which " baked meats" were disposed of with far less economy than Hamlet gives us to suppose was observed " in Denmark."

Kainga-A native town, or village: their principal head-quarters.

\section{PAGE 12.}

Haere mai! \&c. - Sufficiently explained as the native call of welcome. It is literally an invitation to advance.

\section{PAge 15.}

Tutua-A low, worthless, and, above all, a poor, fellow-a "nobody."

\section{PAGE 16.}

A pakeha tutua-A mean, poor European.

E aha te pai?-What is the good (or use) of him? Said in contempt.

\section{PAGe 17.}

Rangatira-A chief, a gentleman, a warrior. Rangatira pakeha$\Lambda$ foreigner who is a gentleman (not a tutua, or nobody, as described above), a rich foreigner.

PAGE 18.

Taonga-Goods ; property.

\section{Page 21.}

Mere ponamu-A native weapon made of a rare green stone, and much valued by the natives.

\section{PAGE 22.}

Taniwha-A sea monster; more fulıy described further on. Utu-Revenge, or satisfaction; also payment.

\section{PAGE 26.}

Tino tangata-A " good man," in the language of the prize-ring; a warrior; or literally, a very, or perfect man. 
Page 36.

Taua-A war party; or war expedition.

$\mathrm{P}_{\mathrm{AGE}} 46$.

Tena koutou; or, Tenara ko koutou-The Maori form of salutation, equivalent to our " How do you do?"

\section{PAGE 49.}

$\mathrm{Na}$ ! $\mathrm{Na}$ ! mate rawa!-This is the battle cry by which a warrior proclaims, exultingly and tauntingly, the death of one of the enemy.

\section{PAGE 62.}

Torere.-An unfathomable care, or pit, in the rocky mountains, where the bones of the dead, after remaining a certain time in the first burying place, are removed to and thrown in, and so finally disposed of.

$$
\text { Page SO. }
$$

Eaha mau-What's that to you?

PAGE 130.

Jacky Poto.—Short Jack; or Stumpy Jack.

Page 131.

Tu ngarahu.-This is a muster, or review, made to ascertain the numbers and condition of a native force; generally made before the starting of an expedition. It is, also, often held as a military spectacle, or exhibition, of the force of a tribe when they happen to be visited by strangers of importance: the war dance is gone through on these occasions, and speeches declaratory of war, or welcome, as the case may be, made to the visitors. The "reriew of the Taniwha," witnessed by the Ngati Kuri, was possibly a herd of sea lions, or sea elephants ; animals scarcely ever seen on the coast of that part of New Zealand, and, therefore, from their strange and hideous appearance, at once set down as an army of Taniwha. One man only was, at the defeat of the Ngati Kuri, on Motiti, rescued to tell the tale. 
PAGE 132.

Bare Motiti-The island of Motiti is often called "Motiti wahie kore," as descriptive of the want of timber, or bareness of the island. A more fiercely contested battle, perhaps, was never fought than that on Motiti, in which the Ngati Kuri were destroyed.

Page 149.

Ki au te matcika-I have the mataika. The first man killed in a battle was called the mataika. To kill the mataika, or first man, was counted a very high honour, and the most extraordinary exertions were made to obtain it. The writer once saw a young warrior, when rushing with his tribe against the enemy, rendered almost frantic by perceiving that another section of the tribe would, in spite of all his efforts, be engaged first, and gain the honour of killing the matcitia. In this emergency he, as he rushed on, cut down with a furious blow of his tomaliawk, a sapling which stood in his way, and gave the cry which claims the mataika. After the battle, the circumstances of this question in Maori chivalry having been fully considered by the elder warriors, it was decided that the sapling tree should, in this case, be held to be the true mataika, and that the young man who cut it down should always claim, without question, to have killed, or as the natives say " caught," the matcilia of that battle.

\section{PAGE 152.}

Toa-A warrior of preëminent courage; a hero.

\section{PAGE 171.}

Kia Kotahi ki te ao! Fïa kotahi ki te po!-A close translation would not give the meaning to the English reader. By these words the dying person is conjured to cling to life, but as they are never spoken until the person to whom they are addressed is actually expiring, they seemed to me to contain a horrid mockery, though to the native they no doubt appear the promptings of an affectionate and anxious solicitude. They are also supposed to contain a certain mystical meaning. 


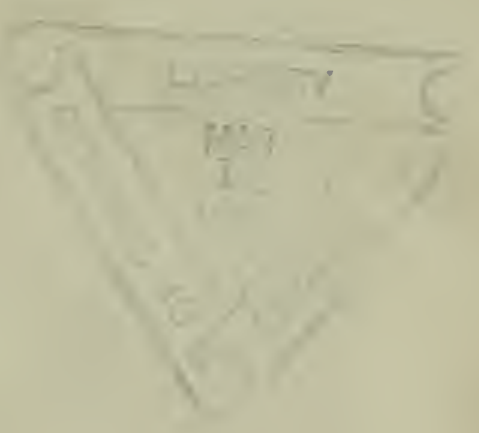




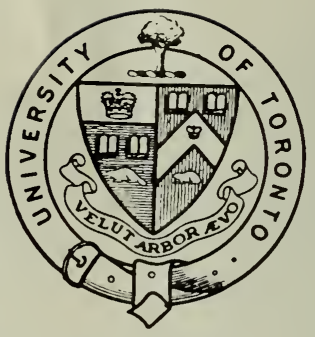

Presented to the

UNIVERSITY OF TORONTO LIBRARY

by the

ONTARIO LEGISLATIVE LIBRARY

$\cdot 1980$ 


\section{PLEASE DO NOT REMOVE CARDS OR SLIPS FROM THIS POCKET}

\section{UNIVERSITY OF TORONTO LIBRARY}




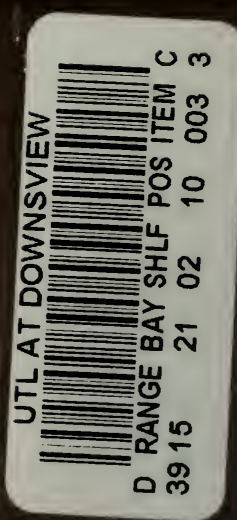

